FERNANDA LUCIO DOS SANTOS

\title{
AVALIAÇÃO DA QUALIDADE E POTENCIAL ATIVIDADE ADJUVANTE DO LIPÍDIO A DE Bordetella pertussis
}

Dissertação apresentada ao Programa de Pós-Graduação Interunidades em Biotecnologia USP/Instituto Butantan/ IPT, para obtenção do Título de Mestre em Biotecnologia. 


\section{AVALIAÇÃO DA QUALIDADE E POTENCIAL ATIVIDADE ADJUVANTE DO LIPÍDIO A DE Bordetella pertussis}

Dissertação apresentada ao Programa de Pós-Graduação Interunidades em Biotecnologia USP/Instituto Butantan/ IPT, para obtenção do Título de Mestre em Biotecnologia.

Área de concentração: Biotecnologia

Orientadora: Dra. Flávia Saldanha Kubrusly

São Paulo

2011 
DADOS DE CATALOGAÇÃO NA PUBLICAÇÃO (CIP)

Serviço de Biblioteca e Informação Biomédica do

Instituto de Ciências Biomédicas da Universidade de São Paulo

(C) reprodução total

\section{Santos, Fernanda Lucio.}

Avaliação da qualidade e potencial atividade adjuvante do Lipídio $\mathrm{A}$ de Bordetella pertussis. / Fernanda Lucio Santos. -- São Paulo, 2011.

Orientador: Prof ${ }^{a}$. Dra. Flávia Saldanha Kubrusly.

Dissertação (Mestrado) - Universidade de São Paulo. Instituto de Ciências Biomédicas. Programa de Pós-Graduação Interunidades em Biotecnologia USP/IPT/Instituto Butantan. Área de concentração: Biotecnologia. Linha de pesquisa: Adjuvantes vacinais.

Versão do título para o inglês: Quality assessment and potential adjuvant activity of Bordetella pertussis Lipid $A$.

Descritores: 1. Adjuvante 2. Lipídio A 3. Bordetella pertussis 4. Lipopolissacarídeo 5. Vacina Hepatite B I. Kubrusly, Prof ${ }^{a}$ Dra. Flávia Saldanha II. Universidade de São Paulo. Instituto de Ciências Biomédicas. Programa de Pós-Graduação em Biotecnologia USP/IPT/Instituto Butantan III. Título. 
Candidato(a): $\quad$ Fernanda Lucio Santos.

Título da Dissertação: $\quad$ Avaliação da qualidade e potencial atividade adjuvante do lipídio A de Bordetella pertussis.

Orientador(a): $\quad$ Prof ${ }^{a}$ Dra. Flávia Saldanha Kubrusly.

A Comissão Julgadora dos trabalhos de Defesa da Dissertação de Mestrado, em sessão pública realizada a ./.................................
( ) Aprovado(a)
( ) Reprovado(a)

Examinador(a): Assinatura:

Nome:

Instituição:

Examinador(a): Assinatura:

Nome:

Instituição:

Presidente: Assinatura:

Nome:

Instituição: 
Aos meus pais, pelo incentivo e dedicação constante para a minha formação...

Ao meu marido André, por ser a luz da minha vida...

À Deus por guiar meus passos e estar sempre ao meu lado... 


\section{AGRADECIMENTOS}

Aos meus amigos e familiares que sempre foram meu apoio durante todos os momentos mais difíceis e nas minhas realizações.

À minha orientadora Dra. Flávia Saldanha Kubrusly, que sempre me ajudou e muito me ensinou nestes três anos.

À Dra. Maria Aparecida Sakauchi, Diretora do Serviço de Bacteriologia, pelo incentivo e carinho dedicado, por sempre ter acreditado em mim, tornando possível a realização deste trabalho.

À Dra. Sally Muller Affonso Prado, Diretora da Divisão de Desenvolvimento Tecnológico e Produção, pelo oportunidade concedida e por acreditar na importância desta formação.

Ao professor Isaias Raw, a mente científica que move e inspira a todos na Instituição.

À Maria Francisca Baltazar Bezerra, pessoa única, que sempre ajudou na realização dos experimentos.

À Milena Apetito Akamatsu e Elaine Darini, por compreenderem a minha angústia nos momentos finais deste trabalho.

Ao Dmitri lourtov, pelo auxílio nas formulações e aos alunos do Centro de Biotecnologia pelo colaboração e companherismo.

À Dra. Elisabete Tenório, Diretora do Serviço de Virologia, pela colaboração no ensaio com a vacina recombinante contra Hepatite $B$.

Aos funcionários da Seção de Controle Biológico, pela colaboração nos ensaios in vivo.

Aos funcionários do Serviço de Controle de Qualidade, especialmente o Dr. Wagner Quintilio pelas sugestões na realização dos ensaios in vitro.

À Nilza da Seção de Controle Físico-Químico, pelo auxílio na execução dos testes de controle de processo. 
Ao Dr. José Amaral do Prado, pela colaboração na liofilização dos produtos.

À Profa. Dra. Iolanda Midea Cuccovia do Laboratório de Biomiméticos do Departamento de Bioquímica IQ/USP, pelo auxílio na realização dos testes com as emulsões.

Aos amigos da Seção de Vacinas Aeróbicas pelo auxílio e compreensão durante a realização deste trabalho.

À Fundação Butantan pelo apoio financeiro. 
"A única felicidade da vida está na consciência de ter realizado algo de útil em benefício da humanidade..." 


\section{RESUMO}

SANTOS, F. L. Avaliação da qualidade e potencial atividade adjuvante do Lipídio A de Bordetella pertussis. 2011. 99 f. Dissertação (Mestrado em Biotecnologia) - Instituto de Ciências Biomédicas, Universidade de São Paulo, São Paulo, 2011.

Atualmente várias substâncias estão sendo avaliadas quanto à sua possível atividade adjuvante, apresentando alta potência, mas também alta toxicidade, que os impede de serem introduzidos numa rotina clínica, como o lipopolissacarídio (LPS), componente da parede celular das bactérias Gram negativas. A função do LPS de B. pertussis como um adjuvante torna-se evidente pelo aumento da produção de anticorpos quando este LPS é co-administrado durante a vacinação. Estudos têm estimulado o desenvolvimento de derivados de LPS com propriedades potencialmente úteis, um dos exemplos mais conhecidos é o monofosforil lipídio $\mathrm{A}$ (MPL), que foi desenvolvido como adjuvante para a aplicação em vacinas de uso humano. O objetivo deste estudo foi caracterizar um sub-produto do LPS de Bordetella pertussis (BpLipídioA), através do desenvolvimento e padronização de testes de controle de qualidade, visando a posterior utilização deste sub-produto como adjuvante vacinal. Este produto é obtido por extração orgânica de um concentrado de células de Bordetella pertussis, com posterior hidrólise ácida em alta temperatura, sendo submetido à testes de controle de qualidade que caracterizam suas propriedades fisico-químicas, biológicas e estruturais. O conhecimento adquirido sobre o produto durante as fases de pesquisa e desenvolvimento conduziu à seleção de testes físico-químicos, biológicos e microbiológicos, bem como sua faixa de aceitação e limites de deteç̧ão. A atividade adjuvante deste produto foi realizada com a Vacina de Hepatite $B$ Recombinante e apresentou resultados promissores. O BpLipídioA foi formulado em emulsão óleo em água, onde foi verificada a estabilidade deste composto. A utilização deste produto em emulsão ou suspensão apresentou-se possível e permite a redução da quantidade de antígeno na dose vacinal, o que aumenta a capacidade de produção das vacinas.

Palavras-chave: Adjuvante. Lipídio A. Bordetella pertussis. LPS. Vacina Recombinante contra Hepatite B. 


\begin{abstract}
SANTOS, F. L. Quality assessment and potential adjuvant activity of Bordetella pertussis Lipid A. 2011. 99 p. Masters Thesis (Biotecnology) - Instituto de Ciências Biomédicas, Universidade de São Paulo, São Paulo, 2011.

Currently a number of substances are being evaluated for possible adjuvant activity, with high power but also high toxicity, which prevents them from being introduced into clinical routine, such as lipopolysaccharide (LPS), cell wall component of Gram negative bacteria. The role of $B$. pertussis LPS as an adjuvant is evident by the increased production of antibodies when the LPS is co-administered during vaccination. Studies have stimulated the development of derivatives of LPS with potentially useful, one of the best known examples is the monophosphoryl lipid A (MPL), which was developed as an adjuvant for use in human vaccines. The aim of this study was to characterize a byproduct of Bordetella pertussis LPS (BpLipídioA), through the development and standardization of quality control tests in order to later use this sub-product as an adjuvant vaccine. This product is obtained by LPS organic extraction of $B$. pertussis cells with subsequent acid hydrolysis at high temperature and subjected to quality control tests that characterize their physico-chemical, biological and structural features. The knowledge about the product during all phases of research and development led to the selection of optimal physico-chemical, biological and microbiological tests as well as its acceptable range and detection limits. The adjuvant activity of this product was performed with the recombinant hepatitis B vaccine, which showed promissory results. The BpLipídioA was formulated in oil-water emulsion and its stability checked. Using this product in emulsion or suspension forms had to be possible to reduce the amount of antigen in the vaccine dose, which increases the installed production capacity of vaccines.
\end{abstract}

Key words: Adjuvant. Lipid A. Bordetella pertussis. LPS. Recombinant Hepatitis B Vaccine. 


\section{LISTA DE FIGURAS}

Figura 1. Número de casos de doenças infecciosas, período pré-vacinação e pósvacinação, com a introdução das campanhas vacinais. O caso mais expressivo ocorreu na difteria, com uma redução de $99,99 \%$ do número de casos .23

Figura 2. Representação esquemática da estrutura química do LPS bacteriano. GlcN - glucosamina; Kdo - ácido 2-keto-3-deoxioctonato; Hep - L-glicerol-D-mannoheptose; P - fosfato; EtN - etanolamina; ${ }^{\mathbb{X}}$ ácidos graxos.

Figura 3. Estruturas do lipídio A de diferentes espécies de Bordetella, evidenciando as diferenças no número de cadeias de ácidos graxos.

Figura 4. Análise estrutural do LPS purificado de B. pertussis por ESI-MS. (A) Espécies iônicas: 1251, 1307.3, 1477.3, 1557.3 m/z. (B) 1251.5, 1307.4, 1477.7, $1505.6 \mathrm{~m} / \mathrm{z}$. (C) $1251.6,1307.8,1477.1,1557.3 \mathrm{~m} / \mathrm{z}$. 35

Figura 5. Fluxograma de produção do lipídio $A$ de Bordetella pertussis, o Lipídio A de Bordetella pertussis é obtido à partir da destoxificação da vacina pertussis celular por extração orgânica do LPS, que é submetido à hidrólise ácida, seguido por neutralização com hidróxido de amônio. O produto então é resfriado, envasado e liofilizado. Testes realizados para caracterização do produto e avaliação da qualidade e reprodutibilidade dos diferentes Lotes 43

Figura 6. Representação esquemática das metodologias aplicadas para a dosagem de KDO. 46

Figura 7. Esquema da placa de sílica para o teste com os pontos de aplicação das amostras. 48

Figura 8. Câmara de corrida e placas de sílica. 48 
Figura 9. Etapas de preparo da emulsão IB. Testes para controle do processo realizados nas emulsões.

Figura 10. Atividade do lipídio $A$ hexacilado e de um lipídio $A$ hidrolizado com menor número de cadeias aciladas 59

Figura 11. Espectrometria de massa de um lote de BpLipídioA com alteração de metodologia para obtenção de espécies pentaaciladas. 60

Figura 12. Fração PS-II com a molécula de KDO fosforilada (retângulo vermelho) e fração lipídica 63

Figura 13. Espectros de massa do Lipídio $A$ e do lipooligossacarídio (LOS) de Bordetella. Os painéis A e B mostram os espectros do lipídio $A$ de B. pertussis, linhagens 338 e 18-323, respectivamente; apresentando espécies tetra (4FA) e pentaaciladas (5FA). Painéis C e D descrevem os espectros de LOS. Painel E apresenta estruturas pentaaciladas com incorporações de uma ou mais glicosaminas (esquerda) ou de estruturas sem incorporação de glicosamina mas que apresentam na posição C-3 do arcabouço das duas glicosaminas cadeias aciladas hidroxiladas de 12 ou 10 carbonos no lugar de 14 65

Figura 14. Análise da abundância relativa das espécies iônicas predominantes e dos fragmentos de LOS nos 7 lotes analisados. 66

Figura 15. Intensidade das principais espécies iônicas dos 7 lotes analisados 68

Figura 16. Perfil da espectrometria de massa do lipídio A de Bordetella pertussis obtido por diferentes metodologias. (A) hidrólise por ácido butírico e hidróxido de amônio, (B) hidrólise com SDS e pH de 4,5 e (C) hidrólise com ácido acético 69

Figura 17. Espectro de massa do Lipídio A de Bordetella pertussis obtido por hidrólise ácida com predominância de espécies tri, tetra e pentaciladas. 69

Figura 18: Abundância relativa das espécies iônicas dos 7 lotes analisados 70 
Figura 19: (I) TLC do LPS e Lipídio A de B.pertussis (A) 1. LPS; 2. Lipídio A bruto (método alcalino); 3. Lipídio $A$ bruto (método $0,25 \mathrm{~N}$ de $\mathrm{HCl}$ ); 4. Lipídio $A$ purificado (método alcalino); 5. Lipídio A purificado (método $0,25 \mathrm{~N} \mathrm{HCl}$ ) 6. Lipídio A homogêneo (método $0,25 \mathrm{~N} \mathrm{HCl}$ ) (TLC preparativa) (Figura extraída de CAROFF et al., 1986). (II) TLC apresentando espécies moleculares identificadas pelas massas correspondentes. 71

Figura 20: (I) Perfil dos lotes produzidos de BpLipídioA. Sistema de solventes: clorofórmio/metanol/água/trietilamina 3:1,5:0,25:0,1 (CAROFF et al., 1988, TIRSOAGA et al., 2007). Padrão LpA: Lote padrão de BpLipídioA com espécie iônica de $\mathrm{m} / \mathrm{z}$ 1586. FM: LPS extraído de Bordetella pertussis e os 7 lotes de LpA analisados, sendo o 1/LpA dividido em 3 sub-lotes: $1 / \mathrm{LpA}^{*}$ sub-lote $1 ; 2 / \mathrm{Lp} A^{\star *}$ sublote $2,1 / L p A^{* * *}$ sub-lote 3 , sendo esta divisão devido à liofilização de cada um dos lotes, que foi realizada separadamente. (II) TLC de Lipídio A isolado de B.pertussis; (A) Lipídio A isolado; (B) componente minoritário isolado; (C) componente majoritário isolado .72

Figura 21: Variação de temperatura no teste de pirogênio in vivo dos lotes amostrados. A análise de tendência demonstrou que houve um aumento de temperatura nos animais inoculados com os últimos lotes produzidos: 6/LpA e 7/LpA 76

Figura 22: Variação de peso em (g) do grupo inoculado com relação ao grupo controle . .77

Figura 23: Porcentagem da variação de peso dos animais inoculados com o lote 1/LpA. O grupo de animais inoculados com o produto, apresentou ganho de peso de $69,3 \mathrm{~g}$ na somatória geral e o grupo controle 72,3 g, ambos acima do limite mínimo de variação, que representa os $60 \%$ de ganho de peso do grupo controle 
Figura 24: Porcentagem da variação de peso dos animais inoculados com os lotes 2/LpA e 3/LpA. Os grupos de animais inoculados com o produto apresentaram ganho de peso de 70,0 g e 59,5 g sendo que o grupo controle apresentou ganho de peso de $68,0 \mathrm{~g}$, ambos lotes tiveram valores acima do limite mínimo de variação, que representa os $60 \%$ de ganho de peso do grupo controle.

Figura 25: Porcentagem da variação de peso dos animais inoculados com os lotes 4/LpA, 5/LpA, 6/LpA e 7/LpA. Os grupos de animais inoculados com o produto apresentaram ganho de peso de 108,8 g, 152,1 g, 119,9 g, 119,3 g sendo que o grupo controle apresentou ganho de peso de $141,3 \mathrm{~g}$, todos os lotes apresentaram valores acima do limite mínimo de variação, que representa os $60 \%$ de ganho de peso do grupo controle.

Figura 26: Título de anticorpo anti-HBs obtido por imunoensaio do tipo ELISA após 30 dias da inoculação dos animais com as diferentes formulações vacinais. (VHB Ref) Vacina de Hepatite B Referência; (VHB) Lote de Vacina de Hepatite B recombinante; (1) rHBsAg 0,625 $\mu \mathrm{g} /$ dose; (2) rHBsAg 0,625 $\mu \mathrm{g} / \mathrm{dose}+\mathrm{Al}(\mathrm{OH})_{3}$; (3) rHBsAg 0,312 $\mu \mathrm{g} /$ dose $+\mathrm{Al}(\mathrm{OH})_{3}+$ BpLipídioA $10 \mu \mathrm{g} / \mathrm{dose}$; (4) rHBsAg 0,312 $\mu \mathrm{g} /$ dose + BpLipídioA $10 \mu \mathrm{g} /$ dose; (5) BpLipídioA $10 \mu \mathrm{g} /$ dose; (6) controle.

Figura 27: Gráfico de distribuição das partículas com relação ao seu tamanho e intensidade, (I) primeira análise após o preparo da emulsão e (II) segunda análise após 6 meses de preparo da emulsão de $100 \mu \mathrm{g} / \mathrm{mL}$, demonstrando que não houve alteração na intensidade ou tamanho das partículas .87

Figura 28: Gráfico de distribuição das partículas com relação ao seu tamanho e intensidade, (I) primeira análise após o preparo da emulsão e (II) segunda análise após 6 meses de preparo da emulsão de $20 \mu \mathrm{g} / \mathrm{mL}$, demonstrando que houve uma variação de $91,28 \mathrm{~nm}$ para 105,7 nm, que não foi considerada significativa, pois ainda é metaestável, apresentando um crescimento em torno de $15 \%$ no tamanho da partícula. 


\section{LISTA DE TABELAS}

Tabela 1 - Tipos de adjuvantes 30

Tabela 2 - Lipídio A Destoxificado de Salmonella minnesota. Resultados analíticos típicos

Tabela 3 - Curva padrão para dosagem de proteína com concentrações variando entre $10 \mu \mathrm{g}$ a $640 \mu \mathrm{g}$ de BSA.

Tabela 4 - Esquema das diluições para determinação de um limite de detecção de acetato de amônio 49

Tabela 5 - Esquema das formulações vacinais a serem testadas quanto a sua atividade imunogênica. Cada uma das formulações foi preparada com o volume de $5 \mathrm{~mL}$ .56

Tabela 6 - Resultados dos testes de endotoxina bacteriana para os 7 lotes analisados.

Tabela 7 - Resultado da dosagem de KDO pela técnica com reativo de Purpald ${ }^{\circledR}$, quantificando resíduos de KDO no produto final.

Tabela 8 - Valores da dosagem de KDO quantificando de maneira indireta o LPS presente na matéria-prima que será utilizada na produção do BpLpA.

Tabela 9 - Resultados da dosagem de fósforo de todos os lotes. .64

Tabela 10 - Resultados da dosagem de proteína, concentração e porcentagem relativa no produto final.

Tabela 11 - Representação das 5 espécies iônicas predominantes nos lotes analisados, dentro da faixa de $\mathrm{m} / \mathrm{z}$ de 1000 a 2000. 
Tabela 12 - Teste de esterilidade de todos os lotes amostrados .73

Tabela 13 - Valores de pH de todos os lotes amostrados, apresentando variação entre 6,0 e 6,6 .

Tabela 14 - Resultado da variação de peso dos camundongos inoculados com o produto e a solução controle durante o teste de inocuidade. .78

Tabela 15 - Variação de peso dos camundongos inoculados com o produto e com a solução controle durante o teste de toxicidade específica. 80

Tabela 16 - Análise estatística do título de anticorpos anti-HBsAg obtida pelo programa 1way ANOVA. 84

Tabela 17 - Testes de controle de processo e toxicidade realizados nas emulsões formuladas com as concentrações de $20 \mu \mathrm{g} / \mathrm{mL}, 100 \mu \mathrm{g} / \mathrm{mL}$ e $400 \mu \mathrm{g} / \mathrm{mL}$. 85

Tabela 18 - Resultado do ganho de peso dos animais durante o teste de inocuidade. Os animais do grupo controle, inoculados com solução fisiológica apresentaram ganho de peso de $16,4 \mathrm{~g}$ 85

Tabela 19 - Análise da estabilidade das emulsões durante 6 meses de armazenamento em temperatura de 2 a $8^{\circ} \mathrm{C}$. 86 


\section{LISTA DE ABREVIATURAS E SIGLAS}

APC - Célula apresentadora de antígeno

APCI - Ionização química em pressão atmosférica

BpLipídioA - Lipídio A de Bordetella pertussis

BpMPLA - Monofosforil Lipídio A de Bordetella pertussis

BSA - Soro albumina bovina

CFA - Adjuvante de Freund Completo

CTL - Linfócito T citotóxico

DLS - Dispersão dinâmica da luz

DMSO - Dimetil sulfóxido

DO - Densidade óptica

DTP - Vacina Tríplice (Difteria, Tétano e Pertussis)

DTPa - Vacina Tríplice (Difteria, Tétano e Pertussis Acelular)

DTPL - Vacina Tríplice Low (Difteria, Tétano e Coqueluche)

ELISA - Enzyme Linked Immunosorbent Assay

ESI - lonização por "electrospray"

ESI-MS - Espectrometria de massa por ionização em "electrospray"

FDA - Food and Drug Administration

FM - Filtrado LPS

HB - Hepatite B

HBsAg - Antígeno recombinante contra Hepatite B

HPLC - Cromatografia líquida da alta performance

IFA - Adjuvante de Freund Incompleto

KDO - 2-keto-3-deoxyoctonate

LAL - Limulus Amebocyte Lysate

LOS - Ligooligossacáride

LpA - Lipídio A de Bordetella pertussis

LPS - Lipopolissacarídeo

MHC - Complexo Principal de Histocompatibilidade

MPL - Monofosforil Lipídio A

MWG - "Weight gain test" (teste de ganho de peso)

PAMPs - Padrões moleculares associados à patógenos

TBA - Ácido tiobarbitúrico 
TLC - Cromatografia de camada delgada

TLR - Receptor do tipo "Toll"

UE - Unidades endotóxicas

VPa - Vacina Pertussis Acelular

VPL - Vacina Pertussis Low 


\section{LISTA DE FÓRMULAS}

$\begin{array}{ll}\text { Fórmula Molecular } & \text { Nome Químico } \\ \mathrm{H}_{2} \mathrm{SO}_{4} & \text { Ácido Sulfúrico } \\ \mathrm{HIO}_{4} & \text { Ácido Periódico } \\ \mathrm{NaAsO} \mathrm{S}_{2} & \text { Arsenito De Sódio } \\ \mathrm{HCl} & \text { Ácido Clorídrico } \\ \mathrm{CHCl} & \text { Clorofórmio } \\ \mathrm{CH}_{3} \mathrm{OH} & \text { Metanol } \\ \mathrm{C}_{2} \mathrm{H}_{6} \mathrm{O}_{5} & \text { Dimetil Sulfóxido } \\ \mathrm{N}_{\left(\mathrm{CH}_{2} \mathrm{CH}_{3}\right)_{3}} & \text { Trietilamina } \\ \mathrm{NalO}_{4} & \text { Metaperiodato De Sódio } \\ \left(\mathrm{NH}_{4}\right)_{6} \mathrm{Mo}_{7} \mathrm{O}_{24} \cdot 4 \mathrm{H}_{2} \mathrm{O} & \text { Molibdato De Amônio } \\ \mathrm{HClO}_{4} & \text { Ácido Perclórico } \\ \mathrm{C}_{4} \mathrm{H}_{10} \mathrm{O} & \text { Álcool N-Butílico } \\ \mathrm{KH}_{2} \mathrm{PO}_{4} & \text { Fosfato De Potássio Monobásico } \\ \mathrm{C}_{6} \mathrm{H}_{8} \mathrm{O}_{6} & \text { Ácido Ascórbido }\end{array}$




\section{SUMÁRIO}

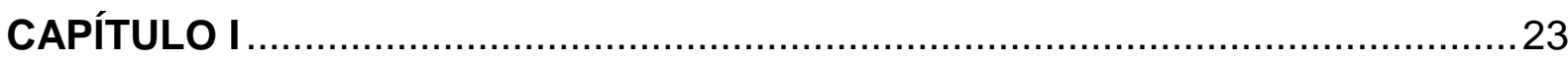

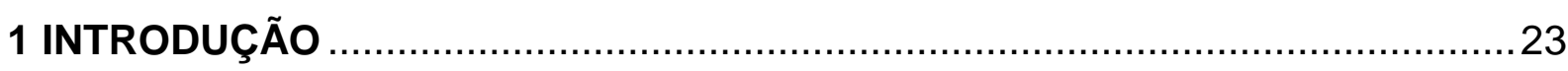

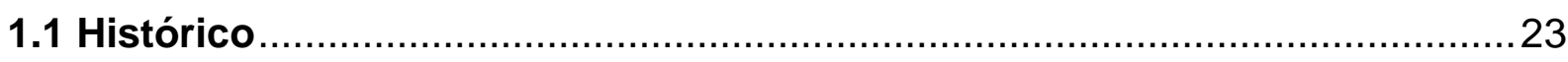

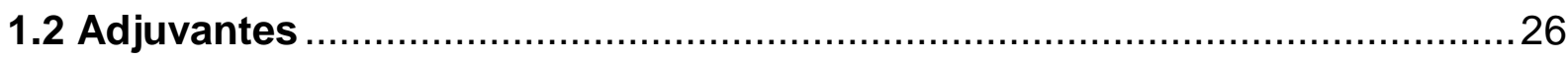

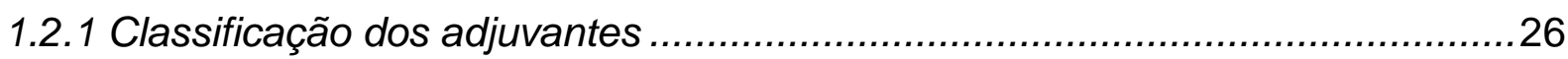

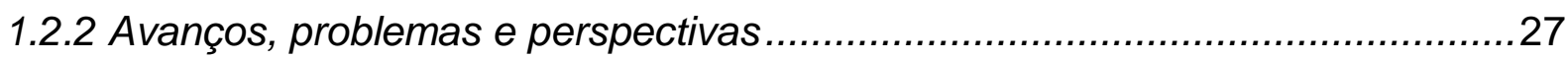

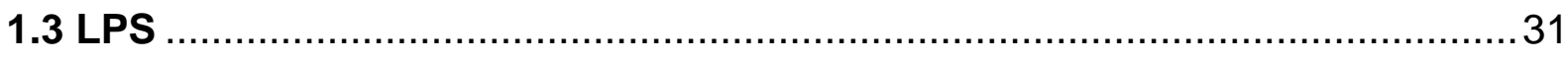

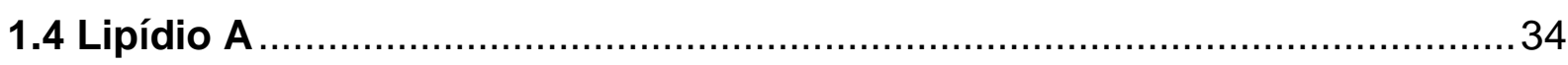

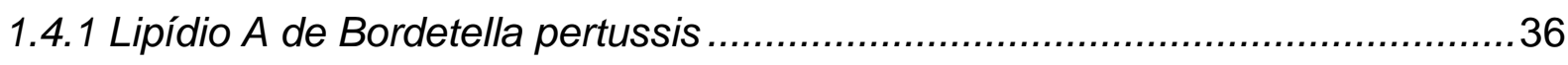

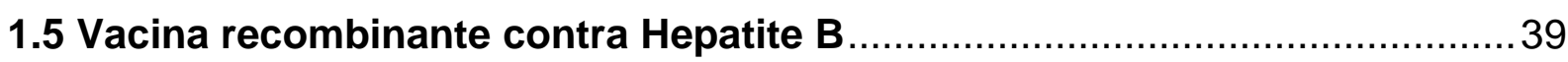

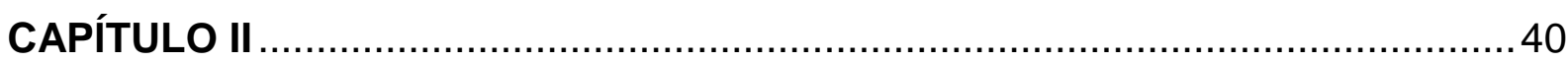

2 OBJETIVOS

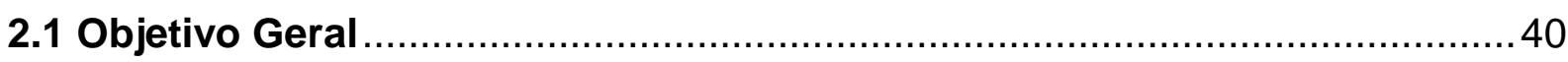

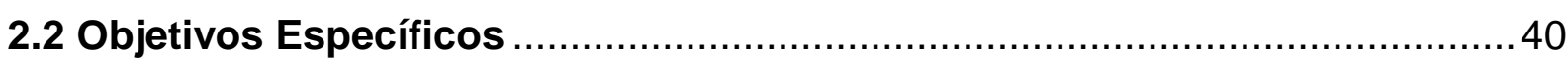

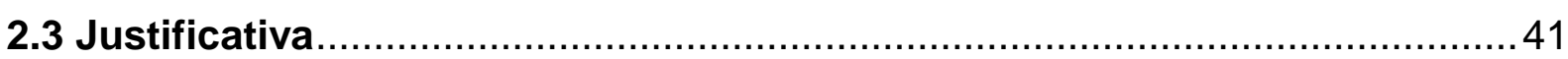

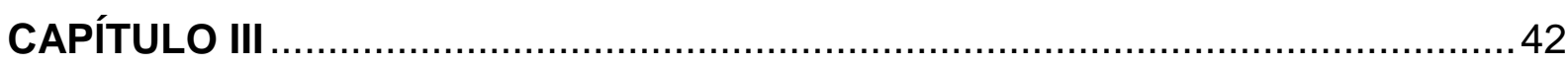

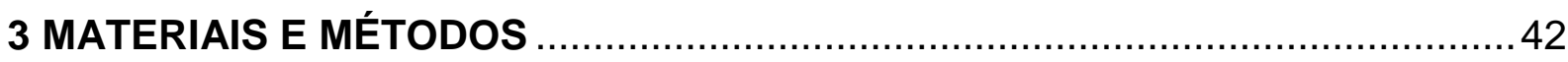

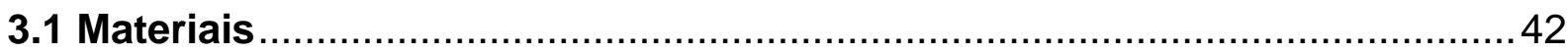

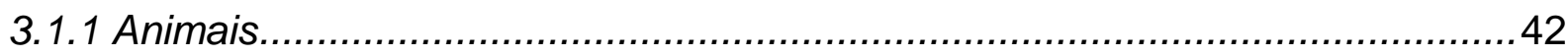

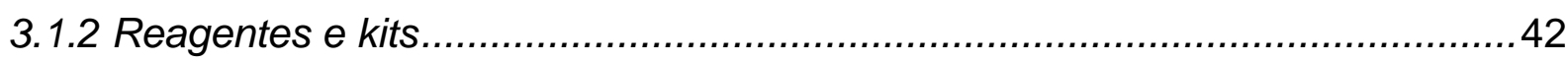

3.1.3 Equipamentos, acessórios e materiais de consumo ……............................ 42

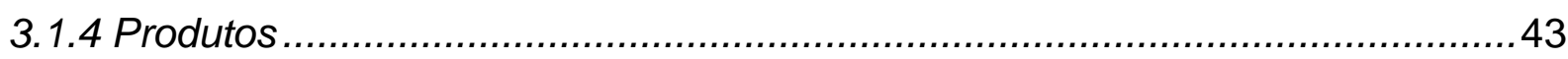

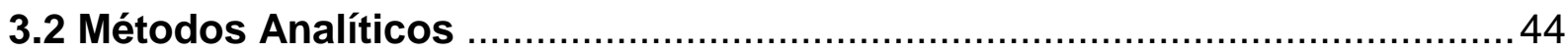

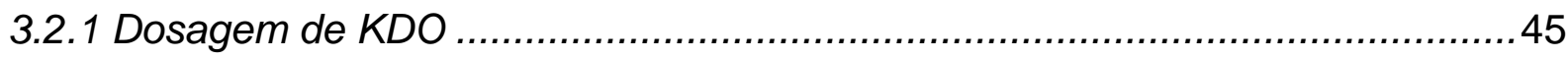

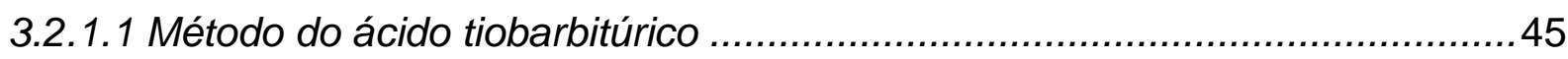

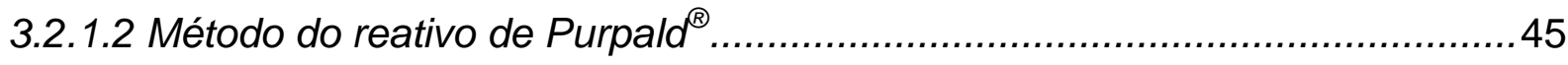

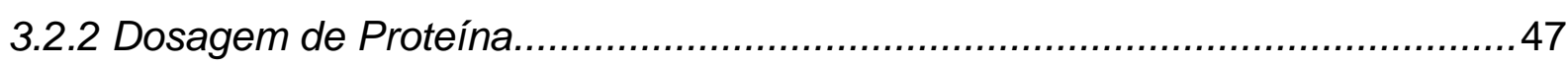

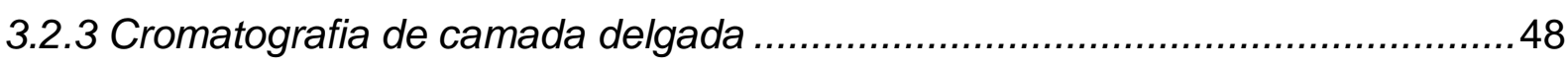

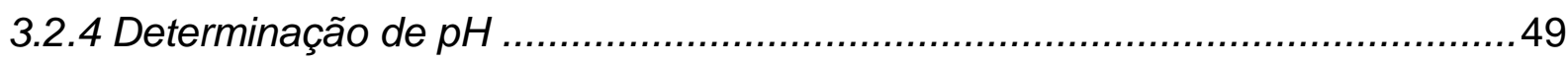


3.2.5 Teor de amônia residual..................................................................... 49

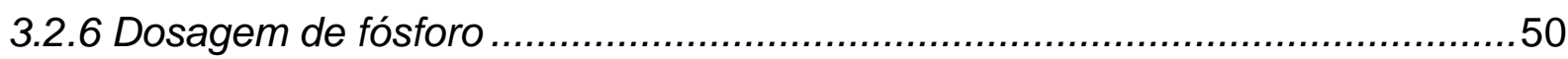

3.2.7 Espectrometria de massa ............................................................. 51

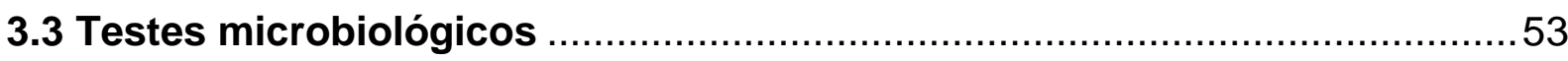

3.3.1 Teste de esterilidade bacteriana e fúngica ...............................................53

3.3.2 Teste de endotoxina bacteriana - pirogênio in vitro $(L A L)$..............................53

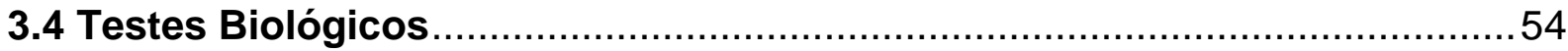

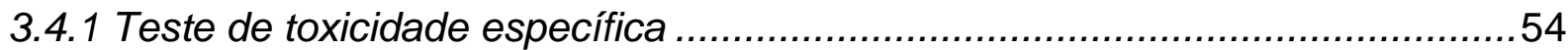

3.4.2 Teste de toxicidade inespecífica (inocuidade)..........................................54

3.4.3 Teste de pirogênio in vivo............................................................ 54

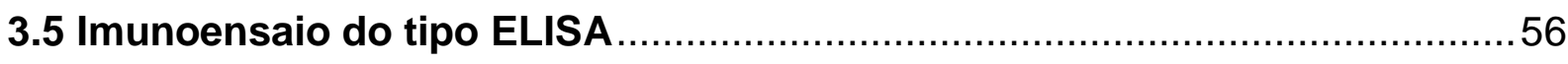

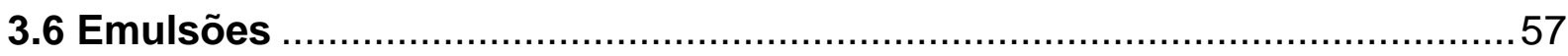

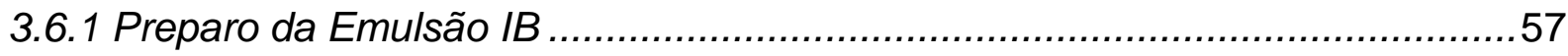

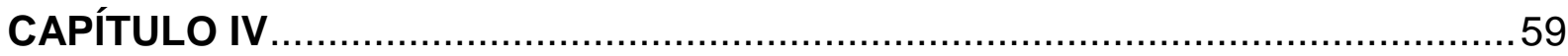

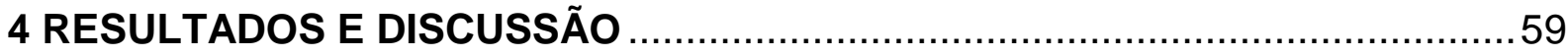

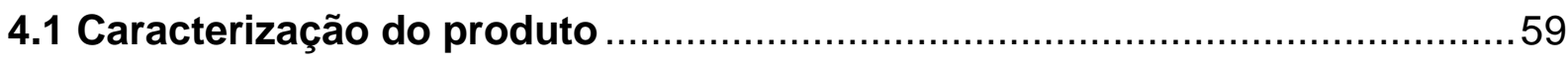

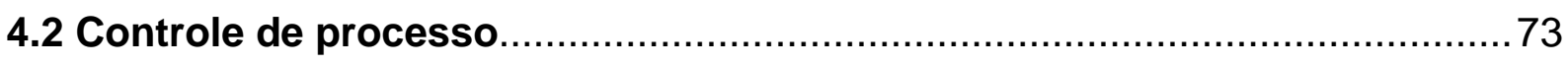

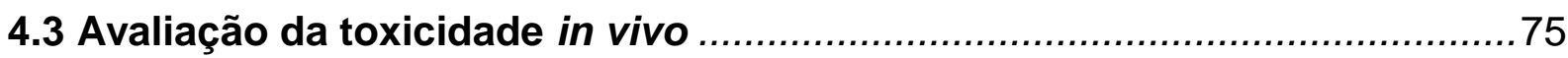

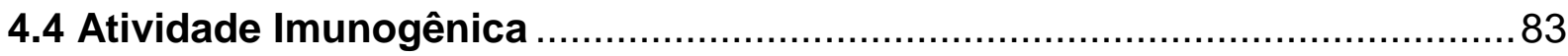

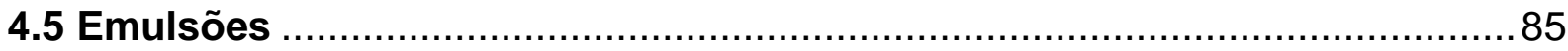

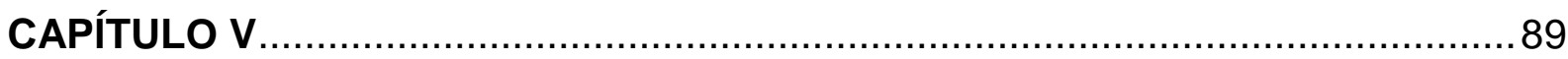

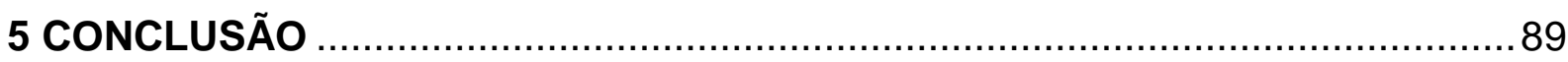

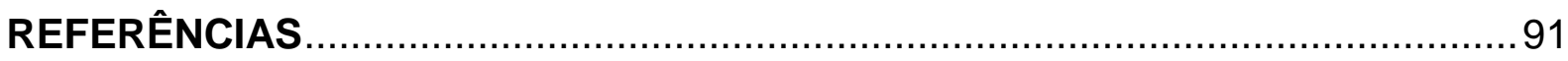




\section{CAPÍTULO I}

\section{INTRODUÇÃO}

\subsection{Histórico}

Embora a primeira investigação científica para prevenção da varíola tenha sido conduzida por Edward Jenner em 1796 e a ele seja creditado o início da vacinação moderna, muito dos primeiros esforços para vacinar indivíduos ocorreu antes do século XVI na China, ou em casos como o do fazendeiro Benjamin Justy que inoculou sua família com pus de varíola bovina para prevenir a varíola humana, e são relatados bem antes de Edward Jenner (HILLEMAN, 2000; ESSER et al., 2003).

Desde a invenção da vacina contra varíola, formulações vacinais representam a estratégia com melhor custo benefício para o controle profilático de doenças infecciosas (Figura 1). Muitas doenças responsáveis por milhões de óbitos no passado (sobretudo entre crianças e idosos) estão hoje erradicadas, como a varíola, ou em vias de desaparecer, como a poliomielite, o sarampo, a coqueluche, a difteria, entre outras, como consequência direta da descoberta, produção e aplicação generalizada de vacinas. No entanto, o problema das doenças infecciosas ainda persiste e representa uma ameaça real para toda a humanidade.
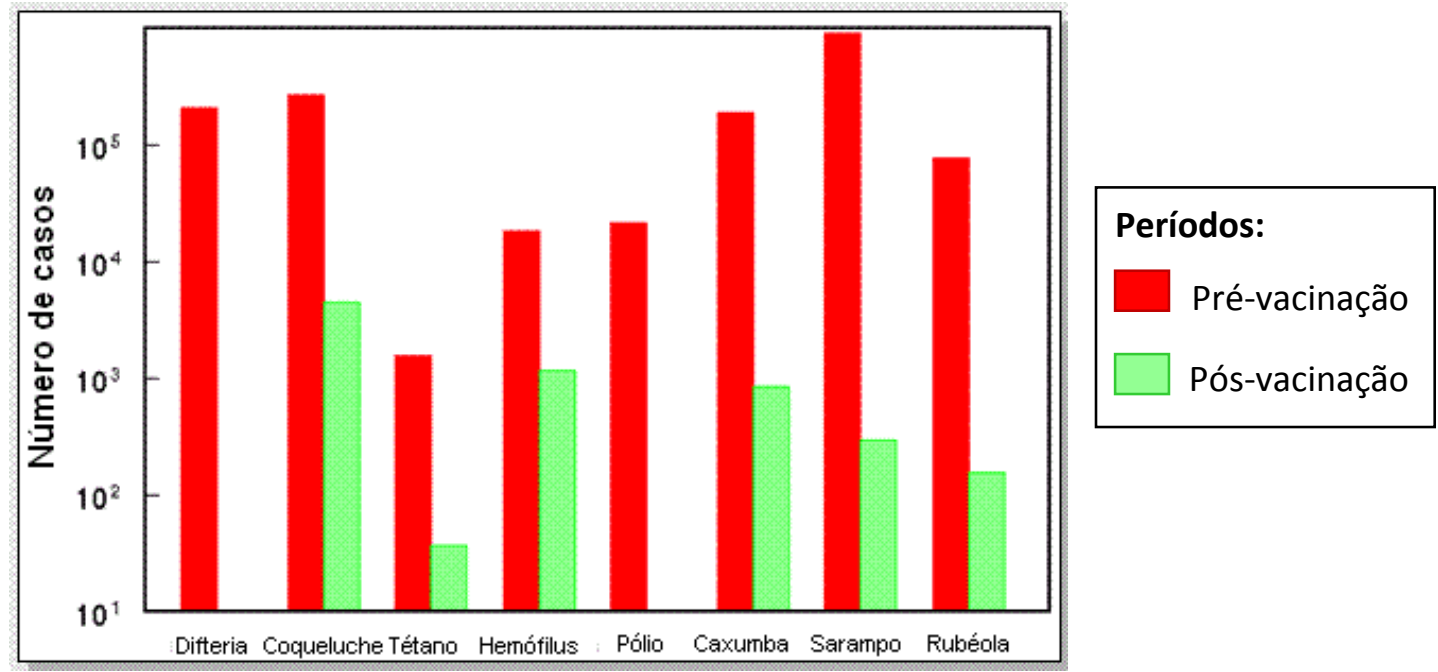

Figura 1: Número de casos de doenças infecciosas, $\square$ período pré-vacinação e $\square$ pós-vacinação, com a introdução das campanhas vacinais. O caso mais expressivo ocorreu na difteria, com uma redução de $99,99 \%$ do número de casos Fonte: Hopkins (2009). 
Atualmente, entre os maiores desafios no campo da vacinologia incluem-se o desenvolvimento de vacinas com propriedades terapêuticas e a busca por novos adjuvantes, eficazes e seguros para emprego em animais e humanos (BIANCHI et al., 2007).

O sistema imune inato é capaz de reconhecer porções antigênicas presentes na superfície de patógenos, conhecidas como PAMPs (padrões moleculares associados à patógenos). O objetivo da formulação vacinal é apresentar esses antígenos ao organismo, de maneira inofensiva e controlada, para geração de resposta imune adequada e duradoura (BIANCHI et al., 2007).

Vacinas baseadas em microganismos vivos são em geral imunogênicas, entretanto, o risco de reversão parcial ou total de virulência tem encorajado o emprego de proteínas purificadas como antígenos vacinais. Embora mais seguras, as vacinas de subunidades são pouco imunogênicas, gerando uma fraca resposta imune, associada principalmente à natureza das moléculas utilizadas, em geral, proteínas recombinantes. Nesse contexto surge a necessidade do uso de adjuvantes vacinais, que são substâncias capazes de aumentar ou modular a resposta imune a um determinado antígeno, que vêm sendo estudadas desde o início do século passado (DOUGAN; HORMAECHE, 2006).

O aumento do interesse em adjuvantes nas últimas duas décadas ocorreu em paralelo às novas tendências no desenvolvimento de vacinas, incluindo as vacinas compostas de subunidades e antígenos sintéticos, vacinas para indicações terapêuticas, e vacinas destinadas a estimular a imunidade da mucosa. É claro que o sucesso destas novas oportunidades contará com a utilização de adjuvantes que medeiam e promovem a indução de uma vasta gama de diferentes respostas imunes. Por exemplo, formulações com subunidades vacinais e vacinas sintéticas com um mínimo de epítopos antigênicos, são frequentemente pouco imunogênicas e promovem uma resposta imune insuficiente ou inadequada, sendo assim, os adjuvantes são necessários para melhorar e direcionar a resposta do sistema imunitário para o tipo de proteção encontrada na sequência de uma infecção natural (BALDRIDGE; CRANE, 1999).

Os adjuvantes aprovados atualmente para uso em humanos, a saber: os sais de alumínio, emulsões óleo em água e um antagonista de TLR "Toll-like receptor" (receptor do tipo Toll), não contemplam as necessidades de muitas formulações vacinais em desenvolvimento. A resposta a patógenos intracelulares, por exemplo, 
requer a indução de resposta imune celular, com presença de linfócitos T citotóxicos, praticamente ausentes quando sais de alumínio, conhecidos por induzirem fortes respostas de anticorpos, são empregados como adjuvantes, sendo que a natureza do antígeno utilizado e a via de administração na resposta imune adequada também são fatores a serem considerados (DE GREGORIO; TRITTO; RAPPUOLI, 2008). 


\subsection{Adjuvantes}

A molécula ou substância que amplifica ou intensifica a série de eventos imunológicos que compõem a resposta imune pode ser classificada como adjuvante. Desde 1925, diversos adjuvantes vêm sendo usados com o objetivo de aumentar a resposta imune contra antígenos específicos. Ramon em 1925 demonstrou a possibilidade de aumentar artificialmente a potência das antitoxinas tetânica e diftérica pela formulação das vacinas com substâncias como o ágar, sais metálicos, óleo, lecitina ou saponina. Durante os últimos oitenta anos, algumas formulações de adjuvantes têm sido desenvolvidas, sendo que poucas foram testadas em triagens clínicas e a maioria delas nunca foi aceita para a vacinação, devido à toxicidade e aos efeitos adversos (GUPTA; SIBER, 1995).

Várias substâncias estão sendo avaliadas quanto à sua possível atividade adjuvante, e muitos candidatos têm avançado nos ensaios clínicos, alguns demonstrando alta potência, associada com alta toxicidade, impedindo sua introdução na rotina clínica (O’HAGAN; MACKICHAN, 2001; PASHINE; VALIANTE; ULMER, 2005).

São exemplos clássicos de adjuvantes: emulsões, saponinas, sais de alumínio ou cálcio, polímeros surfactantes não iônicos, derivados de lipopolissacarídeos (LPS), micobactérias entre outros (OGRA; FADEN; WELLIVER, 2001).

Os únicos adjuvantes aprovados pelo FDA (Food and Drug Administration) são os sais de alumínio (hidróxido de alumínio e fosfato de alumínio), que têm ampla aplicação, tanto para uso humano quanto veterinário (PASHINE; VALIANTE; ULMER, 2005), e o MF59 aprovado pelo Comitê Europeu de Regulamentação Farmacêutica, mesmo assim, em alguns testes estes adjuvantes demonstraram induzir a produção de anticorpos $\operatorname{lgE}$, que estão associados às reações de hipersensibilidade (O'HAGAN; MACKICHAN, 2001).

\subsubsection{Classificação dos adjuvantes}

A heterogeneidade dos efeitos biológicos das muitas substâncias com propriedades adjuvantes torna muito complexa a seleção do adjuvante apropriado para uma finalidade específica e isto também se correlaciona com a grande 
diversidade da conformação molecular destas substâncias que determina qual das cinco vias de ativação: 1) imunomodulação, capacidade dos adjuvantes modificarem a rede de citocinas, resultando na regulação do sistema imune como um todo, 2) apresentação ou capacidade do adjuvante de preservar a integridade do antígeno e apresentá-lo às células imunes efetoras apropriadas, 3) indução de linfócitos $T$ citotóxicos $\mathrm{CD}^{+}$, para facilitar a incorporação ou persistência de peptídeos apropriados dentro do MHC-1,4) liberação ou entrega do antígeno que define a capacidade de um adjuvante de liberar o imunógeno para as células efetoras, geralmente as células apresentadoras de antígeno (APCs), 5) efeito depósito, que proporciona uma liberação prolongada do antígeno, podendo ser um depósito por curto tempo ou por longo prazo (COX; COULTER, 1997).

Os adjuvantes melhoram a resposta imune aos antígenos por diferentes maneiras: incremento da imunogenicidade de fracos imunógenos, aumento da velocidade e duração da resposta imune, modulação da especificidade, isotipo e distribuição das subclasses de anticorpos, estimulando resposta de linfócitos $T$ citotóxicos (CTL), promovendo a indução da imunidade de mucosa, aumentando a resposta imune de indivíduos imunologicamente imaturos ou senescentes, reduzindo o custo das vacinas pela diminuição das doses dos antígenos e ajudando a controlar a competição de antígenos em vacinas combinadas. Entretanto mesmo tendo estes conhecimentos, o mecanismo de ação de muitos adjuvantes permanece desconhecido, uma vez que a imunização desencadeia sucessão de respostas complexas, dificultando o entendimento do efeito primário dos adjuvantes (MOTA, 2006).

A seleção de um adjuvante deve ser baseada na via de administração e na resposta imune desejada (CLEMENTS; GRIFFITHS, 2002). A seleção do adjuvante não visa somente o aumento da resposta, mas sua modulação para o sistema Th1 ou Th2, ou seja, sua capacidade de induzir de maneira mais seletiva uma das subpopulações de células-T auxiliares (LIMA, 2008).

\subsubsection{Avanços, problemas e perspectivas}

A obtenção de novos adjuvantes é estimulada por um grande número de fatores, incluindo a fraca imunogenicidade dos antígenos puros e das vacinas de DNA, resposta imune geralmente baixa em certa faixa etária, como a fraca resposta 
de idosos para antígenos de $H$. influenza e um melhor conhecimento dos mecanismos da resposta imune e das novas rotas de liberação que têm sido exploradas, tais como a intradérmica, mucosa e intranasal (SESARDIC; DOBBELAER, 2004). Alguns parâmetros devem ser avaliados para a escolha de novos adjuvantes e combinação adjuvantes/vacinas, tais como a qualidade, 0 mecanismo de ação e a compatibilidade do adjuvante com o antígeno, incluindo composição quantitativa e qualitativa, características físicas e bioquímicas, pureza química e microbiológica.

No caso dos adjuvantes, há uma necessidade de demonstrar a compatibilidade com os antígenos (adsorção estável e eficaz) e toxicidade aceitável. Além desses aspectos, faz-se necessário um estudo comparativo com modelo animal apropriado, na presença e na ausência do adjuvante, avaliando o perfil de segurança da combinação antígeno-adjuvante e da via de administração escolhida (COMMITTEE FOR PROPRIETARY MEDICINAL PRODUCTS, 1997).

Alguns problemas podem ser citados durante o processo de obtenção de adjuvantes para vacinas, como capacidade limitada da função, modelos animais apropriados e problemas com os testes experimentais. Um dos maiores obstáculos para o desenvolvimento de novos adjuvantes é a toxicidade, que tem restringido a liberação e o uso de novos adjuvantes. Atualmente o balanço entre segurança e efeitos adversos é avaliado diferentemente para uma vacina profilática e para uma vacina terapêutica. No primeiro caso, apenas os adjuvantes que induzem efeitos adversos mínimos são aceitos, já para o uso terapêutico, são aceitos níveis de efeitos adversos mais elevados.

Diversas formulações vêm sendo testadas e apresentaram forte potencial adjuvante, tais como as emulsões, lipossomos, microesferas, saponinas, complexos imunoestimulantes, dentre outros. O primeiro registro da utilização de emulsões de óleo em procedimentos de imunização foi feito por Le Moignic e Pinoy (1916) que mostraram um aumento da resposta imune contra o antígeno, vacinando camundongos com Salmonella typhimurium inativada e emulsificada com óleo mineral. No entanto, foi com a introdução do adjuvante completo de Freund (CFA) (FREUND, 1956) que o uso das emulsões em procedimentos de imunização tornouse freqüente. O CFA é um dos mais potentes adjuvantes descritos sendo amplamente empregado para diversos antígenos e em procedimentos experimentais 
com animais de laboratório, porém, em sua formulação original, mostrou-se inaceitável para uso em humanos.

As vacinas veterinárias com adjuvantes à base de óleo são utilizadas com sucesso em programas de controle de doenças na América do Sul (PATIL et al., 2002) e outras partes do mundo. As emulsões lipídicas são adjuvantes efetivos capazes de induzir uma resposta imune elevada e duradoura (HILLEMAN, 1966; EDELMAN; TACKET, 1980; GUPTA; SIBER, 1995). Um dos maiores problemas encontrados para vacinas com adjuvantes oleosos é que o uso freqüente pode resultar em reações adversas indesejáveis, tais como formação de granulomas e cistos, que são atribuídas a diversos fatores incluindo impurezas do óleo (BARTELING; VREESWIJK, 1991; GUPTA et al., 1993) e no caso do CFA e IFA, muitos dos efeitos adversos são creditados ao óleo mineral, pelo fato de não ser biodegradável, formando lesões ulcerativas no local da injeção. Devido a esses efeitos colaterais, outros óleos e derivados vem sendo testados, como o esqualeno, esqualano e óleos vegetais, (MOTA, 2006).

Os adjuvantes de alumínio, que são os únicos aprovados para uso em humanos, foram introduzidos há mais de 70 anos por Glenny et al. (1926). Eles induzem uma forte resposta Th2, uma boa liberação do antígeno e apresentam um moderado efeito-depósito. A atividade biológica destes sais baseia-se em pelo menos três aspectos: formação de depósito de antígenos nos tecidos para produzir uma exposição prolongada; produção de antígenos particulados para facilitar a apresentação para APC; ativação do complemento e estimulação dos macrófagos para induzir retenção e ativação de linfócitos.

Adjuvantes licenciados (Tabela 1) foram desenvolvidos utilizando métodos empíricos, assim, eles não são ideais para muitos dos desafios da vacinação atual (PASHINE; VALIANTE; ULMER, 2005). 
Tabela 1 - Tipos de adjuvantes.

\begin{tabular}{|c|c|c|}
\hline Adjuvante $^{\mathrm{a}}$ & Exemplo & Descrição \\
\hline Sais minerais & Alumínio e sais de cálcio & $\begin{array}{l}\text { Licenciado para usa em humanos. Muitas antígenos } \\
\text { virais e bacterianos têm sido adsarvidas em } \\
\text { alumínio e sais de cálcio. }\end{array}$ \\
\hline Emulsães e farmulações surfactantes & $\begin{array}{l}\text { MF59, ASQ2, mantanide ISA-51 e } \\
\text { ISA-72D, QSZI| }\end{array}$ & Emulsões estáveis de detergente micrafluidizadas \\
\hline Veículas carreadores de partículas & $\begin{array}{l}\text { Micropartículas, complexas } \\
\text { imunoestimulatórios, lipossamos, } \\
\text { virassomas, partículas virais }\end{array}$ & $\begin{array}{l}\text { Partículas revestidas na superfície por antígenos } \\
\text { e/ou adjuvantes }\end{array}$ \\
\hline Derivados microbianos & $\begin{array}{l}\text { Manafasfaril Lipídio A, aliganucleotídeas, } \\
\text { toxina colérica, toxinas de E.coli, } \\
\text { lipoprateínas - LPS. }\end{array}$ & $\begin{array}{l}\text { Produtos bacterianos ou similares sintéticas são } \\
\text { potentes estimuladares do sistema imune inato. } \\
\text { Sinalização da maioria destes agentes par meio de } \\
\text { TLRs. }\end{array}$ \\
\hline Células e citacinas & Células dendríticas, IL-Z e GM-CSF & $\begin{array}{llll}\text { Células do sistema imune estimuladas por } \\
\text { citacinas. Células dendríticas autólogas } \\
\text { estimuladas por peptídeos derivados do tumos } \\
\text { apresentam de forma eficiente epítopos } \\
\text { antigênicas. }\end{array}$ \\
\hline
\end{tabular}

$\overline{~ a}$ As principais categorias de adjuvantes vacinais e veículos vacinais estão resumidos acima. A maioria destes está em estágios experimentais. Os únicos licenciados para uso humano são os sais de alumínio, a emulsão óleo em água MF59 e os virossomos.

FONTE: Pashine, Valiante e Ulmer (2005). 


\subsection{LPS}

O LPS é uma molécula anfifílica que está localizada na membrana externa de bactérias Gram-negativas, sendo liberado para o meio externo durante a fase logarítmica de crescimento in vivo e in vitro.

O LPS é composto de três distintos domínios estruturais: (1) o lipídio A, que é uma região basal glicolipídica que está ancorada à membrana externa, (2) uma região conhecida como core, (3) cadeia polissacarídica lateral, o antígeno $O$ (Figura 2). A estrutura do lipídio A é razoavelmente conservada entre os diferentes grupos bacterianos, indicando sua importância para o correto funcionamento da membrana externa.

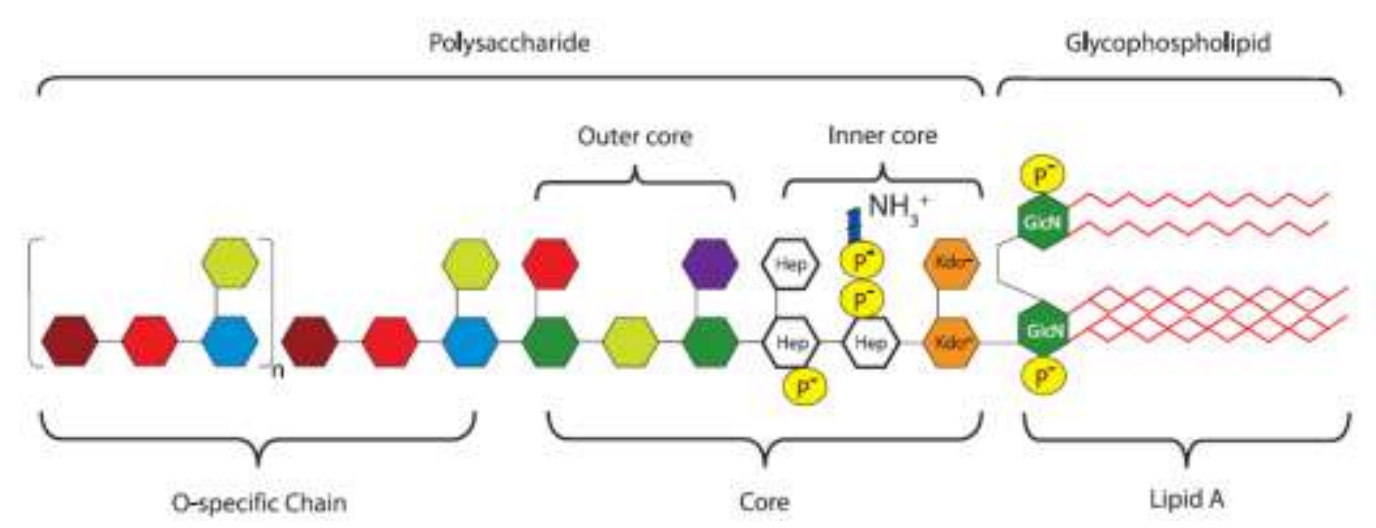

Figura 2: Representação esquemática da estrutura química do LPS bacteriano. GlcN - glucosamina; Kdo - ácido 2-keto-3-deoxioctonato; Hep - L-glicerol-D-manno-heptose; P - fosfato; EtN etanolamina; ${ }^{2}$ ácidos graxos.

FONTE: Caroff et al. (2002).

Em contraste ao LPS de B. bronchiseptica e B. parapertussis, a molécula de LPS de B. pertussis não contém o domínio do antígeno-O. Portanto, o LPS de $B$. pertussis é muitas vezes referido como lipooligossacáride. A B. pertussis produz duas formas dominantes de LPS, uma delas contendo 1,5 mais fosfato do que a outra (LE DUR; CHABY; SZABO, 1980).

Por muito tempo, acreditava-se que as espécies do mesmo gênero partilhavam estruturas lipídicas quase idênticas. No entanto, quando as composições de vários LPS de espécies de Bordetella foram comparados, a estrutura do lipídio A varia significativamente (Figura 3), enquanto a composição e o arranjo do core permanece inalterado. Curiosamente, a heterogeneidade encontrada 
no LPS que ocorre entre diferentes espécies de Bordetella, também pode ocorrer entre as diferentes cepas de uma mesma espécie (GEURTSEN, 2007).
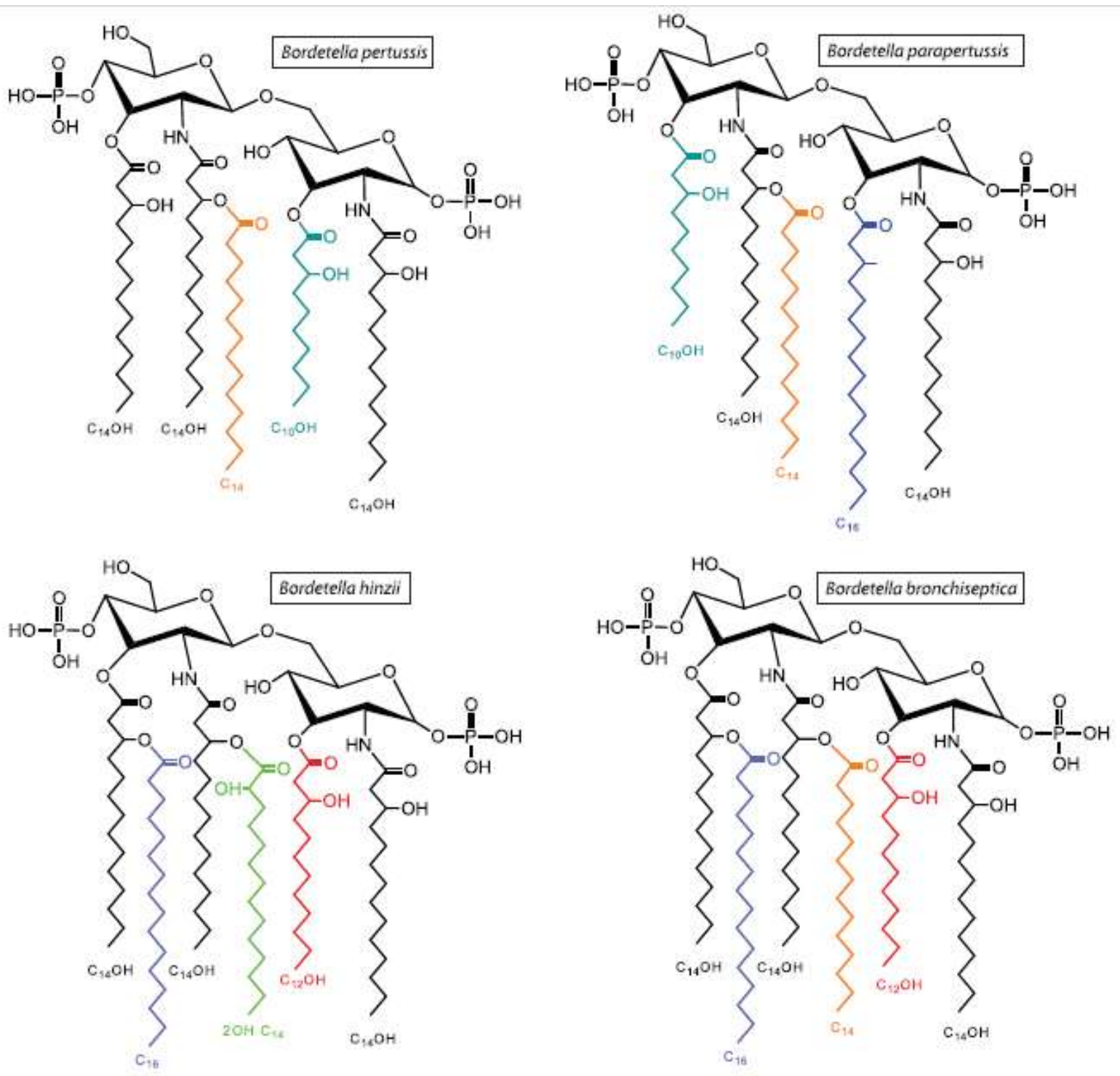

Figura 3: Estruturas do lipídio A de diferentes espécies de Bordetella, evidenciando as diferenças no número de cadeias de ácidos graxos.

FONTE: Caroff et al. (2002).

O LPS é uma potente molécula imunoestimulatória, apresentando tanto propriedade endotóxica como adjuvante, que juntamente com outras toxinas ativas, é o principal determinante para a reatogenicidade e efeito adjuvante da Vacina Pertussis. O LPS de Bordetella é pirogênico e tóxico e induz a produção e secreção de citocinas pró-inflamatórias IL-1 $\beta$, TNF- $\alpha$, IL-6, IL-12 e IL-18 e a citocina anti-inflamatória IL-10 in vivo, durante uma infecção natural com $B$. 
pertussis, e in vitro, por macrófagos após estimulação com LPS de B. pertussis. A função do LPS de $B$. pertussis como adjuvante é indicado pelo aumento da produção de anticorpos contra toxóides tetânicos e diftéricos, quando este LPS é co-administrado durante a vacinação (GEURTSEN, 2007).

A atividade endotóxica do LPS depende da composição do lipídio A (GALANOS et al., 1977; HOMMA et al., 1985). Estudos prévios indicaram que o grupo fosfato, bem como o número e o comprimento das cadeias acila são os determinantes críticos da atividade endotóxica (GEURTSEN et al., 2006). Esses estudos têm estimulado o desenvolvimento de derivados de LPS com propriedades potencialmente úteis. Alguns desses derivados apresentam reduzida atividade endotóxica, mantendo suas propriedades adjuvantes e imunostimulatórias (TAKAYAMA; RIBI; CANTRELL, 1981). Um dos exemplos mais conhecidos é o monofosforil lipídio A (MPL). O MPL foi desenvolvido como adjuvante para a aplicação em vacinas de uso humano, sendo que a diminuição da sua atividade endotóxica tem sido atribuída à reduzida capacidade de induzir a secreção de citocinas pró-inflamatórias como IL-6, IL-1 $\beta$ e TNF- $\alpha$ (OKEMOTO et al., 2006), e aumentar a secreção da citocina anti-inflamatória IL-10 pelos macrófagos (SALKOWSKI; DETORE; VOGEL, 1997). 


\subsection{Lipídio A}

A lise de bactérias Gram-negativas faz com que estas liberem o lipopolissacarídeo (LPS) da membrana externa de sua parede celular. A indução de anticorpos por LPS é bem conhecida, mas as reações adversas graves após a injeção em animais ou seres humanos fazem com que ele se torne impróprio para uso humano (RIETSCHEL et al., 1994).

O lipídio A é o componente mais endotóxico do LPS, e compreende uma série de espécies que têm a mesma estrutura global (dois resíduos acilados GlcNAc-P) mas que diferem no número de moléculas de ácidos graxos. A remoção por hidrólise das cadeias de polissacarídeos de LPS resulta no lipídio $A$, ou como o que ocorre naturalmente, a forma difosforil citotóxica ou a forma menos tóxica, o monofosforil (ERRIDGE; BENNETT-GUERRERO; POXTON, 2002).

A diversidade biológica do lipídio A destoxificado é exemplificada pela sua pluralidade funcional inclusive atuando cromo coadjuvante contra antígenos vacinais, seu peso aproximado (ou médio) molecular é 1,7-1,8 kDa, dependendo do número e identidade das cadeias de ácidos graxos presentes. A composição de ácidos graxos pode variar, dependendo do método de produção, que são vários, devido aos esforços para atenuar os atributos tóxicos do LPS, sem diminuir os benefícios imunoestimulatórios destes compostos.

Para avaliar as possíveis alterações na composição do LPS em mais detalhes, o lipídio A foi analisado por ESI-MS no modo negativo (Figura 4). Esta análise revelou a presença de quatro principais espécies de lipídio A no LPS de tipo selvagem. O pico de $1557 \mathrm{~m} / \mathrm{z}$ representa uma espécie penta-acilada bis-fosfato que é tipicamente encontrada em B. pertussis (CAROFF et al., 1994), enquanto que o pico $1477 \mathrm{~m} / \mathrm{z}$ corresponde a um penta-acilado mono-fosfato. Os dois picos restantes 1307 e $1251 \mathrm{~m} / \mathrm{z}$ representam espécies deaciladas do lipídio A. Além destas quatro espécies de lipídios $\mathrm{A}$ importantes, várias espécies menores foram detectadas. Os picos 1331 e $1387 \mathrm{~m} / \mathrm{z}$ correspondem às formas bis-fosforilada de íons moleculares 1251 e $1307 \mathrm{~m} / \mathrm{z}$, enquanto que o pico $1081 \mathrm{~m} / \mathrm{z}$ corresponde a uma forma de mono-fosfato com perda de resíduo (GEURTSEN et al., 2006). 
A

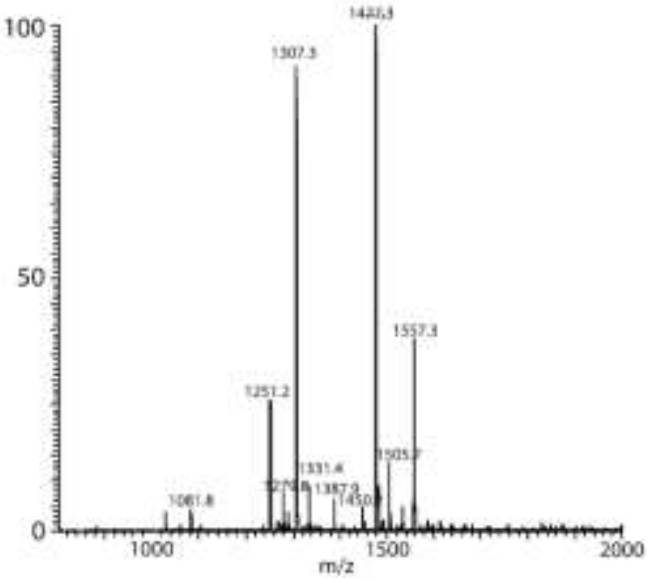

B

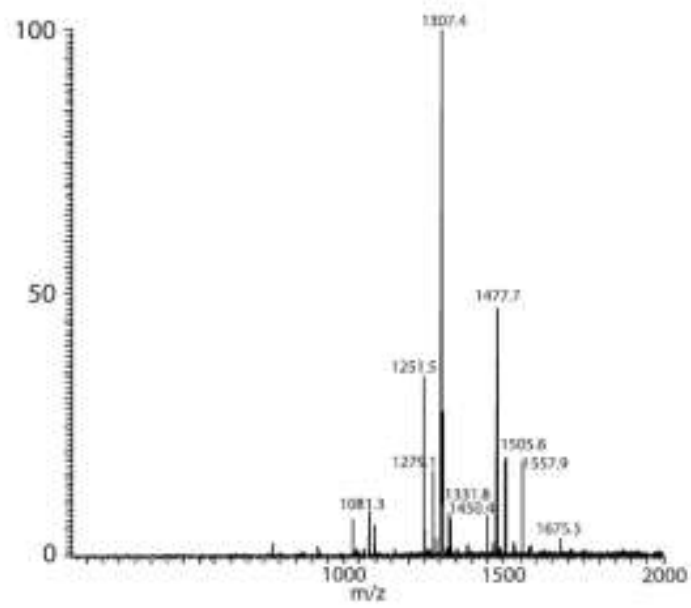

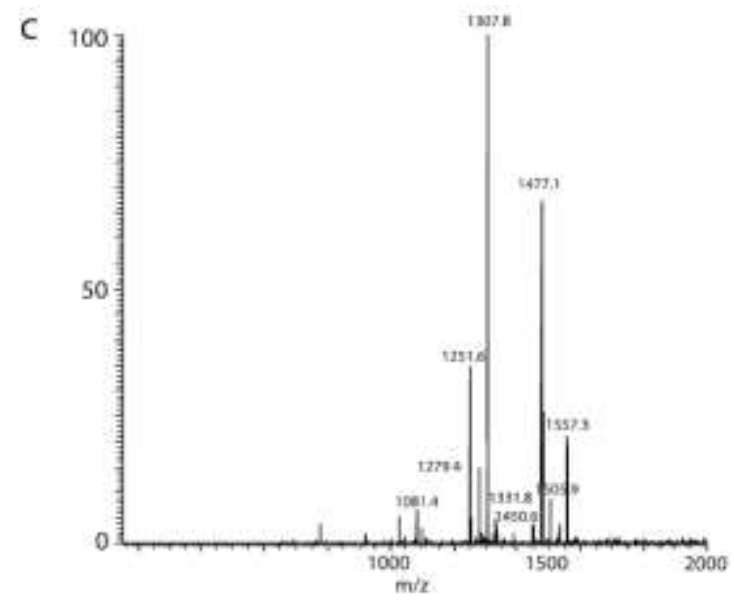

Figura 4: Análise estrutural do LPS purificado de B. pertussis por ESI-MS. (A) Picos principais: 1251, 1307.3, 1477.3, $1557.3 \mathrm{~m} / \mathrm{z}$. (B) $1251.5,1307.4,1477.7,1505.6 \mathrm{~m} / \mathrm{z}$. (C) 1251.6, 1307.8, $1477.1,1557.3 \mathrm{~m} / \mathrm{z}$. Sendo que estas variações representam o número de cadeias aciladas FONTE: Geurtsen (2007).

O MPL é uma forma detoxificada de lipídio $A$, obtido à partir do LPS isolado da parede celular de bactérias Gram-negativas (BALDRICK et al., 2002).

A atividade adjuvante do MPL é atribuída principalmente a sua capacidade de interagir com TLR4 nas APCs induzindo a cascata de citocinas pro-inflamatórias (SINGH; O'HAGAN, 2002). Vários estudos têm demonstrado a capacidade do MPL de ativar monócitos e macrófagos, sendo que através da ativação destas células, antígenos vacinais são mais facilmente fagocitados, processados e apresentados. É provável que o MPL seja capaz de continuar a influenciar o desenvolvimento da imunidade celular a antígenos vacinais por meio da ação dessas citocinas. Esta capacidade do MPL de estimular uma cascata de citocinas necessárias para a indução da imunidade celular torna-o um adjuvante efetivo. Mas o MPL também pode ser utilizado para reforçar e complementar a atividade de veículos vacinais, 
que funcionam como depósitos de antígeno adsorvidos em alumínio, lipossomos e emulsões contendo óleo (BALDRIDGE; CRANE, 1999).

O MPL mostrou boa "tolerabilidade" e atividade adjuvante em voluntários imunizados com formulações em combinação com hidróxido de alumínio ou em emulsões óleo em água (SINGH; O’HAGAN, 2002).

Devido à sua natureza anfifílica o MPL pode complementar e reforçar a atividade adjuvante das emulsões óleo em água, agindo como uma opsonina e ser entregue juntamente com o antígeno (BALDRIDGE; CRANE, 1999).

Estudos têm também demonstrado a eficácia do MPL quando formulado em emulsões óleo em água que são menos reatogênicas (MOMIN; GARCON, 2004), que as emulsões água em óleo do tipo Freund (MURRAY; COHEN; HARDEGREE, 1972). As partículas de óleo revestidas com o MPL são reconhecidas por macrófagos e células dendríticas, aumentando a apresentação de antígeno do complexo principal de histocompatibilidade classe I (MHC), resultando numa ativação dos linfócitos T citotóxicos (O’HAGAN; SINGH; GUPTA, 1998; KPVACSOVICS-BANKOWSKI et al., 1993).

Formulações com adjuvantes constituem vacinas potentes do ponto de vista imunológico, porém, com vários obstáculos a serem superados considerando, a segurança, a eficácia e a qualidade do processo produtivo.

É provável que derivados de LPS, sejam os primeiros adjuvantes vacinais a serem aprovados para uso generalizado desde o hidróxido de alumínio, porque gera clinicamente uma resposta imune, e tem aproximadamente $0,1 \%$ da toxicidade inflamatória da molécula de LPS (MATA-HARO et al., 2007). Em 2001 Baldrick, et. al, apresentou uma variedade de estudos pré-clínicos, que foram realizados com o MPL, para analisar o potencial toxicológico deste produto. A ausência de resultados tóxicos em modelos animais dá apoio à hipótese de que estes componentes sejam seguros para uso humano.

\subsubsection{Lipídio A de Bordetella pertussis}

O gênero Bordetella apresenta nove espécies. O lipídio A de pelo menos sete delas tem sua estrutura conhecida tendo sido ressaltada à notável variabilidade desta estrutura entre as espécies e mesmo entre as linhagens. Esta variabilidade estrutural tem sido atribuída à baixa especificidade enzimática. Isto torna a 
Bordetella um gênero muito interessante para estes estudos de definição estrutural. Vários processos extrativos que diferem nas condições de hidrólise (brandas ou drásticas) utilizadas para a clivagem da ligação do lipídio A com o polissacarídeo, são descritos para o isolamento do lipídio $A$ de Bordetella pertussis. Condições drásticas principalmente de $\mathrm{pH}$ e temperatura podem ocasionar perda do fosfato e/ou das cadeias aciladas do lipídio $A$ resultando em modificações das atividades biológicas da molécula (CAROFF et al., 1986; CAROFF; TACKEN; SZABÓ, 1988; TIRSOAGA et al., 2007). Como sua atividade biológica depende desta estrutura peculiar, a injeção do lipídio A purificado pelos diferentes processos extrativos num modelo animal pode ou não desencadear a mesma resposta tóxica do LPS íntegro. A hidrólise do LPS de Bordetella pertussis com ácido acético $(\mathrm{pH} \mathrm{3,4}$ por 1 hora a $100{ }^{\circ} \mathrm{C}$ ) mesmo na ausência de detergentes, rende preparações de isolados de Lipídio A que perdem $80 \%$ de seu fosfato ácido-lábil (CAROFF; TACKEN; SZABÓ, 1988).

Vacinas DTP podem ser tóxicas, devido ao componente pertussis presente em sua formulação. O Instituto Butantan produz e administra sua vacina DTP com sucesso há quase 20 anos. O Japão desenvolveu uma Vacina Pertussis Acelular VPa (somente com componentes bacterianos) adotada por países desenvolvidos, mas incompatível para o orçamento dos países subdesenvolvidos ou em desenvolvimento. O Instituto Butantan seguiu outra linha: remover o LPS bacteriano, responsável pela toxicidade, como inovação no processo produtivo da vacina tradicional (RAW, 2007, HIGASHI et al., 2009). Essa nova Vacina Pertussis Low $\left(\mathrm{VP}_{\mathrm{L}}\right.$ ), que compõe a nova Vacina Tríplice Bacteriana (DTP $\mathrm{L}$ ), que tem a segurança da Vacina Acelular, foi testada num ensaio clínico induzindo resposta imune humoral e celular similar à vacina tradicional ou à Vacina Tríplice Acelular (DTPa) e sem aumento de custo.

Neste novo processo de produção, dois outros subprodutos foram obtidos, uma vacina pertussis acelular e o adjuvante BPMPLA, capaz de induzir a produção de interferon- $\beta$ e aumentar a ativação das células $T$ sem indução de resposta inflamatória. BpMPLA pode aumentar a capacidade de produção e diminuir o custo das vacinas contra influenza A, sazonal ou pandêmica (H5N1) (QUINTILIO et al., 2009, MIYAKI et al., 2010). O fato deste adjuvante ser praticamente composto por espécies tetraciladas $(\mathrm{m} / \mathrm{z}$ de 1291$)$ suscitou questionamentos sobre seu real potencial adjuvante incitando o grupo a continuar pesquisando a obtenção de outros 
derivados tóxicos de LPS de Bordetella pertussis (BpLipídioA) e implementando os testes de caracterização destes.

O BpLipídioA foi obtido como subproduto da destoxificação da Vacina Pertussis (celular) por extração orgânica e submetido à hidrólise ácida, seguido por neutralização do $\mathrm{pH}$, resfriamento, envase e liofilização.

A qualidade de BpLipídioA como de qualquer outro produto farmacêutico ou de um imunobiológico é estabelecida através de testes mínimos necessários, que visam a caracterização e especificação de sua estrutura, identidade, pureza, concentração, potência e inocuidade, que resumindo representam sua segurança e eficácia. 


\subsection{Vacina recombinante contra Hepatite B}

A Hepatite $B(\mathrm{HB})$ é uma doença imunoprevenível e de notificação compulsória que se constitui um importante problema de saúde pública mundial. Estima-se que $45 \%$ da população mundial viva em áreas onde a infecção crônica pelo vírus da $\mathrm{HB}$ é altamente endêmica ( $>7 \%$ da população é $\mathrm{HBsAg}+$ ), $43 \%$ em regiões de endemicidade intermediária (2 a $7 \%$ ) e $12 \%$ em locais de baixa endemicidade (<2\%) (WHO, 2001; SHEPARD et al., 2006).

Entre as medidas para o controle da HB e de suas complicações, a vacinação tem se mostrado de grande impacto. No Brasil, 13 anos após a introdução da vacinação, regiões endêmicas apresentam uma redução de até cinco vezes o número de indivíduos portadores de HBsAg na comunidade (BRAGA et al., 2004).

$O$ Instituto Butantan é produtor da vacina recombinante contra hepatite $B$, que foi desenvolvida a partir da tecnologia do DNA recombinante. A vacina é constituída pelo antígeno de superfície do vírus da hepatite $B(\mathrm{HBsAg})$ altamente purificado (produzido através da inserção de um plasmídeo contendo o gene do antígeno em células de levedura) e adsorvido em hidróxido de alumínio (COSTA et al., 1997; MARTINS et al., 2004).

Um estudo preliminar da potencial atividade adjuvante de BpLipídioA em modelo animal foi realizado através de formulações com o antígeno recombinante de superfície do vírus da hepatite B produzido no Instituto.

Os outros produtores da vacina recombinante contra hepatite $\mathrm{B}$, a fim de melhorar as taxas de soroconversão $(91-100 \%)$ das populações de não respondedores (pacientes que fazem hemodiálise ou idosos), desenvolveram um novo sistema adjuvante contendo sal de alumínio e o lipídio A monofosforilado (SBAS4) que melhorou a resposta imune humoral in vivo e celular in vitro, sendo o sistema considerado eficaz, seguro e com boa tolerabilidade (THOELEN et al., 1998; THOELEN; DE CLERCQ; TORNIEPORTH, 2001). 


\section{CAPÍTULO II}

\section{OBJETIVOS}

\subsection{Objetivo Geral}

Desenvolver a metodologia de produção e caracterização de um possível adjuvante para antígenos vacinais, obtido como subproduto da vacina pertussis celular de baixa toxicidade pela remoção do LPS, utilizando-o como matéria prima para fabricação do novo adjuvante agregando ainda mais valor à planta e às tecnologias de produção.

\subsection{Objetivos Específicos}

- Avaliar a metodologia para produção do lipídio A, derivado do LPS de Bordetella pertussis.

- Estabelecer, desenvolver e padronizar os testes necessários para reconhecimento das características do produto.

- Analisar os resultados de todos os testes e verificar a reprodutibilidade das amostras analisadas.

- Verificar uma possível atividade adjuvante do lipídio A administrado com a vacina de hepatite $B$, aumentando sua eficácia.

- Verificar se há aumento de resposta da vacina contra hepatite $B$, administrada com o adjuvante formulado em suspensão, com e sem o hidróxido de alumínio. 


\subsection{Justificativa}

Uma das missões do Instituto/Fundação Butantan é fornecer vacinas de excelente qualidade (eficazes e seguras) e com custo compatível com os orçamentos destinados a esta finalidade pelo poder público. Neste sentido o Butantan não tem medido esforços para tornar realidade esta missão, investindo em novas tecnologias recebidas por transferência de "know how" ou principalmente desenvolvidas in situ além dos investimentos na capacitação profissional de técnicos. A meta do Butantan tem sido atender todas as exigências das boas práticas de manufatura ainda que estejam cada vez mais complexas e sofisticadas. Assim a pesquisa de novas vacinas, medicamentos e insumos como o adjuvante BpLipídioA desenvolvido e caracterizado nesta dissertação é apenas mais um exemplo promissor destes esforços. 


\section{CAPÍTULO III}

\section{MATERIAIS E MÉTODOS}

\subsection{Materiais}

3.1.1 Animais: As espécies de animais utilizadas foram: coelho albino, linhagem Nova Zelândia Branco (NZB), peso de 1,5 a $2,5 \mathrm{Kg}$ e camundongos albinos (Mus musculus) de $14 \mathrm{~g}$ a $16 \mathrm{~g}$ ou de $17 \mathrm{~g}$ a $22 \mathrm{~g}$, todos machos, da linhagem Swiss webster.

3.1.2 Reagentes e kits: Todos os reagentes utilizados foram de grau analítico (P.A.). Ácido sulfúrico $\left(\mathrm{H}_{2} \mathrm{SO}_{4}\right)$, ácido periódico $\mathrm{HIO}_{4}$, reagente de arsenito de sódio $\mathrm{NaAsO}_{2}$, ácido clorídrico $\mathrm{HCl}$, ácido tiobarbitúrico (TBA), dimetil sulfóxido (DMSO) $\mathrm{C}_{2} \mathrm{H}_{6} \mathrm{O}_{5}$, soro albumina bovina, solução fisiológica tamponada $\mathrm{pH} 6,8$, clorofórmio $\left(\mathrm{CHCl}_{3}\right)$, metanol $\left(\mathrm{CH}_{3} \mathrm{OH}\right.$ ), trietilamina $\mathrm{N}\left(\mathrm{CH}_{2} \mathrm{CH}_{3}\right)_{3}$, reativo de Purpald ${ }^{\circledR}$ (Sigma Aldrich, Steinheim, Alemanha), metaperiodato de sódio $\left(\mathrm{NalO}_{4}\right)$, iodomercurato de potássio alcalino, molibdato de amônio $\left.\left(\mathrm{NH}_{4}\right)_{6} \mathrm{Mo}_{7} \mathrm{O}_{24} \cdot 4 \mathrm{H}_{2} \mathrm{O}\right)$, ácido ascórbido $\left(\mathrm{C}_{6} \mathrm{H}_{8} \mathrm{O}_{6}\right)$, ácido perclórico $\left(\mathrm{HClO}_{4}\right)$, álcool $\mathrm{N}$-butílico $\left(\mathrm{C}_{4} \mathrm{H}_{10} \mathrm{O}\right)$, fosfato de potássio monobásico $\mathrm{KH}_{2} \mathrm{PO}_{4}$, kit BCA (Calbiochem Novabiochem Novagen) e kit Murex antiHBs (Abbott).

3.1.3 Equipamentos, acessórios e materiais de consumo: Espectrofotômetro Ultrospec 2100 (Amersham Biosciences), fotômetro para microplacas Multiskan EX (Labsystems), microplacas NUNC (Apogent), placas de vidro com silica gel para cromatografia de camada delgada (TLC) de tamanho $10 \times 20 \mathrm{~cm}$, com indicador fluorescente (Aldrich), cuba de vidro para corrida (TLC), sistema de imagem de vídeo computadorizado Stratagene Eagle Eye II Video Imaging System, espectro de massa Esquire 3000 plus (Bruker Daltonics), sistema de caracterização de partículas Malvern Zetasizer Nano, microfluidizador Microfluidizer ${ }^{\circledR}$ M110EH-30. 
3.1.4 Produtos: Lipídio A de Bordetella pertussis (BpLipídioA) Lotes 1, 2, 3, 4, 5, 6 e 7; Filtrado LPS Lotes 1, 2, 3, 4, 5, 6 e 7, Vacina Pertussis (Figura 5). Proteína recombinate de hepatite $B$.

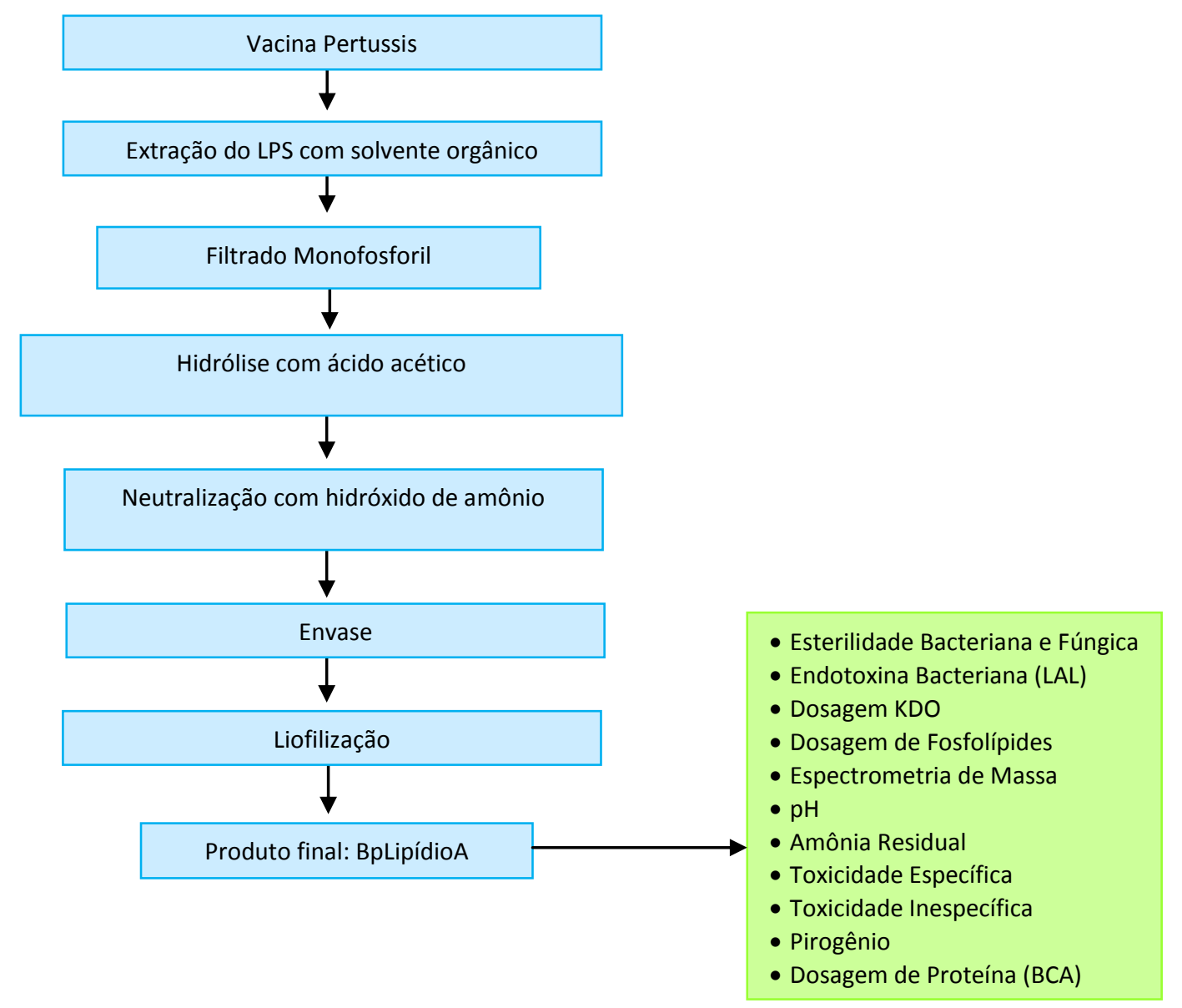

Figura 5: $\square$ Fluxograma de produção do lipídio A de Bordetella pertussis, o Lipídio A de Bordetella pertussis é obtido à partir da destoxificação da vacina pertussis celular por extração orgânica do LPS, que é submetido à hidrólise ácida, seguido por neutralização com hidróxido de amônio. O produto então é resfriado, envasado e liofilizado.

Testes realizados para caracterização do produto e avaliação da qualidade e reprodutibilidade dos diferentes Lotes. 


\subsection{Métodos Analíticos}

Para introdução dos testes de controle de qualidade para o BpLipídioA, tomou-se como base a tabela de resultados analíticos do Lipídio A destoxificado da empresa Avanti Polar Lipids, cujo produto é derivado de Salmonella minnesota R595 (Tabela 2).

Tabela 2 - Lipídio A destoxificado de Salmonella minnesota. Resultados analíticos típicos.

\begin{tabular}{|c|c|c|}
\hline Test & Limits & Results \\
\hline TLL & $\begin{array}{l}\text { "Conforms to standard of 7, } 6 \text { and } 5 \text { acyl } \\
\text { Lipid A fractions" }\end{array}$ & Pass \\
\hline KDD & $<1.0 \%$ & None detected 国 0.1\% \\
\hline HPLC & Ratio=acyl component/ $€$ & 7:6:5 асу1 гаtio=12.5:24:63.5 \\
\hline $\begin{array}{l}\text { Electrospray Mass } \\
\text { Spectrometry } \\
\text { (Negative } \\
\text { ionization) }\end{array}$ & $\begin{aligned} 7 \text { acyl }[M-H]^{-} & =1955 \pm \text { lamu } \\
6 \text { acyl }[M-H]^{-} & =1717 \pm \text { lamu } \\
5 \text { acyl }[M-H]^{-} & =1507 \pm \text { lamu }\end{aligned}$ & $\begin{aligned} 7 \text { acyl }[M-H]^{-} & =1955.2 \pm \text { lamu } \\
6 \text { acyl }[M-H]^{-} & =1717.6 \pm \text { lamu } \\
5 \text { acyl }[M-H]^{-} & =1506.6 \pm \text { lamu }\end{aligned}$ \\
\hline Phosphorus & 400-800 nmoles P/mg & 573 nmoles P/mg \\
\hline Protein & $<0.5 \%$ & None detected 国 0.15\% \\
\hline Nucleic Acid & $<1.0 \%$ & None detected 回 0.24\% \\
\hline Glucasamine & 8००-1600 nmoles/mg & 1128 nmoles/mg \\
\hline Calcium & To be determined & 210 ppm \\
\hline Ammoniun & To be determined & $60 \mathrm{Pm}$ \\
\hline
\end{tabular}

Test: testes

Limits: limites

Results: resultados

FONTE: Avanti Polar Lipids (2009). 


\subsubsection{Dosagem de KDO}

A dosagem de KDO foi realizada para determinação da quantidade de LPS na matéria prima (Filtrado de LPS) a ser utilizada na produção do adjuvante BpLipídioA, sendo que no produto final foi também empregada, com a finalidade de verificar ainda a presença deste açúcar que liga a região do core do LPS à glucosamina do lipídio A.

A determinação do KDO foi realizada por duas metodologias distintas, a primeira utilizando ácido tiobarbitúrico, modificada por Osborn em 1963 e a segunda utilizando o reativo de Purpald ${ }^{\circledR}$ (LEE; TSAI, 1999), que quantifica o formaldeído resultante da oxidação do KDO e das heptoses pelo periodato.

\subsubsection{Método do ácido tiobarbitúrico}

Para a realização deste teste foi utilizado $1 \mathrm{~mL}$ de cada uma das amostras dos Lotes, sendo estas distribuídas em tubos para serem submetidas a hidrólise com ácido sulfúrico $0,02 \mathrm{~N}$ a $100 \stackrel{\circ}{\circ}$ por 20 minutos. Após esta etapa foi adicionado $125 \mu \mathrm{L}$ de ácido periódico nas amostras já hidrolisadas e mantido por 20 minutos a temperatura ambiente, até a adição de $250 \mu \mathrm{L}$ de reagente de arsenito de sódio diluído em ácido clorídrico seguido de agitação. Após 2 minutos foi adicionado $1 \mathrm{~mL}$ de ácido tiobarbitúrico para uma nova hidrólise a $100^{\circ} \mathrm{C}$ por 12 minutos. Enquanto as amostras ainda mantinham alta temperatura ( $\pm 80 \stackrel{\circ}{\circ}$ ) foi adicionado 1 $\mathrm{mL}$ de dimetilsulfóxido, nova agitação e realização das leituras em espectrofotômetro com OD de 548 nm (Figura 6).

\subsubsection{Método do reativo de Purpald ${ }^{\circledR}$}

Nesta técnica a quantidade de amostra requerida para o teste foi de 50 $\mu \mathrm{L}$ distribuídos em uma microplaca, seguida da adição de $50 \mu \mathrm{L}$ de metaperiodato de sódio $32 \mathrm{mM}$. As amostras foram mantidas por 25 minutos a temperatura ambiente protegidas da luz. Após este período $50 \mu \mathrm{L}$ de reativo de Purpald ${ }^{\circledR} 136 \mathrm{mM}$ foi adicionado e as amostras foram mantidas por 20 minutos sob as mesmas condições. Por último foi adicionado $50 \mu \mathrm{L}$ de metaperiodato de sódio $64 \mathrm{mM}$ e manutenção por 20 minutos ao abrigo da luz até a adição do álcool N-butílico 
necessário para a redução da tensão superficial antes da realização da leitura numa absorbância de 550 nm no leitor Multiskan EX. (Figura 6).

A

B

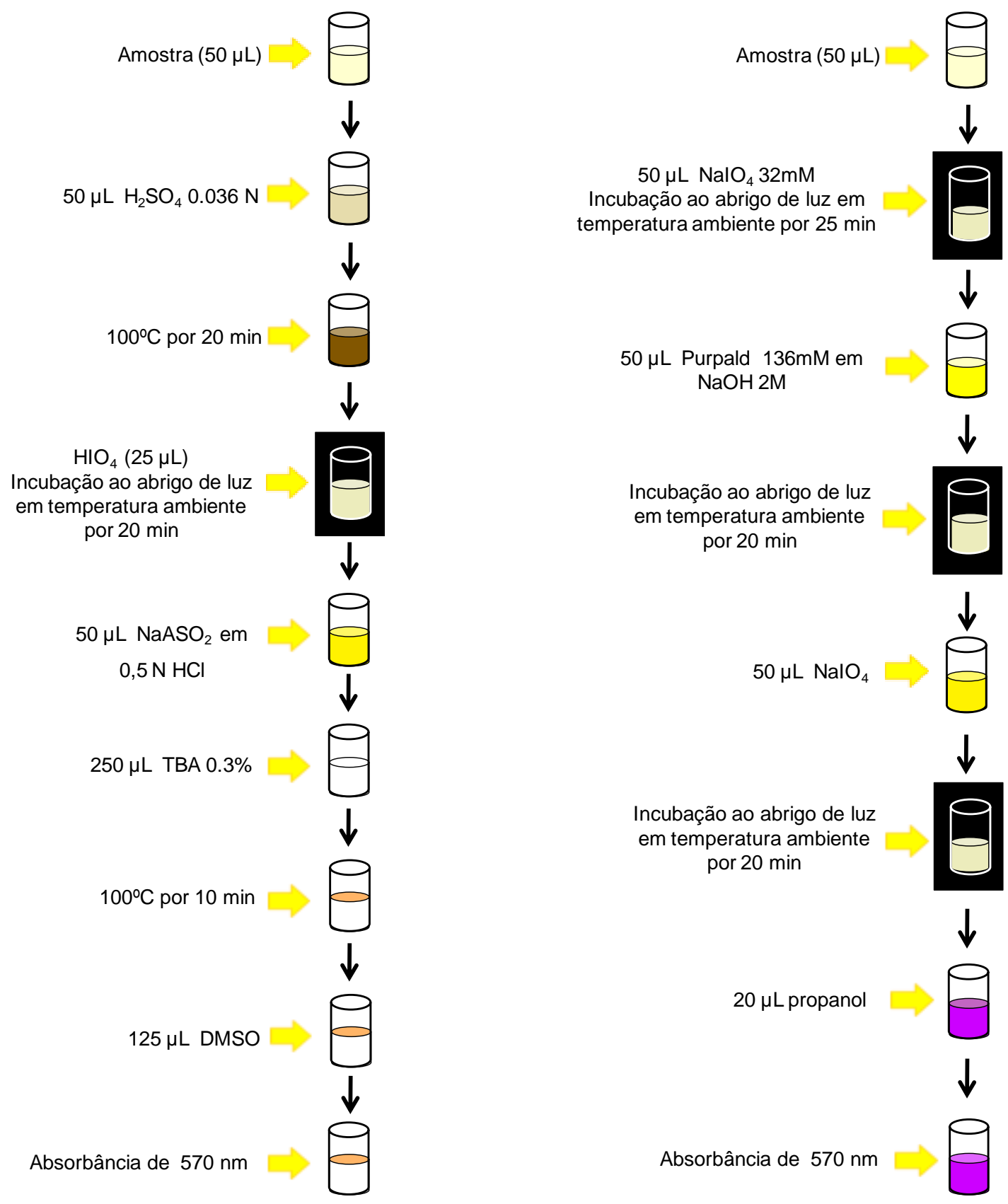

Figura 6: Representação esquemática das metodologias aplicadas para a dosagem de KDO. (A) Método com ácido tiobarbitúrico e (B) Método com reativo de Purpald ${ }^{\circledR}$. 


\subsubsection{Dosagem de Proteína}

A dosagem de proteína foi realizada pelo método do ácido bicinconínico utilizando o Kit de BCA da Calbiochem Novabiochem Novagen. A solução padrão foi preparada com soro albumina bovina (BSA) na concentração de $2 \mathrm{mg} / \mathrm{mL}$.

A curva padrão com seus respectivos pontos e concentrações está descrita na tabela abaixo. O volume de amostra de cada um dos lotes foi de $25 \mu \mathrm{L}$, distribuídos em uma microplaca onde foi adicionado o reagente de BCA (preparado previamente) permanecendo em agitação por 30 segundos até ser levada à incubação a $37 \stackrel{\circ}{\circ}$ por 30 minutos, sendo retirada e mantida a temperatura ambiente. A leitura foi realizada no leitor Multiskan EX numa absorbância de 562 nm

Tabela 3 - Curva padrão para dosagem de proteína com concentrações variando entre $10 \mu \mathrm{g}$ a $640 \mu \mathrm{g}$ de BSA.

\begin{tabular}{c|c|c|c}
\hline Ponta curva & $\begin{array}{c}\text { Coneentraghä́ } \\
(\mu g)\end{array}$ & $\begin{array}{c}\text { Volume do } \\
\text { padrä0 (BSA) }\end{array}$ & $\begin{array}{c}\text { Volume do } \\
\text { diluente }\end{array}$ \\
\hline 1 & 10 & $5 \mu \mathrm{L}$ & $995 \mu \mathrm{L}$ \\
\hline 2 & 20 & $10 \mu \mathrm{L}$ & $990 \mu \mathrm{L}$ \\
\hline 3 & 40 & $20 \mu \mathrm{L}$ & $980 \mu \mathrm{L}$ \\
\hline 4 & 80 & $40 \mu \mathrm{L}$ & $960 \mu \mathrm{L}$ \\
\hline 5 & 160 & $80 \mu \mathrm{L}$ & $920 \mu \mathrm{L}$ \\
\hline 6 & 320 & $160 \mu \mathrm{L}$ & $840 \mu \mathrm{L}$ \\
\hline 7 & 640 & $320 \mu \mathrm{L}$ & $680 \mathrm{~L}$ \\
\hline
\end{tabular}




\subsubsection{Cromatografia de camada delgada (TLC)}

Esta técnica de separação foi empregada para verificação do perfil dos componentes das amostras, representados como bandas de espécies moleculares com diferentes velocidades de migração no material estacionário (sílica).

Cada uma das amostras liofilizadas foi ressuspendida com $100 \mu \mathrm{L}$ de clorofórmio:metanol 3:1, e pingada em sua totalidade na placa de sílica, nos pontos de aplicação demarcados previamente (Figura 7).

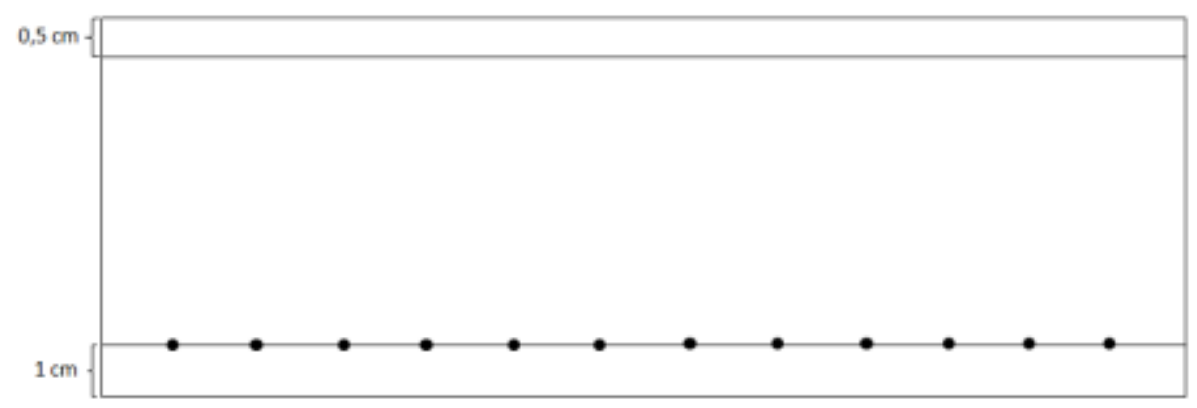

Figura 7: Esquema da placa de sílica para o teste com os pontos de aplicação das amostras.

Após a aplicação a placa permaneceu a temperatura ambiente para a secagem das amostras, após secagem, foi introduzida na câmara previamente saturada (Figura 8) com solução de clorofórmio, metanol, trietilamina e $\mathrm{H}_{2} \mathrm{O}$ na proporção de 3:1,5:0,25:0,1 (EL HAMIDI et al., 2005) e retirada após 25 minutos de corrida. A placa deixada para secagem em temperatura ambiente antes da ativação por luz UV no transiluminador.
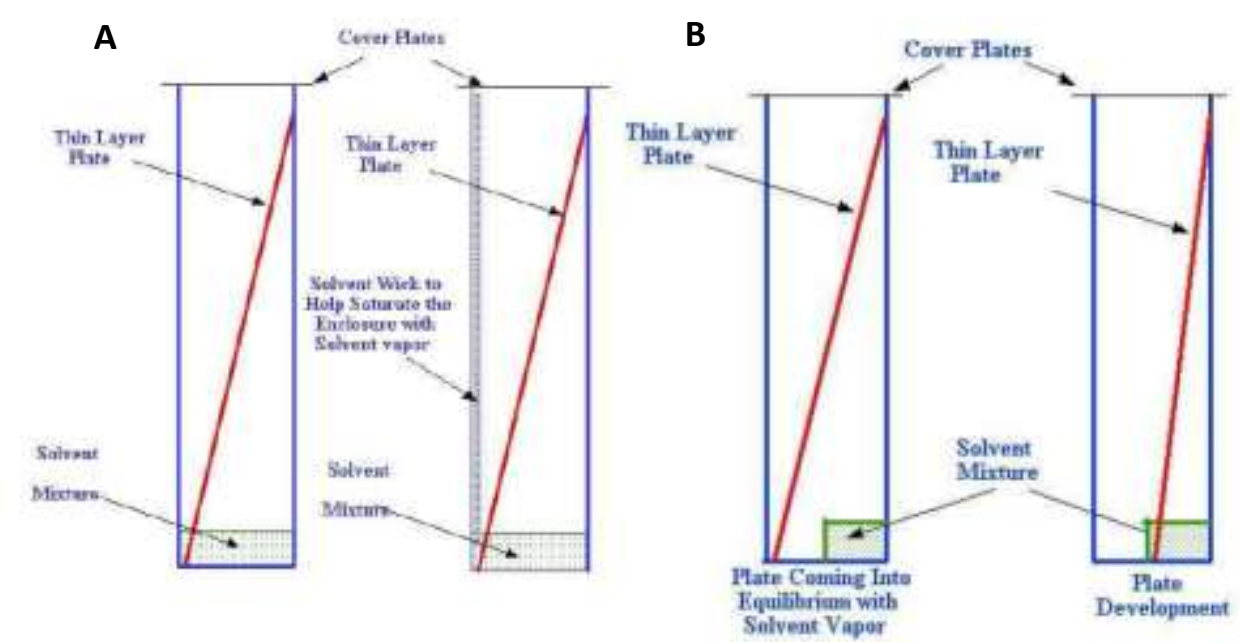

Figura 8: Câmara de corrida e placas de sílica. (A) saturação da câmara e (B) inserção da placa para corrida.

FONTE: Marques (2009). 


\subsubsection{Determinação de $\mathrm{pH}$}

As amostras previamente liofilizadas foram ressuspendidas com $20 \mathrm{~mL}$ de água para injetáveis e inseridas no medidor de $\mathrm{pH}$ para leitura, previamente calibrado com os tampões 4,0 e 7,0.

\subsubsection{Teor de amônia residual}

Devido a utilização do hidróxido de amônia como agente neutralizador durante o processo de produção, a dosagem do teor de amônia residual foi realizada para verificar a quantidade de acetato de amônio residual no produto final.

As amostras foram ressuspendidas com água purificada para uma concentração inicial de $10 \mathrm{mg} / \mathrm{mL}$, seguindo-se as diluições conforme descrito na tabela 4. Após a diluição, foi adicionado $100 \mu \mathrm{L}$ do regente padrão (iodomercurato de potássio alcalino) em todos os tubos e observado se houve alteração da coloração das amostras para amarelo ou laranja, determinante do resultado positivo.

Tabela 4 - Esquema das diluições para determinação de um limite de detecção de acetato de amônio. $\square$ O tubo 3 representa a concentração de BpLipídioA a ser utilizada na formulação vacinal. Este tubo deve sempre apresentar um resultado negativo para detecção de amônia.

\begin{tabular}{c|c|c|}
\hline Tubo & Diluiģä̃ & Concentraģäo \\
\hline 1 & $1: 10$ & $1 \mathrm{mg} / \mathrm{mL}$ \\
\hline 2 & $1: 100$ & $0.1 \mathrm{mg} / \mathrm{mL}$ \\
\hline 3 & $1: 1000$ & $0,01 \mathrm{mg} / \mathrm{mL}$ \\
\hline 4 & $1: 10.000$ & $1 \mathrm{\mu g} / \mathrm{mL}$ \\
\hline 5 & $1: 100.000$ & $0.1 \mathrm{\mu g} / \mathrm{mL}$ \\
\hline 6 & $1: 1.000 .000$ & $0,01 \mathrm{\mu g} / \mathrm{mL}$ \\
\hline
\end{tabular}




\subsubsection{Dosagem de Fósforo}

BpLipídioA foi quantificado pela dosagem do fósforo ancorado à glucosamina, pela metodologia descrita por Rouser em 1970.

Tubos contendo volumes de 10 e $50 \mu \mathrm{L}$ das amostras em triplicata foram secos em bloco digestor a $120^{\circ} \mathrm{C}$, juntamente com os tubos contendo solução padrão de fosfato ( $1 \mathrm{mM}$ de $\mathrm{KH}_{2} \mathrm{PO}_{4} \mathrm{PM}$ 136,09) nas concentrações de 50 e 100 nmoles. Em seguida foi adicionado $400 \mu \mathrm{L}$ de ácido perclórico concentrado e retornado ao bloco digestor por mais 1 hora a $180 \stackrel{\circ}{\circ} \mathrm{C}$ (sendo esta a condição essencial para a mineralização do fosfato). As amostras retiradas do bloco foram resfriadas a temperatura ambiente, e adicionado água, molibdato de amônio, ácido ascórbido com subsequente agitação após cada adição. A seguir os tubos foram colocados em banho-maria fervente por 10 minutos e resfriados para a realização da leitura em espectrofotômetro no comprimento de onda de $797 \mathrm{~nm}$.

A densidade óptica para leitura nos permite um padrão de 50 nmoles com uma DO de 0,6 e um padrão de 100 nmoles com uma DO de 1,2. 


\subsubsection{Espectrometria de massa (ESI-MS)}

Neste trabalho a espectrometria de massas foi utilizada para identificar o LPS extraído de Bordetella pertussis e caracterizar o produto final obtido, contribuindo com informações sobre sua estrutura.

A essência da técnica envolve a geração de íons posteriormente detectados por campos eletromagnéticos externos. A resolução advem dos métodos que são usados para a geração desses mesmos íons e no modo de realização de sua análise.

As análises foram realizadas na Central Analítica do Instituto de Química da USP (CA/IQ/USP) utilizando o equipamento Esquire 3000 plus (Bruker Daltonics) que dispõe dos métodos de ionização por electrospray (ESI) e ionização química em pressão atmosférica (APCl) sendo estes métodos intercambiáveis. A energia de ionização destes métodos é poderosa e produz múltiplos íons precursores, que são acumulados, aprisionados, selecionados e então fragmentados gerando produtos iônicos. Uma importante característica é que as amostras a analisar devem ser introduzidas em solução, o que faz com que seja possível o acoplamento com muitas técnicas de separação.

O equipamento pode ou não estar conectado a um cromatógrafo líquido de alto desempenho (HPLC). A introdução da amostra pode ser tanto por infusão contínua ou por infusão direta simples. O instrumento pode detectar massas de 50 a 6.000 Da com análises em modo positivo e negativo.

O espectro de massa formado é do tipo gráfico de barra vertical, no qual cada barra representa um íon tendo uma razão massa/carga específica $(\mathrm{m} / \mathrm{z})$ e 0 comprimento das barras indicam a abundância relativa do íon. $O$ íon de maior intensidade é assinalado com abundância 100 e seria o pico base. Os íons formados no espectrômetro de massa tem uma carga única específica que equivaleria à própria massa. É possível resolver íons diferindo entre si por apenas uma unidade atômica (amu). O íon de maior massa no espectro é normalmente considerado a espécie iônica molecular e os de menor massa seus fragmentos, assumindo que a amostra seja um composto puro.

As amostras foram entregues liofilizadas para posterior ressuspensão na mistura de solventes clorofórmio:metanol 3:1. 
Resumo das informações das análises realizadas: Técnica de espectrometria de massa LC-MS de baixa resolução por infusão direta, com target de 1000 a $3000 \mathrm{~m} / \mathrm{z}$, no modo positivo e negativo.

Parâmetros de corrida:

- Capilaridade: $4000 \mathrm{~V}$

- Nebulização: 12,0 psi

- Gás seco: 5,0 L/min

- Temperatura de secagem: $300^{\circ} \mathrm{C}$ 


\subsection{Testes microbiológicos}

\subsubsection{Teste de esterilidade bacteriana e fúngica}

O teste foi empregado para confirmação da total ausência de contaminantes no produto final.

As amostras ressuspendidas em seu volume inicial de $10 \mathrm{~mL}$ foram inoculadas em tubos contendo meio de caseína de soja diluída e tioglicolato para verificação de contaminantes aeróbios e anaeróbios, mantidos por 14 dias em temperatura de $30^{\circ} \mathrm{C}$ a $35{ }^{\circ} \mathrm{C}$ para verificação de crescimento bacteriano e $20{ }^{\circ} \mathrm{C}$ a $25 \stackrel{\circ}{\mathrm{C}}$ para verificação de crescimento fúngico.

\subsubsection{Teste de endotoxina bacteriana - pirogênio in vitro ( $L A L)$}

O teste de endotoxina é o principal parâmetro para a qualidade microbiológica de fármacos e imunobiológicos, sendo o LAL (Limulus Amebocyte Lysate) o método mais utilizado para sua realização (FDA, 1987; MORALES, 2004).

Os ensaios foram realizados com $100 \mu \mathrm{L}$ de amostra pura e com a amostra nas diluições 1:10 e 1:100. A cada tubo de amostra foi adicionado $100 \mu \mathrm{L}$ do LAL (Padrão de Referência de Endotoxina USP, que tem uma potência definida de 10.000 Unidades de Endotoxina ou Unidades Endotóxicas (EU) por frasco), e mantidos em incubação a uma temperatura de $37^{\circ} \mathrm{C} \pm 1^{\circ} \mathrm{C}$, durante 60 minutos.

Durante este período foi verificada a formação de gel, invertendo-se o tubo em um ângulo de $180^{\circ}$. A formação do gel é o indicativo de resultado positivo para a presença de endotoxina, e a concentração desta é determinada de acordo com as diluições realizadas e expressas em $\mathrm{EU} / \mathrm{mL}$ (unidades endotóxicas por $\mathrm{mL}$ ). 


\subsection{Testes Biológicos (ensaios in vivo)}

\subsubsection{Teste de Toxicidade Específica}

As amostras foram ressuspendidas com solução fisiológica tamponada pH 6,8 para uma concentração final de $200 \mu \mathrm{g} / \mathrm{mL}$, sendo $0,5 \mathrm{~mL}$ de cada cada uma das amostras inoculado via intraperitoneal em 20 camundongos (14 a $16 \mathrm{~g}$ ) e outros 20 camundongos foram inoculados com igual volume de solução fisiológica tamponada $\mathrm{pH} 6,8$ (controle).

Foi marcado o peso inicial de cada animal e no $3^{\circ}$ e $7^{\circ}$ dia foi realizada uma nova pesagem. A variação do peso total do grupo durante este período foi calculada, adotando-se os seguintes critérios de aceitação: o peso total dos grupos não pode ser menor que o inicial e a variação de peso em relação ao inicial não pode ser menor que $60 \%$ da variação de peso do grupo controle, e nem ocorrer a morte dos animais inoculados.

\subsubsection{Teste de Toxicidade Inespecífica (Inocuidade)}

As amostras liofilizadas foram reconstituídas ao seu volume inicial com água para injetáveis, para uma concentração final de $1 \mathrm{mg} / \mathrm{mL}$. Foram selecionados 5 camundongos com peso entre 17 a $22 \mathrm{~g}$ para inoculação de $0,5 \mathrm{~mL}$ de produto (500 $\mathrm{\mu g} / \mathrm{dose}$ ) via intraperitoneal, e 5 camundongos determinados como grupo controle, foram inoculados com $0,5 \mathrm{~mL}$ de solução fisiológica $0,85 \%$ estéril.

Foi registrado o peso inicial dos animais de cada grupo, sendo realizada nova pesagem após 7 dias, observando-se se houve alguma alteração no estado de saúde destes animais. Ao final do período de 7 dias, para que o produto fosse considerado inócuo o peso dos animais deveria ser superior ao seu peso inicial. 


\subsubsection{Teste de Pirogênio in vivo}

O frasco contendo o produto foi ressuspendido com solução fisiológica apirogênica estéril para uma concentração final de $10 \mu \mathrm{g} / \mathrm{mL}$.

Foram selecionados e pesados 3 coelhos, sendo introduzido no reto dos animais eletrodos para verificação da temperatura inicial, que não foi maior que $1,0 \stackrel{\circ}{ } \mathrm{C}$ entre eles. Após a assepsia da região da orelha, foi inoculado $1 \mathrm{~mL} / \mathrm{Kg}$ peso de produto na veia marginal destes animais (sendo inoculado aproximadamente $30 \mu \mathrm{g}$ de produto em cada animal) e realizada a verificação da temperatura, em tempo zero, 3 e 9 horas.

Para que o produto fosse considerado apirogênico nenhum dos animais poderia apresentar aumento de temperatura igual ou superior a $0,5 \stackrel{\circ}{ } \mathrm{C}$ na somatória das variações individuais de todos não poderia exceder $1,3 \stackrel{\circ}{\circ}$. 


\subsection{Imunoensaio do tipo ELISA}

Este ensaio foi realizado para verificar a capacidade adjuvante de BpLipídioA através da detecção quantitativa dos anticorpos anti-HBs nas diferentes formulações vacinais preparadas com o este produto.

Para este ensaio foram selecionadas cinco formulações a serem testadas (Tabela 5).

Tabela 5 - Esquema das formulações vacinais a serem testadas quanto a sua atividade imunogênica. Cada uma das formulações foi preparada com o volume de $5 \mathrm{~mL}$.

\begin{tabular}{|c|c|c|c|c|}
\hline Grupus & $\begin{array}{c}\text { PHBsAg } \\
\text { [ ] }\end{array}$ & $\begin{array}{c}\text { Hidróxida de } \\
\text { alumínio Al(매 })_{3} \\
\text { [ ] }\end{array}$ & $\begin{array}{c}\text { BpLlpídio A } \\
\text { [ ] }\end{array}$ & $\begin{array}{c}\text { Soluçä́a salina } \\
\text { tamponada pH 6,8 } \\
\text { Volume }\end{array}$ \\
\hline 1 & I,25 $\mu \mathrm{g} / \mathrm{mL}$ & ----- & ----- & $4991 \mu \mathrm{L}$ \\
\hline 2 & l,25 $\mu \mathrm{g} / \mathrm{mL}$ & $0,5 \mathrm{mg} / \mathrm{mL}$ & ----- & $4746 \mu \mathrm{L}$ \\
\hline 3 & 0,625 $\mu \mathrm{g} / \mathrm{mL}$ & $0,5 \mathrm{mg} / \mathrm{mL}$ & $20 \mu \mathrm{g} / \mathrm{mL}$ & $4650 \mu \mathrm{L}$ \\
\hline 4 & 0,625 $\mu \mathrm{g} / \mathrm{mL}$ & ----- & $20 \mu \mathrm{g} / \mathrm{mL}$ & $48954 \mathrm{~L}$ \\
\hline 5 & ----- & ----- & $20 \mu \mathrm{g} / \mathrm{mL}$ & $4900 \mu \mathrm{L}$ \\
\hline 6 & ----- & ----- & ---- & $5000 \mu \mathrm{L}$ \\
\hline
\end{tabular}

Os animais foram divididos em 6 grupos de 7 animais cada, sendo estes inoculados via intraperitoneal com $0,5 \mathrm{~mL}$ de cada uma das formulações e o grupo controle foi inoculado com igual volume de solução salina tamponada $\mathrm{pH} \mathrm{6,8.} \mathrm{Os}$ animais permaneceram por 30 dias até a realização da sangria para verificação do título de anti-HBsAg, através da análise pela técnica de ELISA.

No teste de ELISA as amostras foram distribuidas na microplaca, juntamente com os controles positivo e negativo e um lote de Vacina recombinante contra hepatite B e uma Vacina recombinante contra hepatite B Referência, ambas produzidas no Instituto.

Às amostras foi adicionado o conjugado enzimático e homogeneizado por alguns segundos até a incubação a $37^{\circ} \mathrm{C}$ por 1 hora. Após esta etapa a microplaca foi submetida a lavagem com subsequente adição do substrato e incubação por 10 minutos a temperatura ambiente.Para bloquear a reação foi adicionada solução de parada e realizada a leitura em espectrofotômetro numa densidade óptica de $450 \mathrm{~nm}$. 


\subsection{Emulsões}

\subsubsection{Preparo da Emulsão IB}

As emulsões preparadas no IB, envolvem a dispersão óleo em água, sendo neste caso o óleo utilizado o esqualeno na concentração de $4 \%$ e o emulsionante Tween 80 a 0,4\%. O adjuvante bacteriano (BpLipídioA) foi adicionado à formulação na concentração de $20 \mu \mathrm{g} / \mathrm{mL}, 100 \mu \mathrm{g} / \mathrm{mL}$ e $400 \mu \mathrm{g} / \mathrm{mL}$. As concentrações finais destes componentes já foram descritas na literatura (O'Hagan, 2000).

Para um volume teórico final de emulsão de $1000 \mathrm{~mL}$, foi aspirado $40 \mathrm{~mL}$ de esqualeno em uma seringa e reservado até o momento de sua adição na fase aquosa. Para o preparo da fase aquosa foi utilizado Tween 80 e tampão fosfato $\mathrm{pH}$ 7,4 , e subsequente adição do BpLipídioA. A fase aquosa e o esqualeno foram colocados no equipamento Microfluidizer ${ }^{\circledR}$ e iniciada a emulsificação e determinação do número de passagens ou ciclos necessários para o processo.

Após a emulsificação, as emulsões foram filtradas $(0,22 \mu \mathrm{m})$ e submetidas à análise do tamanho de suas partículas bem como da distribuição destas através da dispersão dinâmica da luz (DLS) utilizando o equipamento Malvern Zetasizer NanoS. Outros testes para controle de qualidade das emulsões como: esterilidade bacteriana e fúngica, determinação de endotoxina bacteriana $(L A L)$, toxicidade inespecífica, $\mathrm{pH}$ e pirogênio in vivo foram realizados (Figura 9). Para o estudo da estabilidade destas emulsões foram analisados os parâmetros de separação de fases (aspecto visual) ao longo do tempo, bem como o tamanho das partículas e sua distribuição.

O testes de separação de fase (aspecto visual), foi realizado durante um seis meses, como forma de verificar a estabilidade desta emulsão ao longo deste período, as amostras foram mantidas em câmara fria de 2 a $8{ }^{\circ} \mathrm{C}$ e a temperatura ambiente $25^{\circ} \mathrm{C} \pm 1{ }^{\circ} \mathrm{C}$.

A análise do tamanho das partículas e sua distribuição também foi realizada durante o mesmo período, a fim de verificar se houveram alterações que pudessem comprometer a qualidade desta emulsão. 


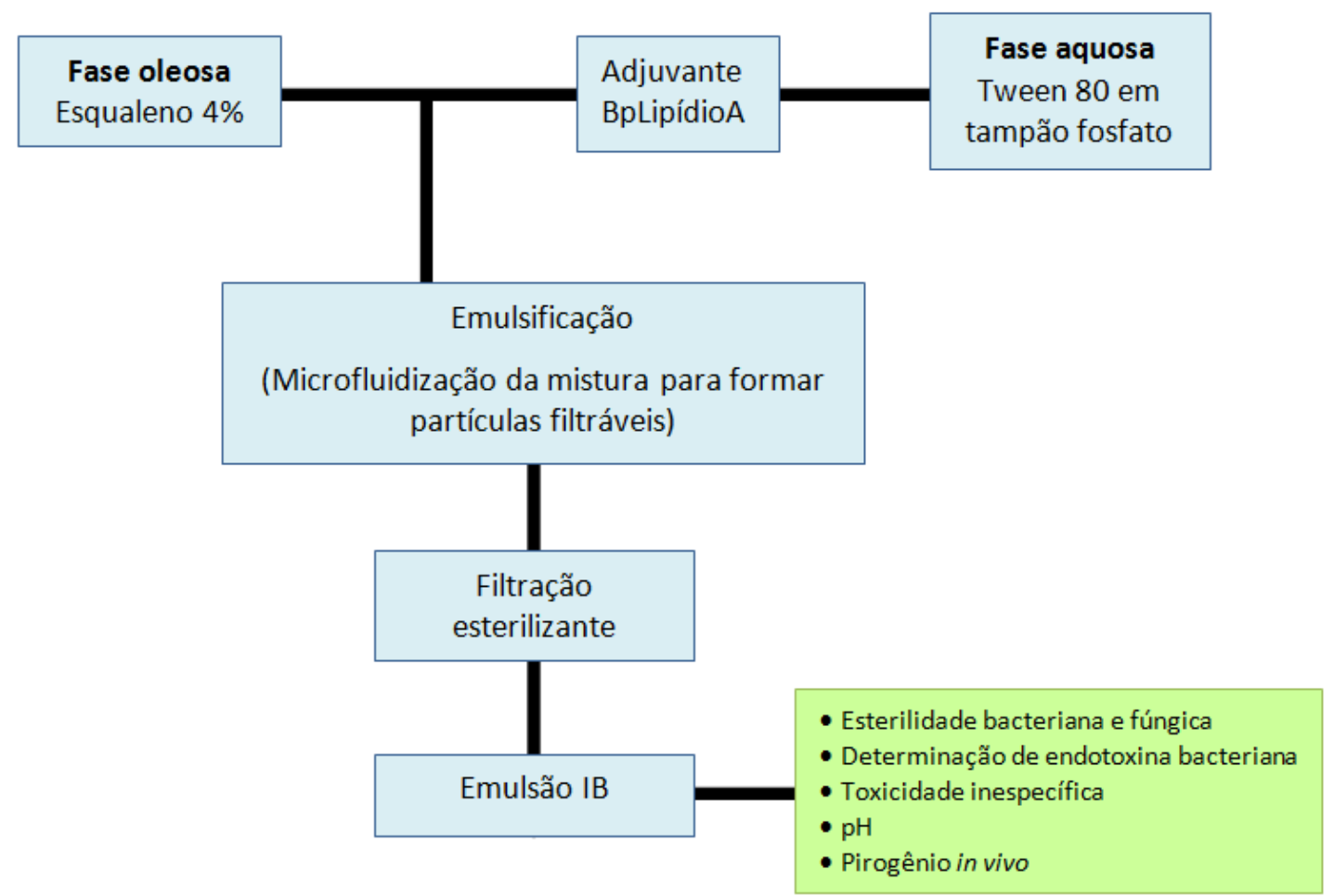

Figura 9: $\square$ Etapas de preparo da emulsão IB. $\square$ Testes para controle do processo realizados nas emulsões. 


\section{CAPÍTULO IV}

\section{RESULTADOS E DISCUSSÃO}

\subsection{Caracterização do produto}

O LPS extraído da Bordetella pertussis, utilizada na produção da vacina contra coqueluche, pode originar um provável adjuvante para diferentes formulações de um mesmo antígeno vacinal e/ou de outros antígenos.

Estudos preliminares com diferentes processos extrativos e de purificação permitiram obter um produto basicamente composto por espécies iônicas tetraciladas de um lipídio A monofosforilado (BPMPLA), que apresentou ação adjuvante para o vírus da influenza, permitindo a redução de até 4 vezes a dose do antígeno vacinal e ainda conferindo imunidade protetora com um perfil mais favorável de ambas respostas imune humoral e celular (QUINTILIO et al., 2009).

Entretanto $O$ fato de $\mathrm{O}$ produto ser basicamente tetracilado recebeu questionamentos quanto a ativação do receptor TLR4, que reconhece o LPS induzindo uma cascata de sinalização para produção de citocinas pró-inflamatórias, sendo que o lipídio A com menor número de cadeias aciladas, induz uma ineficiente resposta imunoestimulatória tanto humoral quanto celular (Figura 10).

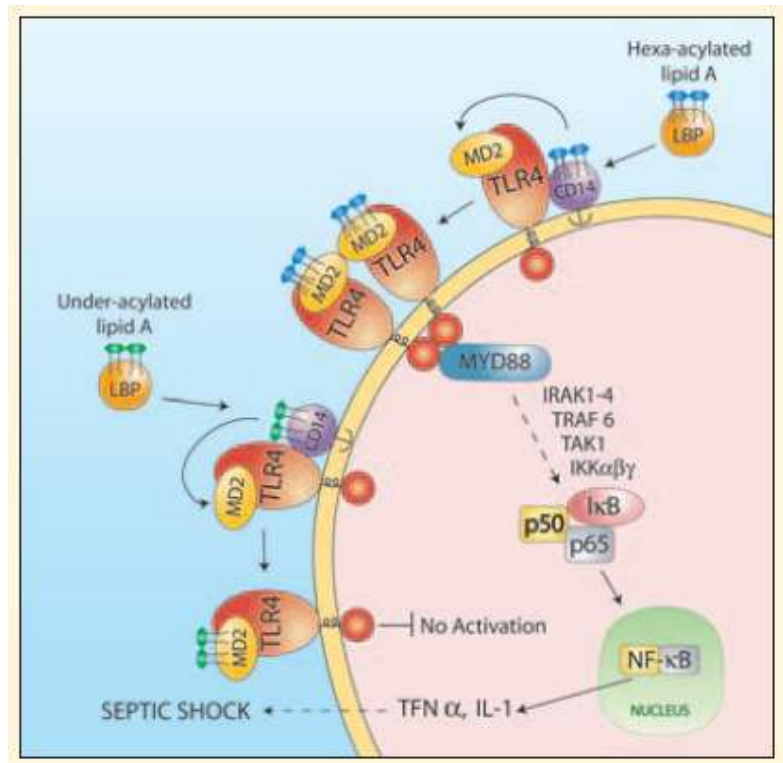

Figura 10: Atividade do lipídio A hexacilado e de um lipídio $A$ hidrolizado com menor número de cadeias aciladas. FONTE: Invivogen Insight (2007). 
Cada uma das amostras do produto Lipídio A de B. pertussis analisada foi denominada como lote, seguido do número sequencial de acordo com a data de sua fabricação e a sigla BpLpA para sua identificação.

Foram realizadas algumas alterações nas etapas de produção, visando a obtenção de um produto final com maior número de cadeias aciladas, e uma maior abundância de espécies pentaciladas do que tetraciladas, como demonstrado na figura 11.

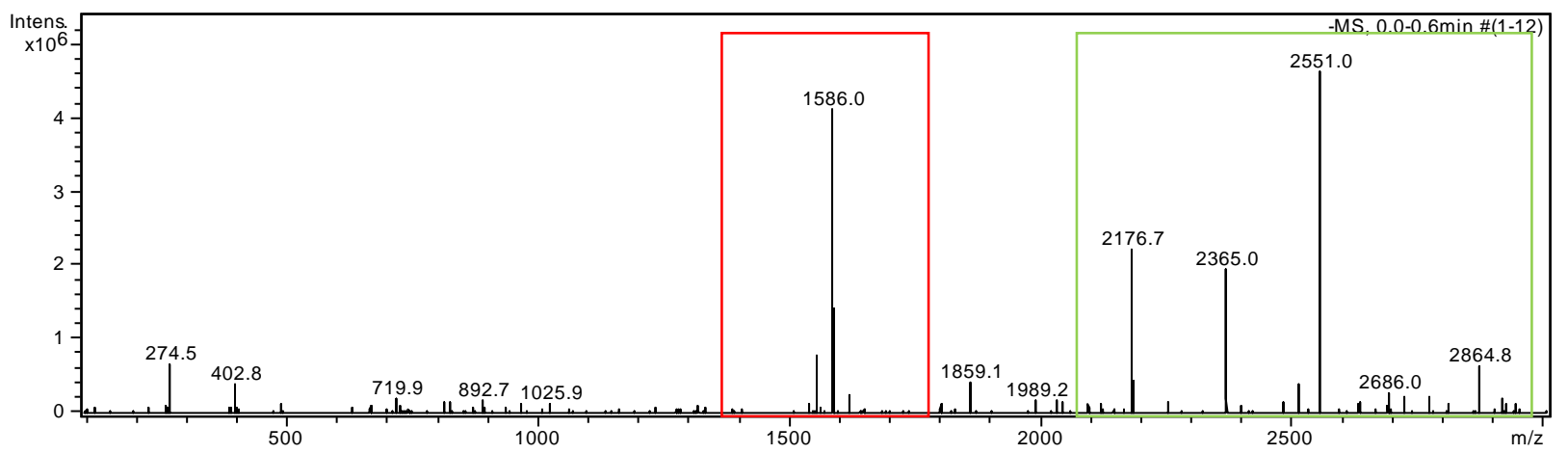

Figura 11: Espectrometria de massa de um lote de BpLipídioA com alteração de metodologia para obtenção de espécies pentaaciladas. $\square$ Pentacilada Resíduos de LOS.

Esta alteração está relacionada ao tempo de hidrólise com ácido acético empregado no processo produtivo, necessário para a remoção da parte hidrofóbica da molécula de LPS, que é considerada a responsável pela atividade endotóxica do Lipídio A (CAROFF et al., 1986; CAROFF; TACKEN; SZABÓ, 1988).

A análise do teste de endotoxina bacteriana ( $L A L)$, apresentou resultados entre 0,125 e 1,25 UE/mL, sendo observado um aumento destes valores nos últimos lotes produzidos, mas todos dentro de um limite aceitável para sua aplicação em vacinas. Por exemplo, para a vacina polissacarídica menigocócica grupos $\mathrm{A}$ e $\mathrm{C}$ em uma dose de 0,05 $\mathrm{\mu g}$ (dose) $100 \mathrm{UE} / \mathrm{mg}$ é o limite (FDA/GUIDELINE ON VALIDATION of LAL, 1987). 
Tabela 6 - Resultados dos testes de endotoxina bacteriana para os 7 lotes analisados.

\begin{tabular}{ccc}
\hline \hline Lotes & \multicolumn{1}{c}{ Resultada UE/mL* } \\
\hline \hline $1 / \mathrm{LpA}$ & $>12,5 \mathrm{EU} / \mathrm{mL}$ & $<125 \mathrm{EU} / \mathrm{mL}$ \\
$2 / \mathrm{LpA}$ & $>0,125 \mathrm{EU} / \mathrm{mL}$ & $<1,25 \mathrm{EU} / \mathrm{mL}$ \\
$3 / \mathrm{LpA}$ & $>1,25 \mathrm{EU} / \mathrm{mL}$ & $<12,5 \mathrm{EU} / \mathrm{mL}$ \\
$4 / \mathrm{LpA}$ & $>0,125 \mathrm{EU} / \mathrm{mL}$ & $<1,25 \mathrm{EU} / \mathrm{mL}$ \\
$5 / \mathrm{LpA}$ & $>0,125 \mathrm{EU} / \mathrm{mL}$ & $<1,25 \mathrm{EU} / \mathrm{mL}$ \\
$6 / \mathrm{LpA}$ & $>1,25 \mathrm{EU} / \mathrm{mL}$ & $<12,5 \mathrm{EU} / \mathrm{mL}$ \\
$7 / \mathrm{LpA}$ & $>1,25 \mathrm{EU} / \mathrm{mL}$ & $<12,5 \mathrm{EU} / \mathrm{mL}$ \\
${ }^{*}$ Unidades Endotóxicas por $\mathrm{mL}$ & \\
\hline
\end{tabular}

A redução da atividade endotóxica é esperada para produtos derivados de LPS, como descrito num estudo realizado por Gao et al. em 2006, onde foi demonstrado que o LPS de bactérias Gram negativas tem significativa perda de sua atividade endotóxica quando submetido a fervura a $100 \stackrel{\circ}{ } \mathrm{C}$, mantendo sua capacidade adjuvante.

O tempo de hidrólise é um fator crucial para que haja completa liberação da molécula de KDO fosforilada do Lipídio $\mathrm{A}$. Os produtos que apresentaram uma maior quantidade de resíduos de ligooligossacárides (LOS) ao final do processo (Figura 11) são os que podem apresentar maior quantidade de KDO no produto final (tabela 7). Os lotes 1/LpA e os últimos lotes produzidos 6/LpA e 7/LpA, apresentaram 14,53, 15,42 e 14,61 $\mu \mathrm{g} / \mathrm{KDO}$ respectivamente.

Tabela 7 - Resultado da dosagem de KDO pela técnica com reativo de Purpald $^{\circledR}$, quantificando resíduos de KDO no produto final. Na dosagem realizada, todas as amostras tiveram valores abaixo de $1 \%$, percentual aceito para liberação do produto.

\begin{tabular}{|c|c|c|c|}
\hline \multirow{2}{*}{$\begin{array}{l}\text { Lotes } \\
\text { (BpLpA) }\end{array}$} & \multicolumn{3}{|c|}{ KDO (Purpald } \\
\hline & $\mathrm{mM}$ & $\mu \mathrm{g} / \mathrm{mL}$ & $\%$ \\
\hline I/ LpA & 0,057 & 14,53 & $<1$ \\
\hline 2/LpA & 0,021 & 5,34 & $<1$ \\
\hline 3/LAA & 0,037 & 9,39 & $<1$ \\
\hline 4/LpA & प, प13 & 3,19 & $<1$ \\
\hline $5 /$ LpA & 0,033 & 8,53 & $<1$ \\
\hline G/LpA & 0,060 & 15,42 & $<1$ \\
\hline 7/LpA & 0,057 & $\mid 4,61$ & $<1$ \\
\hline
\end{tabular}


As concentrações de LPS e dos seus derivados (Lipídios A) de H. influenzae, $B$. pertussis e $V$. cholerae não podem ser determinadas pela correlação da dosagem de KDO pela técnica de Osborn (ácido tiobarbitúrico), mas somente pela técnica com o reativo de Purpald ${ }^{\circledR}$ (LEE; TSAI, 1999). A metodologia do ácido tiobarbitúrico não se aplicaria para o Lipídio $A$ de Bordetella pertussis porque o único KDO livre e reativo após hidrólise teoricamente seria zero e não poderia ser detectado devido às suas substituições nas posições C-4 e C-5 não suscetíveis a digestão ácida (LEE; TSAI, 1999). Nossos dados comprovaram este fato também para a linhagem de $B$. pertussis utilizada neste trabalho (Bordetella pertussis cepa 137; 4.21.83).

O ensaio com o reativo de Purpald ${ }^{\circledR}$ é superior em pelo menos dois importantes aspectos, primeiro em termos operacionais, devido a não necessidade de hidrólise e de fervura durante as etapas, permitindo que o ensaio seja realizado em microplacas e na temperatura ambiente, e principalmente, porque é aplicável ao LPS de um grande número de bactérias, desde que contenham KDO e heptoses. Para o LPS de Bordetella pertussis o ensaio detecta as 2 heptoses (incluindo uma presente no core externo), a outra heptose e o KDO presentes no core interno (LEE; TSAI, 1999; GEURTSEN, 2007).

O LPS de Bordetella pertussis cepa 137 da amostra inicial foi portanto quantificado por Purpald ${ }^{\circledR}$, pela correlação do KDO presente nesta molécula (3:1).

Tabela 8 - Valores da dosagem de KDO quantificando de maneira indireta o LPS presente na matériaprima que será utilizada na produção do BpLpA.

\begin{tabular}{|c|c|c|}
\hline \multirow{2}{*}{$\begin{array}{c}\text { Filtrado } \\
\text { LPS }\end{array}$} & \multicolumn{2}{|c|}{ KDD (Purpald $\left.{ }^{\mathbb{1}}\right)$} \\
\hline & $\mathrm{mM}$ & $\mu \mathrm{g} / \mathrm{mL}$ \\
\hline 05/09 & 0,162 & 41,30 \\
\hline 听/09 & 0,076 & 19,32 \\
\hline DI/10 & 0,III & 28,42 \\
\hline Q2/10 & 0,057 & 14,49 \\
\hline Q3/10 & 0,104 & 26,51 \\
\hline प5/10 & 0,118 & 30,18 \\
\hline Q6/10 & Q,III & 28,26 \\
\hline
\end{tabular}


Quando ainda é possível detectar KDO no produto final isto indicaria provável não fragmentação do core interno e portanto o fósforo poderia também ser quantificado nesta estrutura e não apenas na fração lipídica. A hidrólise ácida em altas temperaturas produz um Lipídio $A$ com pelo menos $80 \%$ do fosfato ácido lábil removido (CAROFF; TACKEN; SZABÓ, 1988). O fluxograma de fragmentação da endotoxina de $B$. pertussis por tratamento ácido apresentado por Le Dur e colaboradores em 1980, já apresentava estes resultados, mas ainda seria necessário aumentar o tempo da hidrólise (30 para 60 minutos ou mais) para que PS II com Kdo fosforilado não estivesse mais presente (Figura 12).

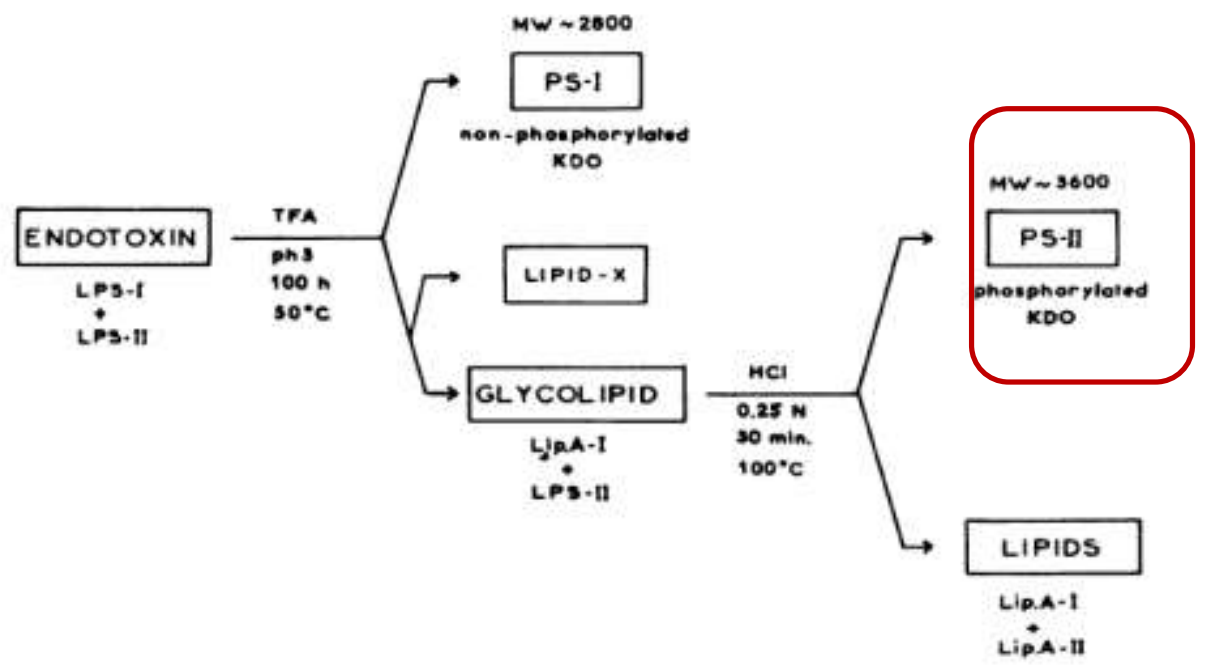

Figura 12: Fração PS-II com a molécula de KDO fosforilada (retângulo vermelho) e fração lipídica.

FONTE: Le Dur, Chaby e Szabo (1980).

As tabelas 9 e 10 indicadas a seguir, apresentam respectivamente a quantidade de fósforo e de proteínas nos produtos finais analisados. Os lotes 1/LpA e 6/LpA apresentaram concentrações similares de fosforo e de KDO conforme demonstrado na tabela 7, mas apresentaram a maior diferença de percentual de proteínas $(0,96 \%$ e $2,65 \%)$. Os lotes $2 / \mathrm{LpA}$ e $3 / \mathrm{LpA}$ apresentaram percentuais proteicos similares e diferiram no KDO e no fósforo. Os lotes 3/LpA e 4/LpA apresentaram valores similares de fósforo, proteínas e valores diferentes para 0 KDO. As variações observadas foram provavelmente geradas por alterações propositais em etapas do processo produtivo, incluindo matéria prima inicial, com objetivos definidos para obtenção de produto final puro com as características de um lipídio A destoxificado e com maior rendimento, mas que poderiam gerar também 
residual de KDO fosforilado e/ou incorporação de proteínas fosforiladas ao final do processo (LEIVE; SHOVLIN, 1968; MORRISON; BETZ; JACOBS, 1976).

Tabela 9 - Resultados da dosagem de fósforo de todos os lotes.

\begin{tabular}{|c|c|}
\hline Lote & $\begin{array}{c}\text { Fósforo (P) } \\
\text { Concentração } \\
\text { (нg P/mg LpA) }\end{array}$ \\
\hline 1/LpA & 389 \\
\hline 2/LpA & 799 \\
\hline 3/LpA & 215 \\
\hline 4/LpA & 217 \\
\hline 5/LpA & 485 \\
\hline G/LpA & 326 \\
\hline 7/LpA & 306 \\
\hline
\end{tabular}

Tabela 10 - Resultados da dosagem de proteína, concentração e porcentagem relativa no produto final.

\begin{tabular}{c|c|c}
\hline \multirow{3}{*}{ Lote } & \multicolumn{2}{c}{ Proteína } \\
\cline { 2 - 3 } & \multicolumn{2}{c}{$\begin{array}{c}\text { Concentraçãu } \\
(\mu \mathrm{g} / \mathrm{mL})\end{array}$} \\
\hline I/LpA & 98,1 & $0,96 \%$ \\
\hline 2/LpA & 202,8 & $2,41 \%$ \\
\hline $3 / \mathrm{LpA}$ & 210,7 & $2,09 \%$ \\
\hline 4/LpA & 212,4 & $2,08 \%$ \\
\hline $5 / \mathrm{LpA}$ & 160,0 & $1,60 \%$ \\
\hline 6/LpA & 265,5 & $2,65 \%$ \\
\hline $7 / \mathrm{LpA}$ & 222,0 & $2,20 \%$ \\
\hline
\end{tabular}

A utilização da espectrometria de massa neste trabalho objetivou identificar nos espectros obtidos, espécies iônicas já descritas e relacionadas com a composição da estrutura molecular da endotoxina. Esta poderosa e complexa tecnologia tem sido empregada por inúmeros autores fornecendo "a impressão digital" de vários microorganismos incluindo a Bordetella pertussis (CAROFF et al., 1994; 2000; CAROFF; KARIBIAN, 2003; GEURTSEN, 2007; TIRSOAGA et al., 2007; MARR et al., 2008; EL HAMID et al., 2009, GEURTSEN et al., 2009, MARR et al., 2010). A figura 13 resume as espécies iônicas descritas para Bordetella pertussis (MARR et al., 2010). 


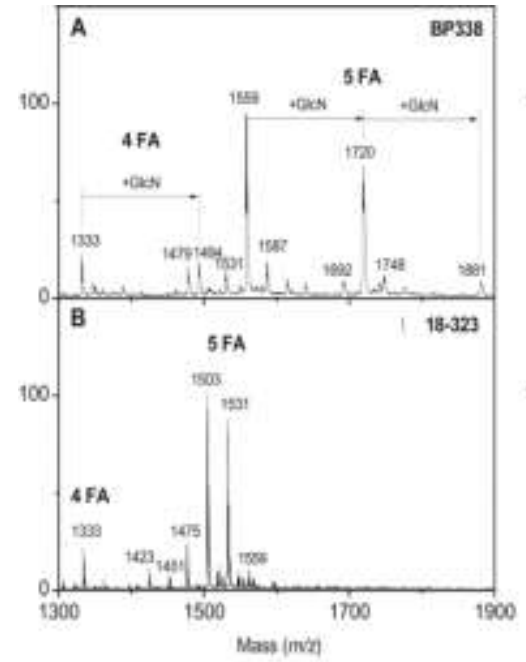

E

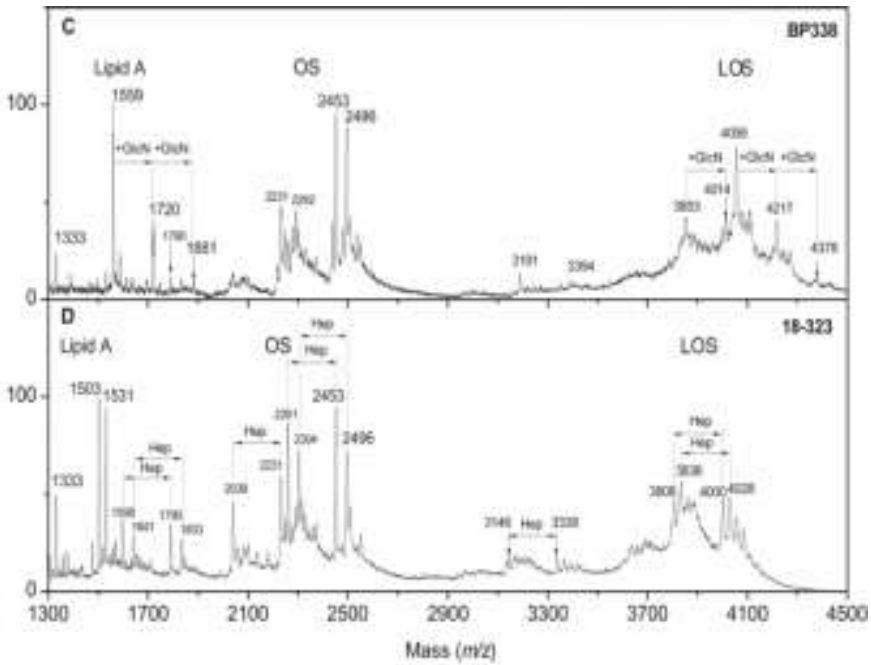

18-323
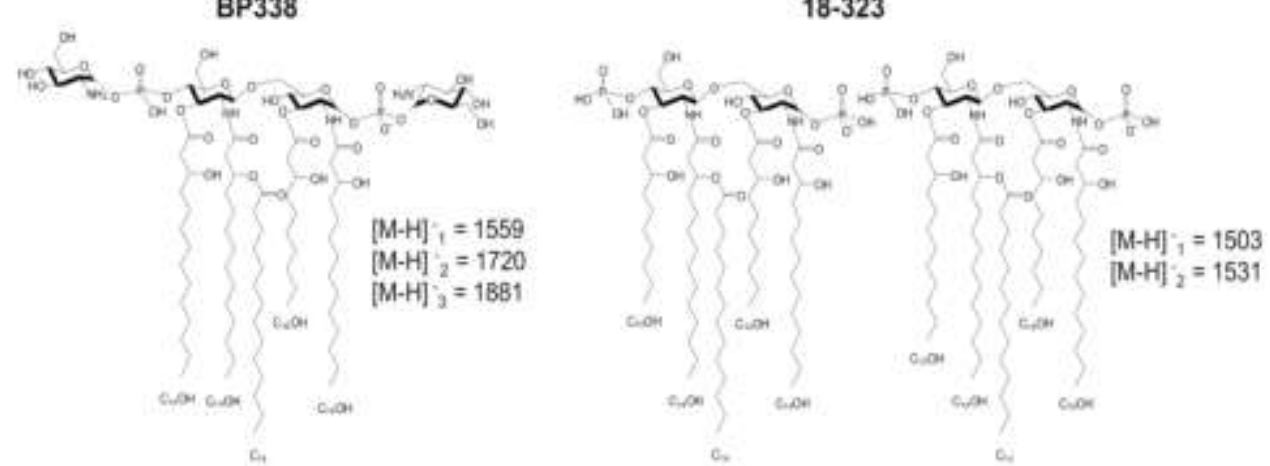

Figura 13: Espectros de massa do Lipídio $A$ e do lipooligossacarídio (LOS) de Bordetella. Os painéis A e B mostram os espectros do lipídio A de B. pertussis, linhagens 338 e 18-323, respectivamente; apresentando espécies tetra (4FA) e pentaaciladas (5FA). Painéis C e D descrevem os espectros de LOS. Painel E apresenta estruturas pentaaciladas com incorporações de uma ou mais glicosaminas (esquerda) ou de estruturas sem incorporação de glicosamina mas que apresentam na posição C-3 do arcabouço das duas glicosaminas cadeias aciladas hidroxiladas de 12 ou de 10 carbonos no lugar de uma de 14.

FONTE: Marr et al. (2010).

A espectrometria de massa dos lotes produzidos demonstrou que o aumento da abundância relativa das espécies iônicas acima de $2000 \mathrm{~m} / \mathrm{z}$, podem ser fragmentos originados de LOS, como aqueles verificados nos lotes 6/LpA e 7/LpA (Figura 14) e corrobora com os dados apresentados na dosagem de KDO (Tabela 7), mas pode acrescentar que provavelmente a metodologia de produção do lote 1/LpA (concentrações similares de KDO e fósforo, porém com baixo percentual de proteínas) deve ser selecionada em detrimento daquela que produziu lotes como os lotes 6/LpA e 7/LpA se comparados com o lote 1/LpA, praticamente composto por $80 \%$ de espécies tetra e pentaaciladas características do Lipídio A de Bordetella pertussis (Figura 14). 
Os lotes analisados apresentaram-se heterogêneos com a presença de espécies triaciladas, tetraciladas e pentaciladas (lotes 2/LpA, 5/LpA, 6/LpA e 7/LpA).

Os lotes $1 / \mathrm{LpA}, 3 / \mathrm{LpA}$ e $4 / \mathrm{LpA}$ com predominância de espécies tetra e pentaaciladas. A abundância relativa destas espécies no produto total está representada na figura 14 .

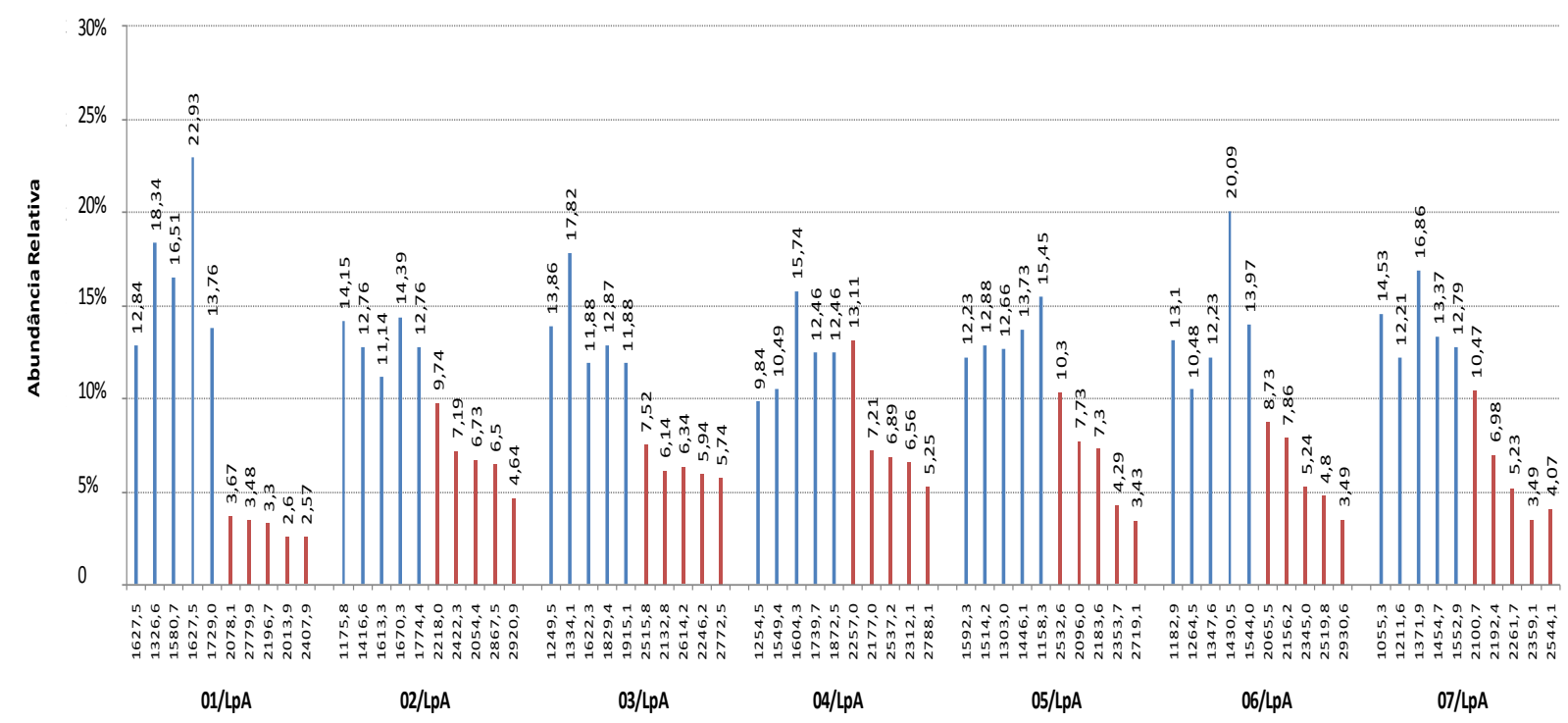

Figura 14: Análise da abundância relativa das espécies iônicas predominantes e dos fragmentos de LOS nos 7 lotes analisados. Espécies iônicas predominantes; fragmentos de LOS.

Os dados da tabela 11 apresentam as cinco principais espécies iônicas encontradas na espectrometria de massa para os produtos analisados, a faixa de interesse do nosso produto encontra-se entre numa relação m/z de 1000 a 2000 . Sinais acima deste valor podem ser considerados fragmentos de LOS parcialmente hidrolizados ou espécies iônicas de Lipídio A geradas por incorporação de outros compostos como açúcares e/ou cadeias aciladas (MARR et al., 2008, 2010) (Figura 13). A Bordetella pertussis sob situação de extremo "stress" durante seu crescimento, pode produzir mais uma cadeia acilada, apresentando-se como hexacilada com massas acima de $1580 \mathrm{~m} / \mathrm{z}$ (GEURTSEN et al., 2009). 


\begin{tabular}{|c|c|c|c|c|c|}
\hline bela 11 & \multicolumn{5}{|c|}{$\begin{array}{l}\text { Representação das } 5 \text { espécies iônicas } \\
\text { predominantes nos lotes analisados, dentro da } \\
\text { faixa de } \mathrm{m} / \mathrm{z} \text { de } 1000 \text { a } 2000 \text {. }\end{array}$} \\
\hline \multirow{2}{*}{$\frac{\text { Lotes }}{1 / \text { LpA }}$} & \multicolumn{5}{|c|}{ Espécies iônicas predaminates (m/z) } \\
\hline & 1627,5 & 1326,6 & 1580,7 & 1627,5 & 1729,0 \\
\hline 2/LpA & 1175,8 & 146,6,6 & $|6| 3,3$ & 1670,3 & 1774,4 \\
\hline 3/LpA & 1249,5 & 1334,1 & 1622,3 & 1829.4 & 1915,1 \\
\hline 4/LpA & 1254,5 & 1549,4 & 1604,3 & 1739,7 & 1872,5 \\
\hline $5 / \mathrm{LpA}$ & 1592,3 & 1514,2 & 1303,0 & 1446,1 & 11158,3 \\
\hline 6/LpA & 1182,9 & 1264.5 & 1347,6 & 1430,5 & 1544,0 \\
\hline 7/LpA & 1055,3 & I211,6 & 1371,9 & 1454,7 & 1552,9 \\
\hline
\end{tabular}

Estas espécies iônicas que compõem o produto se apresentam numa determinada intensidade no espectro, proporcional à concentração deste na amostra analisada. A figura 15 compara as 5 espécies iônicas de maior intensidade na análise de cada um dos lotes.

Condições de hidrólise brandas ou muito drásticas (LE DUR; CHABY; SZABO, 1980; EL HAMIDI et al., 2005, 2009) ou mesmo a fonte do LPS (por exemplo, filtrado de sobrenadante de cultivo bacteriano com menor rendimento expresso em unidades opaciométricas $/ \mathrm{mL}$ ) pode como já discutido influenciar a evidência dos resultados em termos da espécies iônicas e intensidades observadas que não seriam apenas fruto das técnicas de purificação e análise mas também oriundas até da genética e do metabolismo bacteriano (GEURTSEN et al., 2009). 


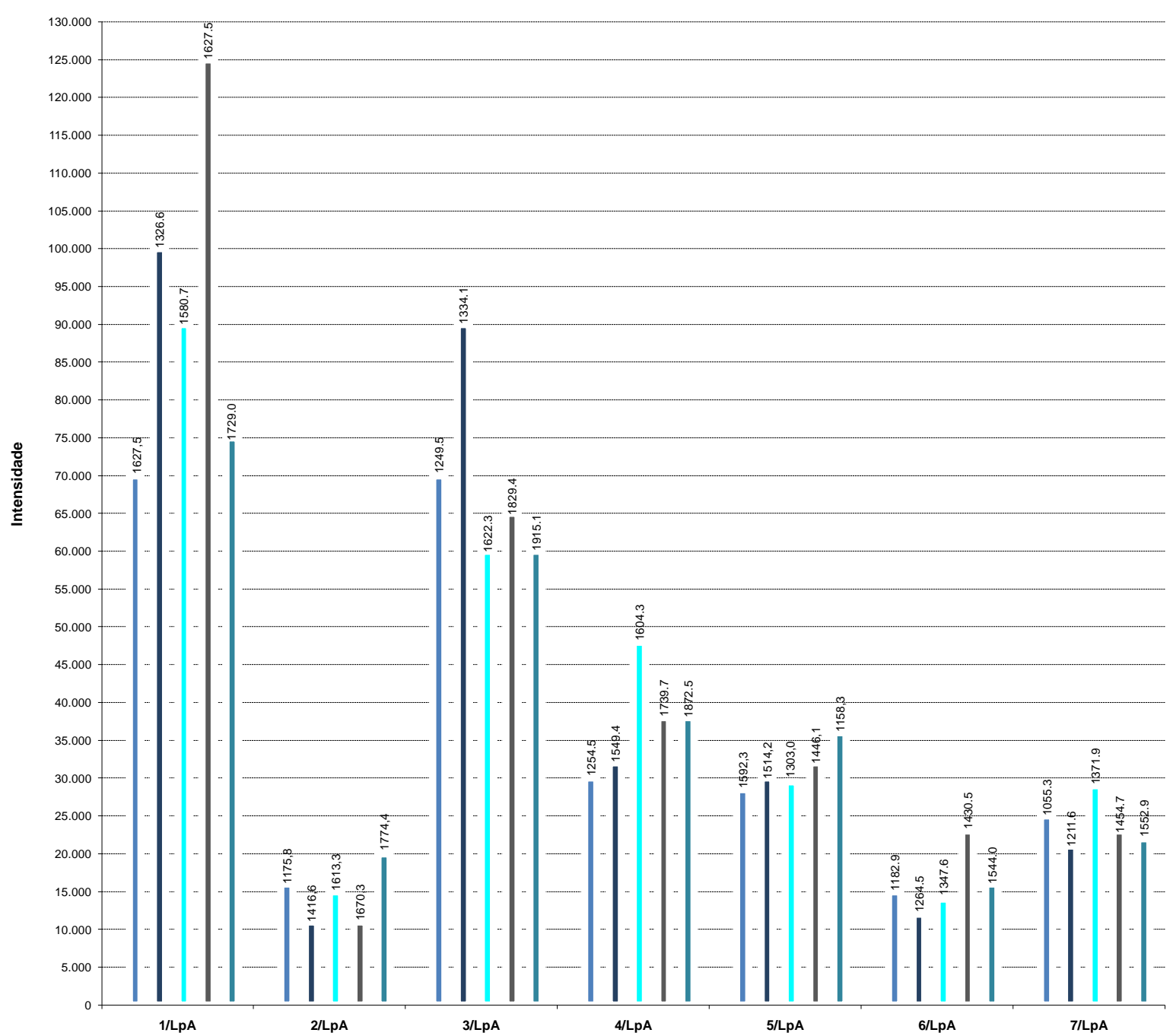

Figura 15: Intensidade das principais espécies iônicas dos 7 lotes analisados.

Os procedimentos de extração branda realizados na presença de detergentes e/ou hidróxido de amônio (métodos alcalinos) obtiveram resultados com menor degradação ou fragmentação se comparado ao lipídio A obtido por hidrólise com ácido acético pela perda de grupos fosfato das duas principais espécies moleculares com picos de m/z de 1252 e 1478 (Figura 16). A opção pela hidrólise drástica explicaria a maior variabilidade de espécies iônicas inclusive de menor intensidade na faixa de interesse encontradas nos lotes de BpLipídioA analisados (Tabela 11, Figuras 15 e 17). 


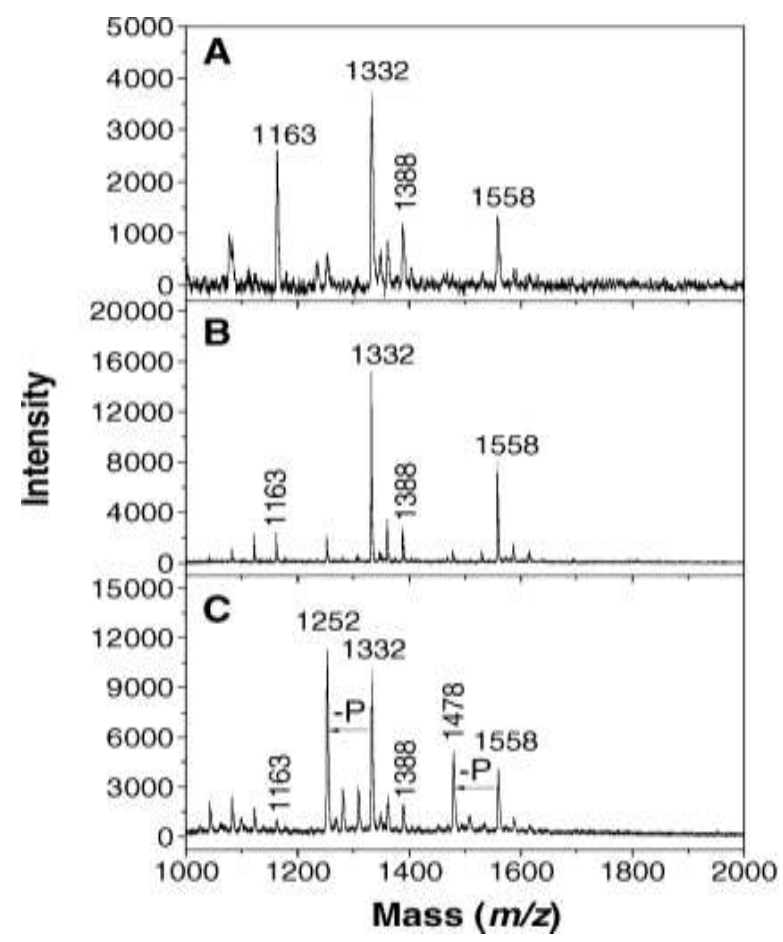

Figura 16: Perfil da espectrometria de massa do lipídio A de Bordetella pertussis obtido por diferentes metodologias. (A) hidrólise por ácido butírico e hidróxido de amônio, (B) hidrólise com SDS e pH de 4,5 e (C) hidrólise com ácido acético.

FONTE: El Hamidi et al. (2005).

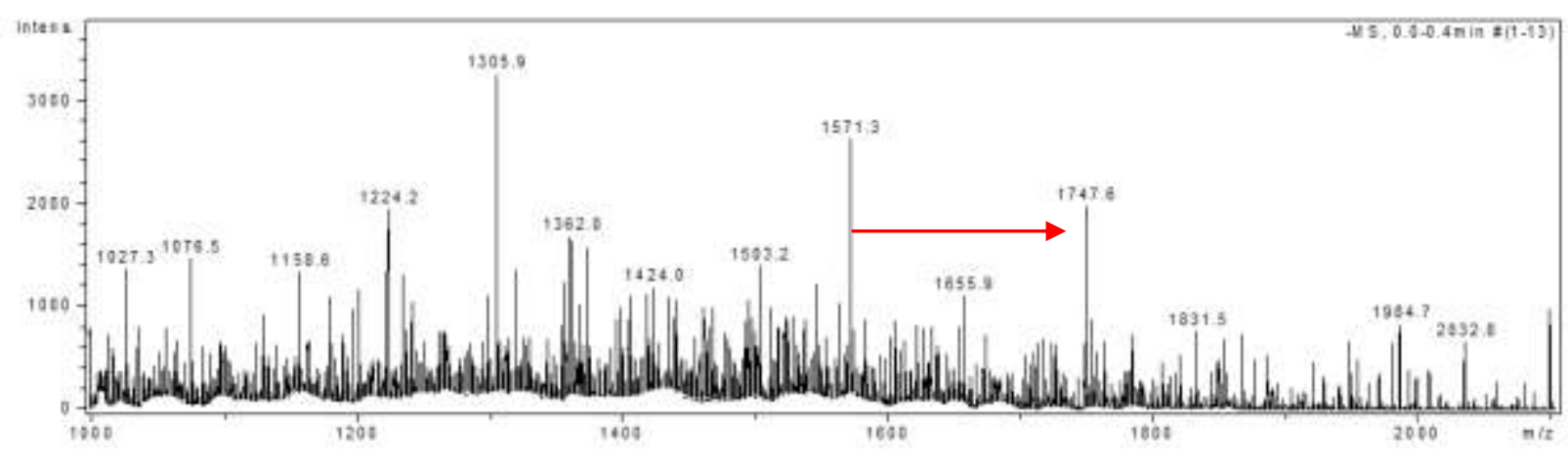

Figura 17: Espectro de massa do Lipídio A de Bordetella pertussis obtido por hidrólise ácida com predominância de espécies tri, tetra e pentaciladas. A seta poderia indicar incorporação de açúcares Marr et al. (2010), como mostrado no painel C da figura 13.

A análise de todos os lotes apresentou uma maior abundância das espécies iônicas na faixa de interesse para o produto em relação aos fragmentos de LOS. As espécies representativas do produto apresentaram percentual de abundância relativa entre 9,84 a 26,09\%, enquanto a abundância dos fragmentos de LOS ficou numa faixa de 2,57 a 10,47 \% (Figura 18). 


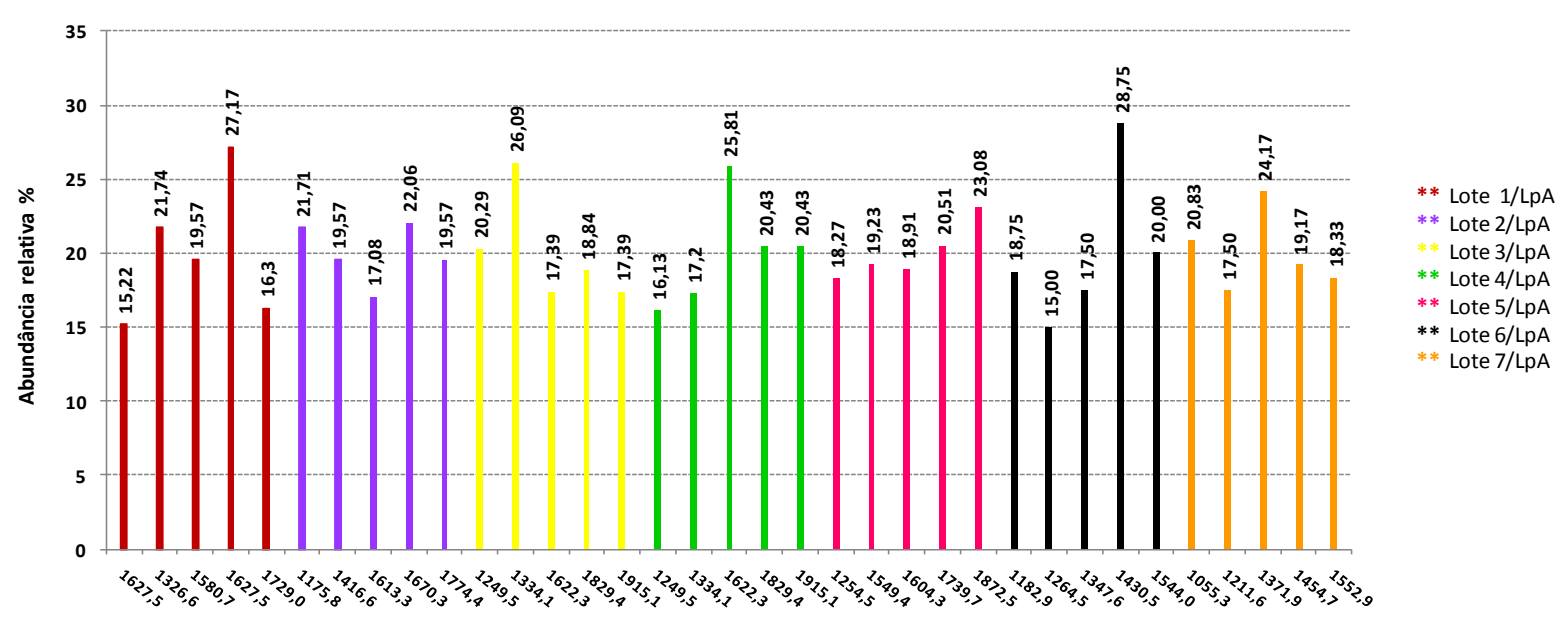

Figura 18: Abundância relativa das espécies iônicas dos 7 lotes analisados.

A figura 19 apresenta a comparação de hidrólises do LPS de B. pertussis. Menor degradação foi observada com os métodos $A$ e $B$, (métodos alcalinos) comprovado pela ausência de produtos de migração mais rápida $(\mathrm{m} / \mathrm{z}$ de 1252 e 1478) correspondentes as principais espécies de lipídio A que perderam seus grupos fosfatos observadas apenas em $C$ (ácido acético 1\%, por 90 minutos a $100{ }^{\circ} \mathrm{C}$ ) (EL HAMIDI et al., 2005). Caroff et al. (1986) já tinham descrito esta degradação para processo hidrolítico com $0,25 \mathrm{~N}$ de $\mathrm{HCl}$ e a descreveram como mistura de fragmentos derivados da estrutura original onde todos os compostos teriam perdido o fosfato glicosídico e alguns ácidos graxos ácido-lábeis, resultando na heterogeneidade das espécies iônicas observadas nos espectros de massa. 
(I)

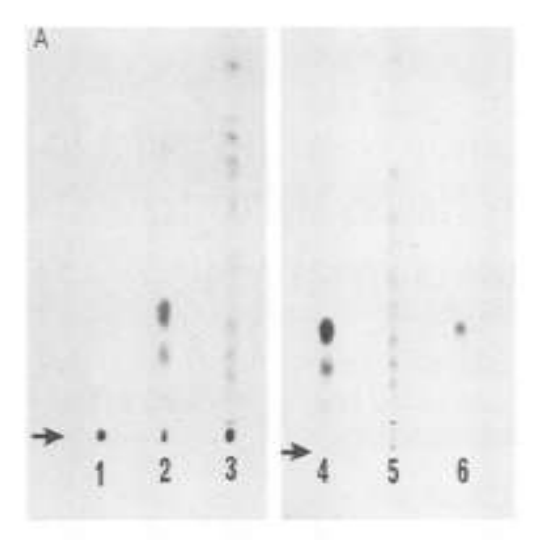

(II)

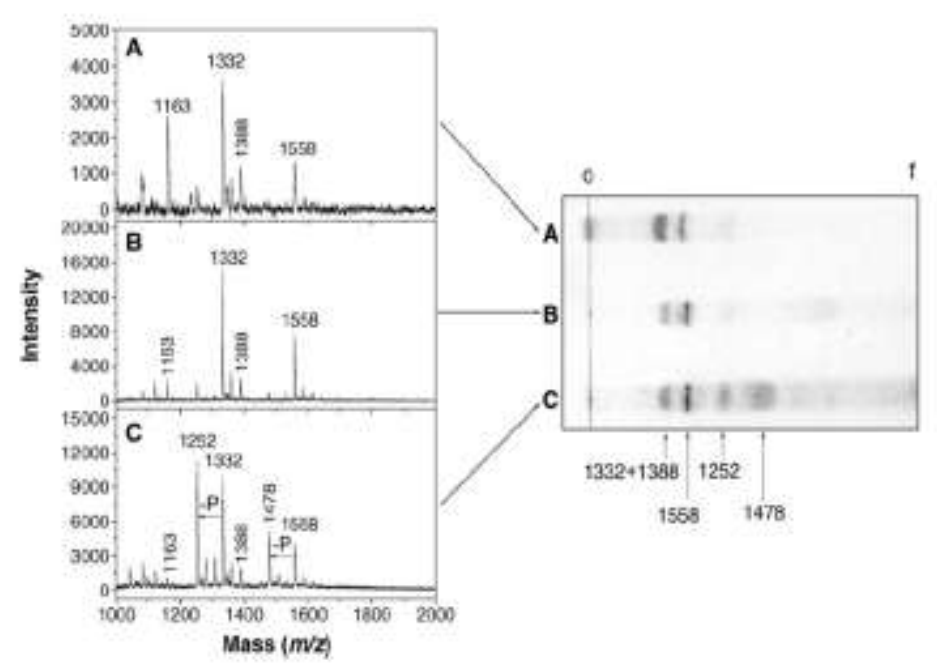

Figura 19: (I) TLC do LPS e Lipídio A de B.pertussis (A) 1. LPS; 2. Lipídio A bruto (método alcalino); 3. Lipídio $\mathrm{A}$ bruto (método $0,25 \mathrm{~N}$ de $\mathrm{HCl}$ ); 4. Lipídio A purificado (método alcalino); 5 . Lipídio A purificado (método $0,25 \mathrm{~N} \mathrm{HCl}$ ) 6. Lipídio A homogêneo (método $0,25 \mathrm{~N} \mathrm{HCl}$ ) (TLC preparativa) (Figura extraída de Caroff et al, 1986). (II) TLC apresentando espécies moleculares identificadas pelas massas correspondentes.

FONTE: El Hamidi et al. (2005).

Uma TLC preparativa permite portanto discriminar Lipídios A mono e difosforilados e até quantificá-los monitorando a cinética da hidrólise (EL HAMIDI et al., 2005).

A TLC apresenta o perfil dos lotes de BpLipídioA, similar ao descrito por Caroff et al. (1994) (figura 20 (I) e (II)). Uma análise visual rápida da placa de TLC realizada com o produto mostra que os Lotes 1 , 2, 3, 4 e 6/LpA são similares entre si e com o padrão LpA. Já os lotes 5 e 7/LpA são similares ao FM (ainda LPS ou LOS). Os lotes 5 e 7 são constituídos por mais de $30 \%$ de espécies iônicas com $\mathrm{m} / \mathrm{z}$ acima de 2000 sendo que o 1/LpA somente 16,6\% destas espécies.

Das espécies acima de $2000 \mathrm{~m} / \mathrm{z}, 36 \%$ são de espécies com $\mathrm{m} / \mathrm{z}$ acima de 2300 , enquanto que o lote $5 / \mathrm{LpA}$ tem $54,54 \%$ e o lote $7 / \mathrm{LpA}$ tem $25 \%$. Além disso, estes últimos lotes também apresentaram respectivamente, $12,23 \%$ e $14,53 \%$ de prováveis espécies triaciladas (com $\mathrm{m} / \mathrm{z}$ abaixo de 1200), não observadas nos lotes 1 e 4/LpA. Os lotes 2/LpA e 4/LpA são similares com 66,5\% e $61 \%$ de espécies predominantemente tetra e pentaaciladas e com $34,8 \%$ e $39,02 \%$ de espécies com 
$\mathrm{m} / \mathrm{z}$ acima de 2000 (figura 14). Os valores de fósforo total encontrados nos produtos foram para os lotes 1/LpA e 3/LpA, 646,2 e 526,9 nmoles e 958 nmoles para o FM.

(II)

(I)
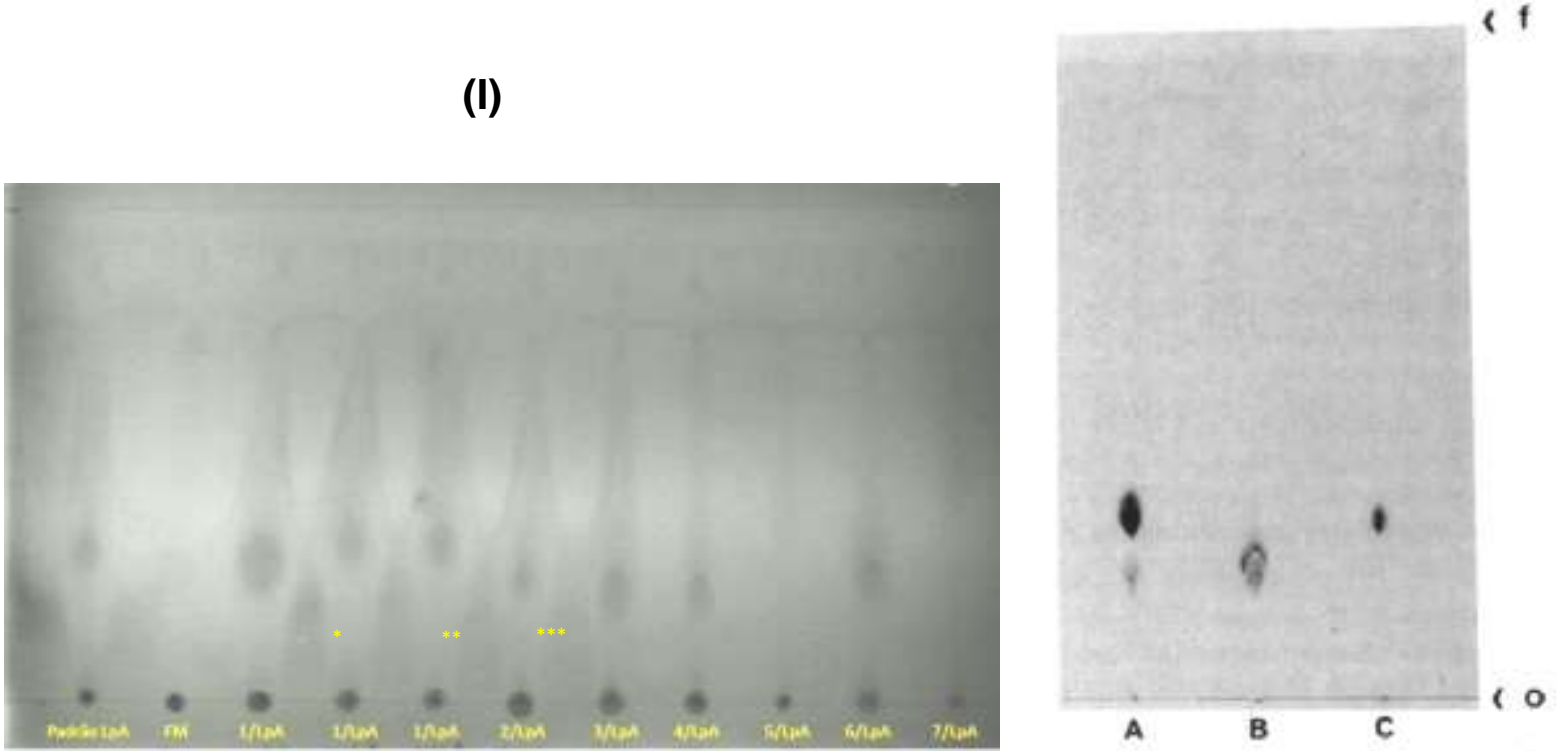

Figura 20: (I) Perfil dos lotes produzidos de BpLipídioA. Sistema de solventes: clorofórmio/metanol/água/trietilamina 3:1,5:0,25:0,1 (CAROFF et al., 1988, TIRSOAGA et al., 2007). Padrão LpA: Lote padrão de BpLipídioA com espécie iônica de $\mathrm{m} / \mathrm{z}$ 1586. FM: LPS extraído de Bordetella pertussis e os 7 lotes de LpA analisados, sendo o 1/LpA dividido em 3 sub-lotes: $1 / \mathrm{LpA}^{*}$ sub-lote $1 ; 2 / \mathrm{LpA}^{* *}$ sublote $2,1 / L p A^{* * *}$ sub-lote 3 , sendo esta divisão devido à liofilização de cada um dos lotes, que foi realizada separadamente. (II) TLC de Lipídio A isolado de B.pertussis; (A) Lipídio A isolado; (B) componente minoritário isolado; (C) componente majoritário isolado.

FONTE: Caroff et al. (1994). 


\subsection{Controle de processo}

Para assegurar que o produto final gerado pudesse ser testado em modelo animal, alguns fatores de controle de processo foram realizados, para garantir a total segurança do produto quando inoculado. Foram então realizados testes para verificação de esterilidade bacteriana e fúngica, $\mathrm{pH}$ e teor de amônia residual no produto final.

O teste de esterilidade bacteriana e fúngica foi realizado para comprovar a total ausência de contaminantes, que podem levar ao comprometimento do desempenho do produto, devido à quebra da estabilidade da formulação, alteração das características físicas e aparência e levar a inativação dos princípios ativos e excipientes da formulação. Mesmo que o preparo e a manipulação sejam realizados sob condições assépticas.

Para a realização do teste amostras dos produtos em questão foram incubadas em meio de tioglicolato fluido e meio de caseína de soja e acompanhadas durante um período de 14 dias. Ao final deste período de observação todas as amostras apresentaram-se estéreis, como demonstrado na tabela abaixo.

Tabela 12 - Teste de esterilidade de todos os lotes amostrados.

\begin{tabular}{|c|c|c|c|c|c|c|c|c|c|c|c|c|c|c|c|c|}
\hline Lotes & Meio de Cultura & \multicolumn{14}{|c|}{ Períndo de observação (dias) } & Resultado \\
\hline \multirow{2}{*}{ I/LpA } & Tinglicolato fluido* & e & e & e & 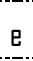 & e & $\mathrm{e}$ & e & $\mathrm{e}$ & e & $\mathrm{e}$ & e & $\mathrm{e}$ & $\mathrm{e}$ & e & \multirow{2}{*}{ Estéril } \\
\hline & Caseína de saja** & $\mathrm{e}$ & $\mathrm{e}$ & e & e & $\mathrm{e}$ & $\mathrm{e}$ & t... & e & $\mathrm{e}$ & $\mathrm{e}$ & e & $\mathrm{e}$ & $\mathrm{e}$ & e & \\
\hline \multirow{2}{*}{ 2/LpA } & Tinglicolato fluido & $\mathrm{e}$ & $\mathrm{e}$ & e & - & $\mathrm{e}$ & e & $\mathrm{e}$ & e & $\mathrm{e}$ & e & e & $\mathrm{e}$ & $\mathrm{e}$ & e & \multirow{2}{*}{ Estéril } \\
\hline & Caseína de saja & $\mathrm{e}$ & $\mathrm{e}$ & e & e & $\mathrm{e}$ & $\mathrm{e}$ & $\mathrm{e}$ & $\mathrm{e}$ & e. & $\mathrm{e}$ & $\mathrm{e}$ & $\mathrm{e}$ & $\mathrm{e}$ & e & \\
\hline \multirow{2}{*}{$3 / L p A$} & Tingliculato fluido & $\mathrm{e}$ & $\mathrm{e}$ & e & - & $\mathrm{e}$ & e & $\mathrm{e}$ & e & e & e & e & $\mathrm{e}$ & $\mathrm{e}$ & e & \multirow{2}{*}{ Estéril } \\
\hline & Caseína de saja & e & $\mathrm{e}$ & e & $\mathrm{e}$ & $\mathrm{e}$ & e & e & e & e. & $\mathrm{e}$ & e & $\mathrm{e}$ & e & e & \\
\hline \multirow{2}{*}{ 4/LpA } & Tinglicolato fluido & e & e & e & $\mathrm{e}$ & e & e & e & e & e & e & e & e & e & e & \multirow{2}{*}{ Estéril } \\
\hline & Caseína de saja & e & $\mathrm{e}$ & e & - & e & e & $\mathrm{e}$ & e & e & e & e & e & $\mathrm{e}$ & e & \\
\hline \multirow{2}{*}{$5 / L p A$} & Tinglicalata fluida & $\mathrm{e}$ & $\mathrm{e}$ & e & $\mathrm{e}$ & $\mathrm{e}$ & $\mathrm{e}$ & $\mathrm{e}$ & $\mathrm{e}$ & e & $\mathrm{e}$ & e & $\mathrm{e}$ & $\mathrm{e}$ & $\mathrm{e}$ & \multirow{2}{*}{ Estéril } \\
\hline & Caseína de saja & e & e & e & e & $\mathrm{e}$ & $\mathrm{e}$ & e & $\mathrm{e}$ & e. & $\mathrm{e}$ & e & e & $\mathrm{e}$ & e & \\
\hline \multirow{2}{*}{ 6/LpA } & Tinglicalata fluida & e & $\mathrm{e}$ & e & $\mathrm{e}$ & $\mathrm{e}$ & e & e & $\mathrm{e}$ & e. & $\mathrm{e}$ & e & $\mathrm{e}$ & $\mathrm{e}$ & e & \multirow{2}{*}{ Estéril } \\
\hline & Caseína de saja & e & $\mathrm{e}$ & e & $\mathrm{e}$ & e & e & $\mathrm{e}$ & e & e & $\mathrm{e}$ & e & e & $\mathrm{e}$ & e & \\
\hline \multirow{2}{*}{ 7/LpA } & Tingliculato fluido & e & e & e & $\mathrm{e}$ & $\mathrm{e}$ & $\mathrm{e}$ & e & e & e. & e & e & $\mathrm{e}$ & $\mathrm{e}$ & e. & \multirow[t]{2}{*}{ Estéril } \\
\hline & Caseína de saja & e & e & e & $\mathrm{e}$ & e & e & e & e & e & e & e & e & $\mathrm{e}$ & e & \\
\hline
\end{tabular}


No teste de teor de amônio residual nenhum dos lotes analisados apresentou quantidade superior a $5 \mathrm{ppm}$, valor este dentro dos limites estabelecidos para o nosso produto. Esta análise é requerida pois durante a produção do BpLipídioA a neutralização do pH (que encontra-se em torno de 3,4 na hidrólise com ácido acético) ocorre pela adição de hidróxido de amônio, resultando em acetato de amônio, que deve ser liberado durante o processo de liofilização, deixando o mínimo possível no produto final.

$\mathrm{O} \mathrm{pH}$ das amostras, neutralizado ao final do processo de hidrólise ácida, permaneceu em todos os lotes numa faixa entre 6,0 e 6,6. Este valor de pH é considerado ideal para que o produto seja introduzido em formulações vacinais e para que possam ser realizados os testes de toxicidade em modelo animal.

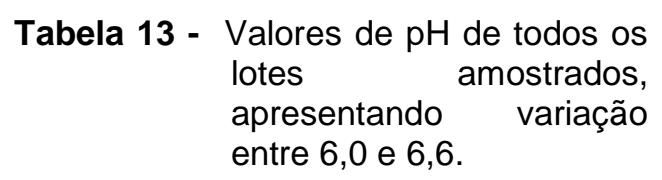

\begin{tabular}{|c|c|}
\hline Lote & $\mathrm{pH}$ \\
\hline 1/LpA & 6,6 \\
\hline 2/LpA & 6,4 \\
\hline 3/LpA & 6,4 \\
\hline 4/LpA & 6,6 \\
\hline 5/LpA & 6,1 \\
\hline G/LpA & 6,0 \\
\hline 7/LpA & 6.1 \\
\hline
\end{tabular}




\subsection{Avaliação da toxicidade in vivo}

Os testes de toxicidade em modelo animal são realizados para avaliar a existência de uma grande variedade de efeitos tóxicos. Estes testes muitas vezes representam o único meio pelo qual uma possível toxicidade em seres humanos gerada pelo produto em teste pode ser efetivamente prevista.

Para ser padronizado, um procedimento deve ter aceitação científica como o ensaio mais significativo para o efeito tóxico.

Os testes realizados para este produto foram o teste de pirogênio in vivo, toxicidade específica e inocuidade.

O teste da pirogênio in vivo é destinado a limitar a um nível aceitável os riscos de reação febril no paciente após a administração do produto em questão. O teste envolve a medição do aumento da temperatura dos coelhos, após a injeção intravenosa de uma formulação com uma dose que não deve exceder $10 \mathrm{~mL} / \mathrm{kg}$ administrado por via intravenosa, dentro de um prazo não superior a 10 minutos (THE UNITED STATES PHARMACOPEIA CONVENTION, 2007).

A presença de substâncias estranhas no organismo ativa o sistema imunológico, que reage produzindo pirógenos, estas moléculas são transportadas no sangue até o cérebro e alteram as funções metabólicas do hipotálamo, que em resposta promove o aumento da temperatura corporal, causando febre.

No teste de pirogênio in vivo realizado, o produto inoculado nos coelhos não ocasionou significativa variação de temperatura, sendo que a maior valor registrado ocorreu no lote 6/LpA, onde a somatória geral de todos os animais resultou em um aumento máximo de $0,4 \stackrel{\circ}{ } \mathrm{C}$. Houve uma tendência de aumento de temperatura nos animais, inoculados com os últimos lotes produzidos, apresentando então o maior pico de temperatura atingido entre os animais que estavam sendo submetidos ao teste (Figura 21).

Este aumento verificado não é superior ao limite estabelecido para a reprovação do produto, pois mesmo os últimos lotes produzidos não apresentam picos com intensidade acima de 2900 m/z, que são característicos de LOS, podendo assim explicar a variação da temperatura dos animais. 
Este produto é considerado apirogênico se nenhum coelho apresentar um aumento individual de temperatura de $0,5^{\circ} \mathrm{C}$ ou mais e se a soma de todos os aumentos individuais de temperatura não exceder $3,3^{\circ} \mathrm{C}$.

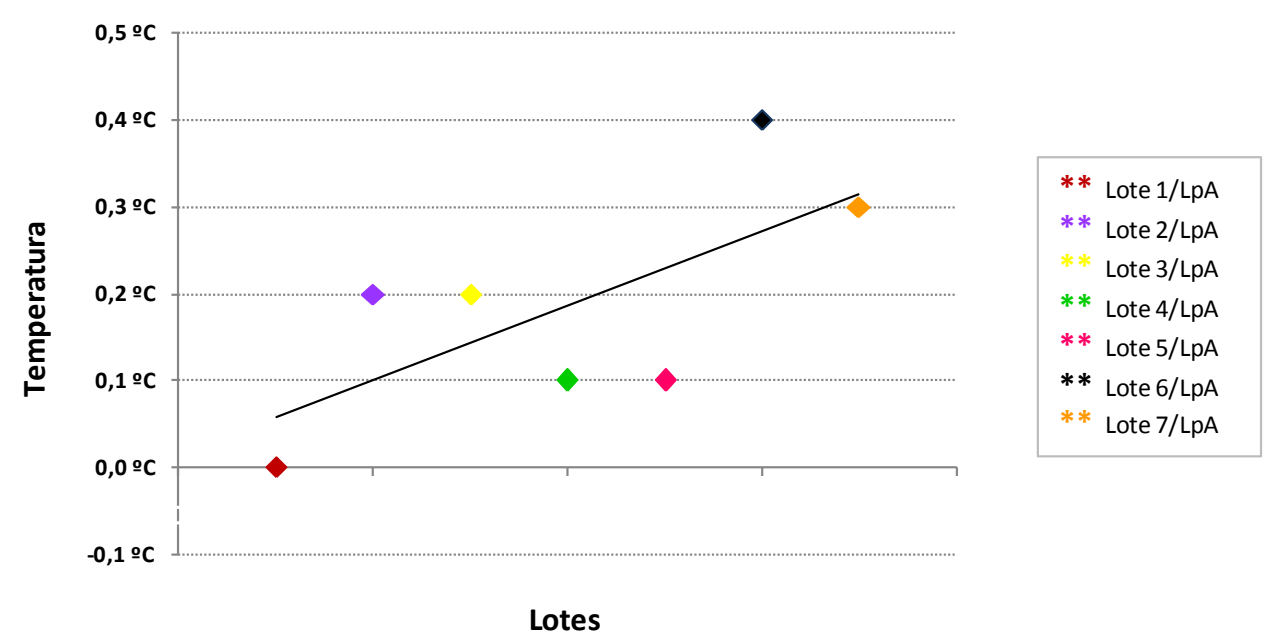

Figura 21: Variação de temperatura no teste de pirogênio in vivo dos lotes amostrados. A análise de tendência demonstrou que houve um aumento de temperatura nos animais inoculados com os últimos lotes produzidos: 6/LpA e 7/LpA, o que podemos relacionar com a análise espectrofotométrica sua abundância de fragmentos de LOS. 
O teste de toxicidade inespecífica ou inocuidade, é o teste mais importante a ser realizado num produto que será adicionado a uma formulação vacinal. As reações adversas tem efeito negativo sob uma formulação, devido a seus efeitos serem imediatamente evidenciados. Produtos derivados de Bordetella pertussis devem sempre ser testados quanto a uma possível toxicidade, sendo o teste de ganho de peso o mais empregado, onde os animais devem apresentar ganho de peso após 7 dias da inoculação do produto (METZ et al., 2002).

No teste de inocuidade realizado com os 7 lotes de produto, a variação de peso dos animais inoculados está expressa na tabela 14, sendo que todos os animais apresentaram ganho de peso, demonstrando a inocuidade dos lotes avaliados.

Não houve morte de nenhum animal durante os testes, nem alteração do estado de saúde geral dos mesmos, sendo que em alguns grupos o ganho de peso dos animais inoculados foi superior ao do grupo controle (Figura 22).

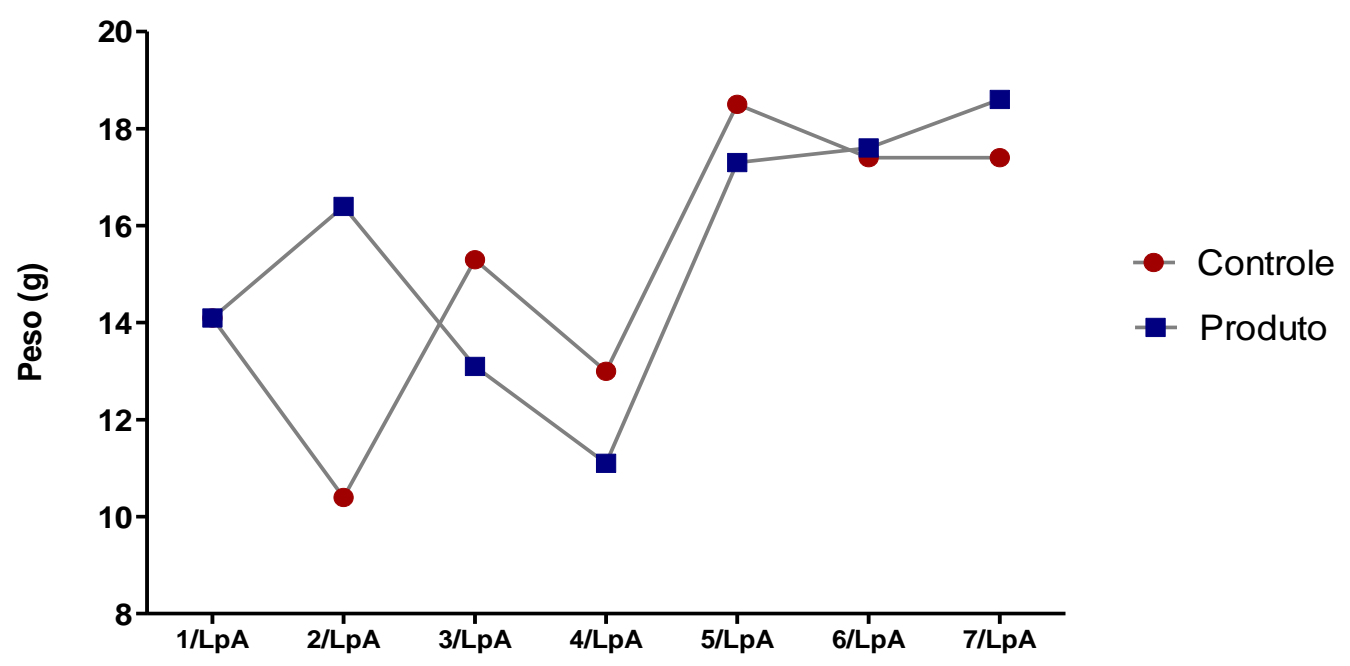

Figura 22: Variação de peso em (g) do grupo inoculado com relação ao grupo controle. 
Tabela 14 - Resultado da variação de peso dos camundongos inoculados com o produto e a solução controle durante o teste de inocuidade. * solução fisiológica $0,85 \%$.

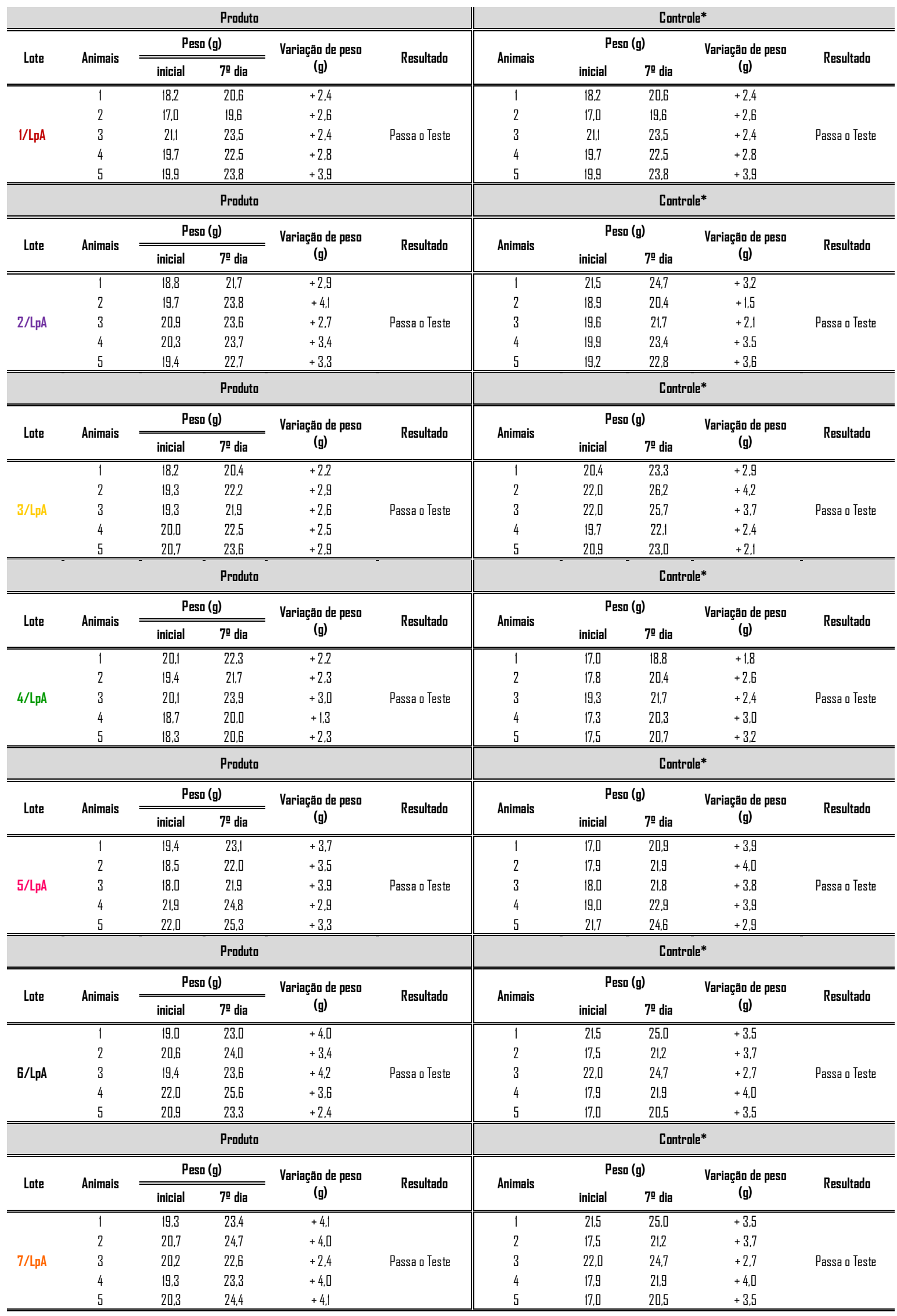


O teste de toxicidade específica estipulado desde 1991 pela Farmacopéia Européia se refere ao teste de ganho de peso ("weight gain test" MWG), que avalia as mudanças no peso corporal dos camundongos (CAMERON, 1976).

Neste teste o ganho de peso dos animais no $3^{\circ}$ dia, deve ser superior ao peso registrado no dia da inoculação, e o peso médio dos animais no $7^{\circ}$ dia deve ser $60 \%$ superior ao peso médio dos animais do grupo controle.

Este teste é baseado na observação de Pittman, que em 1952 encontrou uma correlação entre a toxicicidade dermonecrótica da toxina pertussis com o ganho de peso dos camundongos (HENDRIKSEN, 1988) e torna possível a verificação da total ausência da toxicidade causada por esta toxina (BARAFF et al., 1989). Neste estudo o ensaio foi realizado e é considerado essencial, devido ao produto em questão ser um derivado da Vacina Pertussis Celular.

As verificações de ganho de peso estão expressas na tabela 15 , demonstrando que todos os grupos tiveram um ganho de peso acima de $60 \%$ do total de ganho de peso do grupo controle. 
Tabela 15 - Variação de peso dos camundongos inoculados com o produto e com a solução controle durante o teste de toxicidade específica.

\begin{tabular}{|c|c|c|c|c|c|}
\hline Lote & & Produto & Controle & $\begin{array}{l}60 \text { \% da variaçăo do peso do } \\
\text { controle (g) }\end{array}$ & Resultado \\
\hline \multirow{4}{*}{ 1/LpA } & Pesa inicial (g) & 146,5 & 145,4 & \multirow{4}{*}{43,4} & \multirow{4}{*}{ Atóxico } \\
\hline & 30 dia & 168,2 & 184,0 & & \\
\hline & $70 \mathrm{dia}$ & 215,8 & 217,7 & & \\
\hline & Variaģẵ do pesa total da grupa (g) & 69,3 & 72,3 & & \\
\hline \multirow{4}{*}{ 2/LpA } & Pesa inicial (g) & 156,0 & 151,5 & \multirow{4}{*}{ 4प,8 } & \multirow{4}{*}{ Atóxico } \\
\hline & 30 dia & 197,6 & 187.4 & & \\
\hline & 70 dia & 226,0 & 219,5 & & \\
\hline & Variaçãa da pesa total da grupo (g) & 70,0 & 68.0 & & \\
\hline \multirow{4}{*}{ 3/LpA } & Pesa inicial (g) & 158,0 & 151,5 & \multirow{4}{*}{40,8} & \multirow{4}{*}{ Atáxico } \\
\hline & $3^{0}$ dia & 191,3 & 187,4 & & \\
\hline & 70 dia & 217,5 & 219,5 & & \\
\hline & Variação da peso total do grupo (g) & 59,5 & 68,0 & & \\
\hline \multirow{4}{*}{ 4/LpA } & Pesa inicial (g) & 299,5 & 296,5 & \multirow{4}{*}{84.8} & \multirow{4}{*}{ Atóxico } \\
\hline & $3^{\underline{0}} \mathrm{dia}$ & 361,5 & 381,2 & & \\
\hline & 70 dia & 408,3 & 437,8 & & \\
\hline & Variaģãa da pess total da grupo (g) & 108,8 & 141,3 & & \\
\hline \multirow{4}{*}{$5 / L p A$} & Pesa inicial (g) & 298,2 & 296,5 & \multirow{4}{*}{84,8} & \multirow{4}{*}{ Atóxico } \\
\hline & $3^{0} \mathrm{dia}$ & 386,0 & 381,2 & & \\
\hline & 70 dia & 450,3 & 437,8 & & \\
\hline & Variação da peso total do grupo (g) & 152,1 & 141,3 & & \\
\hline \multirow{4}{*}{ G/LpA } & Pesa inicial (g) & 299,7 & 296,5 & \multirow{4}{*}{84,8} & \multirow{4}{*}{ Atóxico } \\
\hline & $3^{0} \mathrm{dia}$ & 37,1 & 381,2 & & \\
\hline & 79 dia & 419,6 & 437.8 & & \\
\hline & Variação da pesa total do grupo (g) & $\| \square, 9$ & 141,3 & & \\
\hline \multirow{4}{*}{ 7/LpA } & Pesa inicial (g) & 299,7 & 296,5 & \multirow{4}{*}{84,8} & \multirow{4}{*}{ Atáxico } \\
\hline & $3^{0} \mathrm{dia}$ & 373,8 & 381,2 & & \\
\hline & 70 dia & 419,0 & 437,8 & & \\
\hline & Variação do peso total do grupo (g) & 119,3 & 141,3 & & \\
\hline
\end{tabular}

A concentração de produto inoculado nos animais foi 20 vezes superior a concentração estipulada para as formulações vacinais (QUINTILIO et al., 2009; MIYAKI et al., 2010). A variação de peso com relação ao grupo controle foi de $40,8 \%$ a $84,8 \%$ dentre os lotes analisados, conforme demonstrado nas figuras 23 , 24 e 25. 


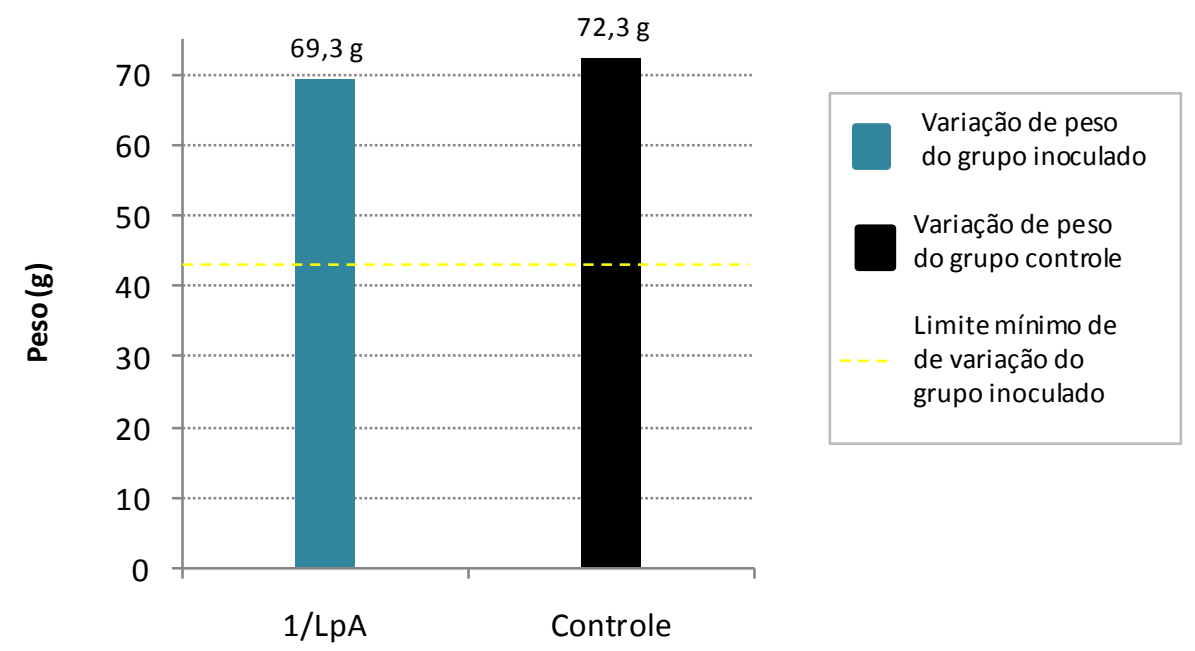

Figura 23: Porcentagem da variação de peso dos animais inoculados com o lote 1/LpA. O grupo de animais inoculados com o produto, apresentou ganho de peso de 69,3 g na somatória geral e o grupo controle $72,3 \mathrm{~g}$, ambos acima do limite mínimo de variação, que representa os $60 \%$ de ganho de peso do grupo controle.
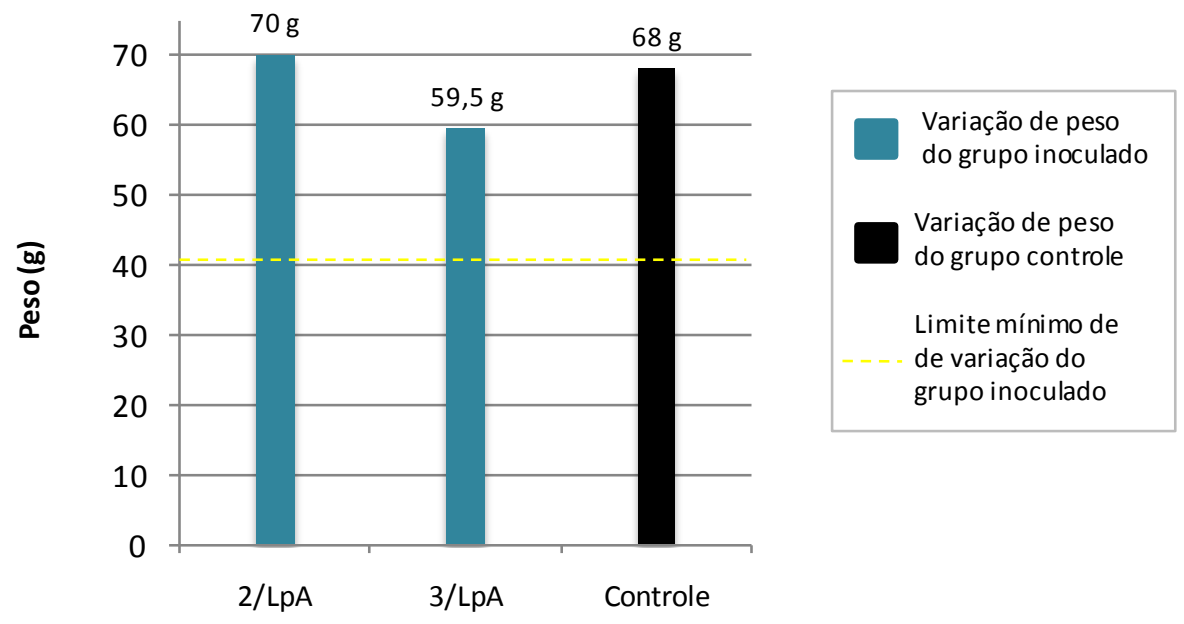

Figura 24: Porcentagem da variação de peso dos animais inoculados com os lotes $2 / \mathrm{LpA}$ e $3 / \mathrm{LpA}$. Os grupos de animais inoculados com o produto apresentaram ganho de peso de $70,0 \mathrm{~g}$ e $59,5 \mathrm{~g}$ sendo que o grupo controle apresentou ganho de peso de $68,0 \mathrm{~g}$, ambos lotes tiveram valores acima do limite mínimo de variação, que representa os $60 \%$ de ganho de peso do grupo controle. 


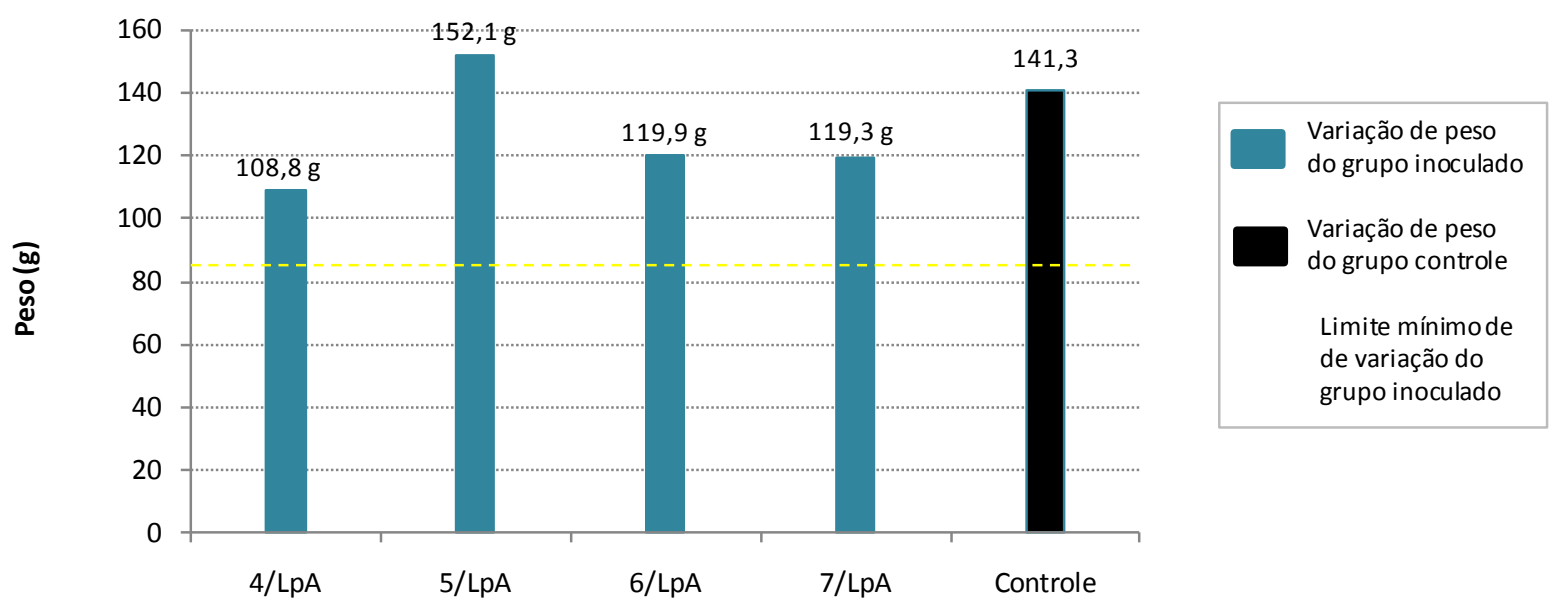

Figura 25: Porcentagem da variação de peso dos animais inoculados com os lotes 4/LpA, 5/LpA, 6/LpA e 7/LpA. Os grupos de animais inoculados com o produto apresentaram ganho de peso de $108,8 \mathrm{~g}, 152,1 \mathrm{~g}, 119,9 \mathrm{~g}, 119,3 \mathrm{~g}$, sendo que o grupo controle apresentou ganho de peso de $141,3 \mathrm{~g}$, todos os lotes apresentaram valores acima do limite mínimo de variação, que representa os $60 \%$ de ganho de peso do grupo controle.

Todos os testes empregados para verificação de uma possível toxicidade causada pelo produto apresentaram resultados satisfatórios demonstrando que o produto não causa reações adversas como febre e lesões dermonecróticas, confirmando o que foi descrito por Gao et al. em 2006, onde o LPS de Bordetella pertussis apresenta total perda de sua atividade endotóxica quando submetido a aquecimento a $100{ }^{\circ} \mathrm{C}$ e por consequência o Lipídio A que é parte deste LPS, também demonstrou-se completamente atóxico. 


\subsection{Atividade imunogênica}

Para verificação da possível atividade adjuvante do BpLipídioA, este produto foi formulado com o antígeno de hepatite $B$ recombinante, com ou sem hidróxido de alumínio e com a metade da concentração de antígeno utilizada na vacina tradicional.

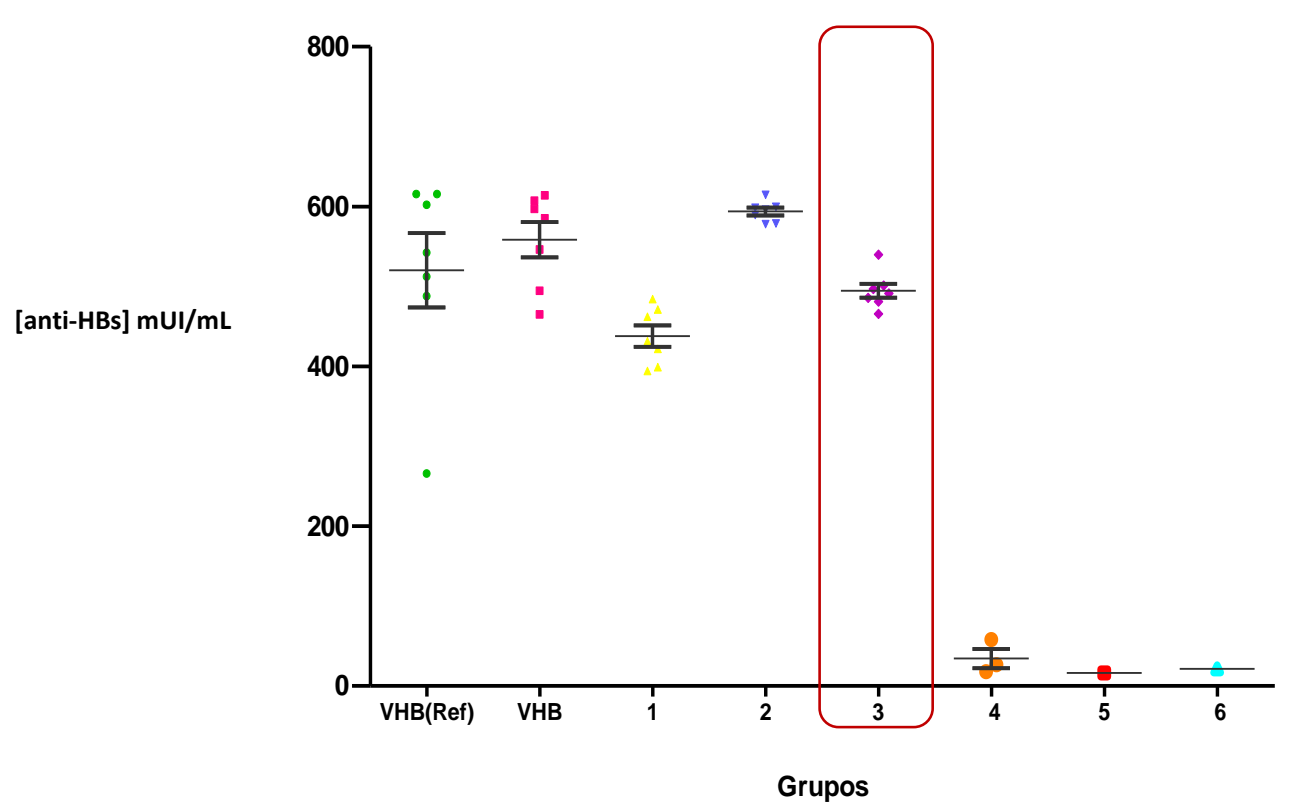

Figura 26: Título de anticorpo anti-HBs obtido por imunoensaio do tipo ELISA após 30 dias da inoculação dos animais com as diferentes formulações vacinais. $\square$ VHB Ref - Vacina recombinante contra Hepatite B (Referência); $\square$ VHB - Lote de Vacina recombinante contra Hepatite B; $\square 1$ - rHBsAg 0,625 $\mu \mathrm{g} /$ dose; $\square 2$ - rHBsAg 0,625 $\mu \mathrm{g} /$ dose $+\mathrm{Al}(\mathrm{OH})_{3}$; $\square 3-\mathrm{rHBsAg} 0,312 \mu \mathrm{g} /$ dose $+\mathrm{Al}(\mathrm{OH})_{3}+$ BpLipídioA $10 \mu \mathrm{g} /$ dose; $\square 4-\mathrm{rHBsAg} 0,312$ $\mu \mathrm{g} /$ dose + BpLipídioA $10 \mu \mathrm{g} /$ dose; $\square 5$ - BpLipídioA $10 \mu \mathrm{g} /$ dose; $\square 6$ - controle. Análise realizada pelo programa GraphPad Prism versão 5.04 para Windows. 
Tabela 16 - Análise estatística do título de anticorpos anti-HBsAg obtida pelo programa 1way ANOVA.

\begin{tabular}{|c|c|c|c|c|}
\hline Grupos & $\begin{array}{c}\text { Média } \\
\text { (Títula de anti- } \\
\text { HBs) } \\
\text { mlll/mL }\end{array}$ & $\begin{array}{l}\text { Desvio padrão } \\
\text { (SD) }\end{array}$ & Títula máxima & $\begin{array}{l}\text { Título } \\
\text { Mínimo }\end{array}$ \\
\hline Vacina Referência & 173,4 & 41,08 & 205,2 & 88,68 \\
\hline $\begin{array}{l}\text { Lote de Vacina de Hepatite } \\
\text { Recombinante }\end{array}$ & 186,2 & 19,58 & 204,7 & 155,0 \\
\hline Grupo I & 146,0 & 11,82 & 161,4 & 131,5 \\
\hline Gгиро 2 & 197,9 & 4,26 & 204,9 & 192,8 \\
\hline Gгиро 3 & 164,9 & 7,69 & 180,0 & 155,3 \\
\hline Бгиро 4 & 111,44 & $7, \mathrm{7,DI}$ & 19,36 & 6.02 \\
\hline Бгира 5 & 5,51 & --- & 5,51 & 5,51 \\
\hline Gгиро 6 & 7,12 & --- & 7,12 & 7,12 \\
\hline
\end{tabular}

O título médio obtido no grupo 3 de $164,9 \mathrm{mUl} / \mathrm{mL}$ é o mais importante dado do estudo realizado, pois demonstra que com a metade da concentração de antígeno de hepatite $B$ recombinante utilizada no ensaio do lote vacinal é possível se obter um título de anti-HBsAg próximo ao da vacina tradicional de 186,2 $\mathrm{mUl} / \mathrm{mL}$ provavelmente devido a adição de $20 \mu \mathrm{g} / \mathrm{mL}$ do adjuvante BpLipídioA.

Este dado possibilita sugerir que a utilização de um segundo adjuvante na formulação da vacina de hepatite, reduziria a dose de antígeno necessária, aumentando assim a capacidade de produção desta vacina produzida no Instituto Butantan, e também seria possível a redução do hidróxido de alumínio.

Alguns estudos apresentaram dados de vacinas de hepatite $B$ formuladas com o monofosforil Lipídio A (Glaxo-Smith-Kline) e testadas em pacientes hepatotransplantados que obtiveram resultados significativos da atividade adjuvante deste lipídio A (DI PAOLO et al., 2010). 


\subsection{Emulsões}

As emulsões preparadas conforme descrito no capítulo 3 foram submetidas primeiramente ao teste de esterilidade bacteriana e fúngica, que demonstrou que as emulsões formuladas estavam estéreis, podendo então serem submetidas aos testes de $\mathrm{pH}$ e toxicidade e posteriormente aos testes específicos para avaliar o tamanho e dispersão das partículas destas emulsões (Tabela 17).

Tabela 17 - Testes de controle de processo e toxicidade realizados nas emulsões formuladas com as concentrações de $20 \mu \mathrm{g} / \mathrm{mL}, 100 \mu \mathrm{g} / \mathrm{mL}$ e $400 \mu \mathrm{g} / \mathrm{mL}$.

\begin{tabular}{|c|c|c|c|c|c|}
\hline & Esterilidade & $\mathrm{pH}$ & Inocuidade* & Pirogênio in vivo & LAL \\
\hline Emulsãa & estéril & 7,3 & Atóxico & Apirogênico & $<50, \mathrm{QU} \mathrm{UE} / \mathrm{mL}$ \\
\hline $\begin{array}{l}\text { Emulsão com BpLipídioA } \\
(2 \square \mu g / m L)\end{array}$ & estéril & 7,3 & Atóxica & Apiragênico & $65,45 \mathrm{UE} / \mathrm{mL}$ \\
\hline $\begin{array}{l}\text { Emulsão com BplipídiaA } \\
(\text { (I0口 } \mu g / m L)\end{array}$ & estéril & 7,3 & Atóxica & Apirogênico & $<50, \mathrm{QU} \mathrm{EU} / \mathrm{mL}$ \\
\hline $\begin{array}{l}\text { Emulsãa com BpLipídioA } \\
(400 \mu \mathrm{g} / \mathrm{mL})\end{array}$ & estéril & 7,1 & Atóxica & Apiragênico & $<50, \mathrm{QU} \mathrm{EU} / \mathrm{mL}$ \\
\hline
\end{tabular}

*Taxicidade inespecífica

Tabela 18 - Resultado do ganho de peso dos animais durante o teste de inocuidade. Os animais do grupo controle, inoculados com solução fisiológica apresentaram ganho de peso de 16,4 g.

\begin{tabular}{|c|c|c|c|c|c|c|c|c|c|c|c|}
\hline \multirow{2}{*}{ Lote } & \multirow{2}{*}{ Animais } & \multicolumn{2}{|c|}{ Pesa (g) } & \multirow{2}{*}{$\begin{array}{l}\text { Variaçãa de pesa } \\
\text { (g) }\end{array}$} & \multirow{2}{*}{ Resultada } & \multirow{2}{*}{ Animais } & \multicolumn{2}{|c|}{ Pesa (g) } & \multirow{2}{*}{$\begin{array}{l}\text { Variaçãa de } \\
\text { peso (g) }\end{array}$} & \multirow{2}{*}{ Resultada } & \multirow{2}{*}{ Lote } \\
\hline & & inicial & $70 \mathrm{dia}$ & & & & inicial & $70 \mathrm{dia}$ & & & \\
\hline \multirow{5}{*}{$\begin{array}{l}\text { Emulsão } \\
20 \text { g/mL }\end{array}$} & 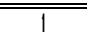 & 18,2 & 20,3 & $+2,1$ & \multirow{5}{*}{$+\| 1,0 \mathrm{~g}$} & 1 & 20,2 & "23,0 & $+2,8$ & \multirow{5}{*}{$+12,9 \mathrm{~g}$} & \multirow{5}{*}{$\begin{array}{l}\text { Emulsãa } \\
400 \mu \mathrm{g} / \mathrm{mL}\end{array}$} \\
\hline & 2 & 2Q,2 & 22,8 & $+2,6$ & & 2 & 19,7 & 22,8 & $+3,1$ & & \\
\hline & 3 & 21,5 & 23,8 & $+2,3$ & & 3 & 21,5 & 23,7 & $+2,2$ & & \\
\hline & 4 & 20,2 & 22,0 & $+1,8$ & & 4 & 20,0 & 22,5 & $+2,5$ & & \\
\hline & 5 & 19,6 & 21,8 & $+2,2$ & & 5 & 19,5 & 21,8 & $+2,3$ & & \\
\hline \multirow{2}{*}{ Lote } & \multirow{2}{*}{ Animais } & \multicolumn{2}{|c|}{ Pesa (g) } & \multirow{2}{*}{$\begin{array}{l}\text { Variaçãa de pesa } \\
\text { (g) }\end{array}$} & \multirow{2}{*}{ Resultado } & \multirow{2}{*}{ Animais } & \multicolumn{2}{|c|}{ Pesa (g) } & Variaçãa de & \multirow{2}{*}{ Resultado } & \multirow{2}{*}{ Lote } \\
\hline & & inicial & 70 dia & & & & inicial & 70 dia & pess (g) & & \\
\hline \multirow{5}{*}{$\begin{array}{l}\text { Emulsão } \\
\text { |00 } \mu \mathrm{g} / \mathrm{mL}\end{array}$} & 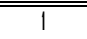 & 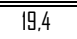 & 21,8 & +2.4 & \multirow{5}{*}{$+12,8 \mathrm{~g}$} & 1 & 201,7 & 23,7 & $\begin{array}{c}+2,0 \\
\end{array}$ & \multirow{5}{*}{$+10,9 \mathrm{~g}$} & \multirow{5}{*}{ Emulsão } \\
\hline & 2 & 19,3 & 21,5 & $+2,2$ & & 2 & 2Q,8 & 22.8 & $+2,0$ & & \\
\hline & 3 & 2Q,0 & 23,2 & $+3,2$ & & 3 & 21,2 & 23,4 & $+2,2$ & & \\
\hline & 4 & 17,5 & 19,8 & $+2,3$ & & 4 & 21,5 & 23,8 & $+2,3$ & & \\
\hline & 5 & 18.7 & 21,4 & +2.7 & & 5 & 21,0 & 23,4 & $+2,4$ & & \\
\hline
\end{tabular}


Após a obtenção dos resultados dos testes de controle de processo e de toxicidade, as emulsões foram mantidas em uma temperatura de 2 a $8^{\circ} \mathrm{C}$ por 6 meses, onde durante este período foram submetidas à análise do tamanho e distribuição do tamanho de suas partículas para verificar a estabilidade das amostras e se houve separação de fases.

O tamanho da partícula foi determinado no tempo zero e durante o período de estabilidade através da dispersão dinâmica da luz (DLS) utilizando equipamento Malvern Zetasizer Nano-S. O tamanho médio da partícula da emulsão é um indicador da estabilidade. O tamanho médio da partícula é visto como Z-avg, que é a média da intensidade da dispersão do tamanho da partícula obtida da DLS, para esta análise as emulsões foram diluídas 1:1000 no tampão da fase aquosa.

A estabilidade de uma emulsão refere-se à habilidade de uma emulsão de permanecer inalterada durante um determinado período de tempo. Normalmente, a estabilidade é aferida por meio de exposição da emulsão à temperaturas elevadas ou choques térmicos. Porém, outros mecanismos físicos interagem com as emulsões e podem levar esta emulsão à quebra, sedimentação ou floculação.

Em geral as emulsões são classificadas como instáveis se elas exibirem mais que $50 \%$ de crescimento de partículas durante 3 meses ou mais de $20 \%$ de crescimento das partículas na primeira semana. São metaestáveis se exibirem de 11 a $50 \%$ de crescimento do tamanho das partículas e estáveis se o tamanho da partícula crescer $10 \%$ ou menos após 3 meses de sua produção sob refrigeração (FOX et al., 2008).

Tabela 19 - Análise da estabilidade das emulsões durante 6 meses de armazenamento em temperatura de 2 a $8^{\circ} \mathrm{C}$.

\begin{tabular}{|c|c|c|c|c|c|c|}
\hline \multirow{3}{*}{ Emulsũes } & \multicolumn{6}{|c|}{2 a ${ }^{\circ}$} \\
\hline & \multicolumn{2}{|c|}{ Z-Average/Pdl } & \multicolumn{2}{|c|}{$\begin{array}{l}\text { Tamanho da partícula } \\
\text { (d.nm) }\end{array}$} & \multicolumn{2}{|c|}{ Intensidade (\%) } \\
\hline & 1 mês & 6 meses & 1 mês & 6 meses & 1 mês & 6 meses \\
\hline Emulsão & 174,6/0,039 & 175,8/0,0126 & $141,8-255,0$ & 122,4 - 255,0 & 82,7 & 79,5 \\
\hline $\begin{array}{l}\text { Emulsãu com BpLipídioA } \\
(20 \mu \mathrm{g} / \mathrm{mL})\end{array}$ & 127,8/0,122 & 133,6/0,096 & 91,28 - 190,1 & $105,7-190,1$ & 73,8 & 69,1 \\
\hline $\begin{array}{l}\text { Emulsão com BpLipídioA } \\
(\text { (ID马 } \mu \mathrm{g} / \mathrm{mL})\end{array}$ & $154, \mid / 0,095$ & 152,8/0,088 & 12Z,4-Z2Q,2 & 12Z,4-220,2 & 74,2 & 74.1 \\
\hline $\begin{array}{l}\text { Emulsãa com BpLipídioA } \\
\text { (400 } \mu \mathrm{g} / \mathrm{mL})\end{array}$ & 158,5/0,079 & 174,5/0,204 & IZZ,4-Z2Z,Z & 12Z,4-220,2 & 75,1 & 81,9 \\
\hline
\end{tabular}


Os resultados das emulsões formuladas durante 6 meses de estocagem em temperatura de 2 a $8{ }^{\circ} \mathrm{C}$ atestam sua estabilidade. As emulsões foram visualmente inspecionadas para observação de separação de fases e agregação antes da análise da dispersão da luz. Não houve separação de fase ou observação de agregação das partículas, que permaneceram com um bom índice de polidispersão (Tabela 19).

(l)

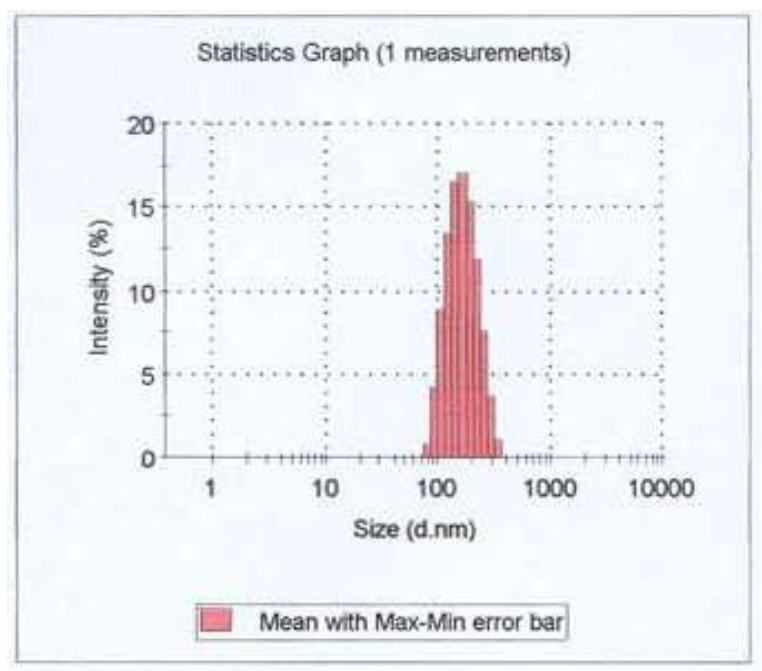

(II)

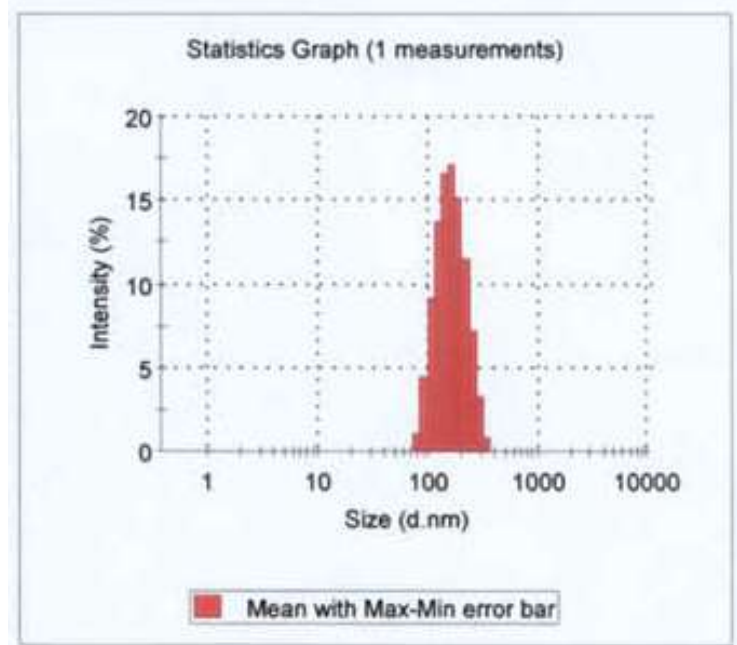

Figura 27: Gráfico de distribuição das partículas com relação ao seu tamanho e intensidade, (I) primeira análise após o preparo da emulsão e (II) segunda análise após 6 meses de preparo da emulsão de $100 \mu \mathrm{g} / \mathrm{mL}$, demonstrando que não houve alteração na intensidade ou tamanho das partículas.

(l)

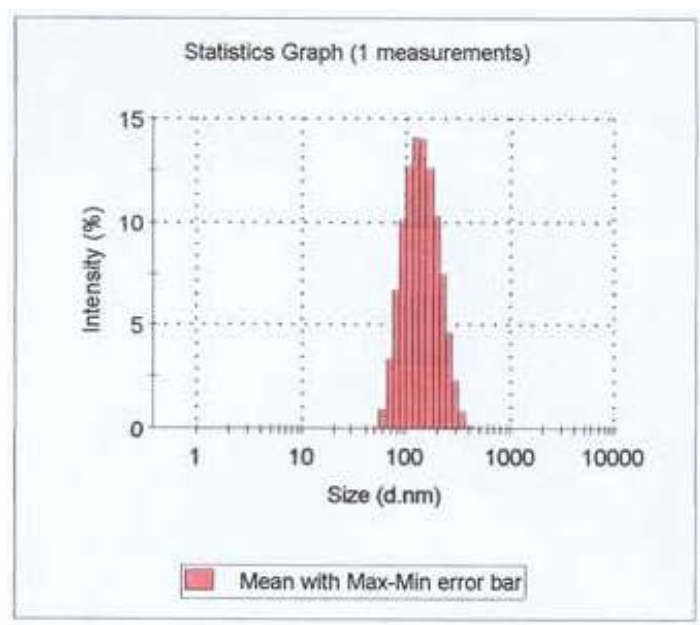

(II)

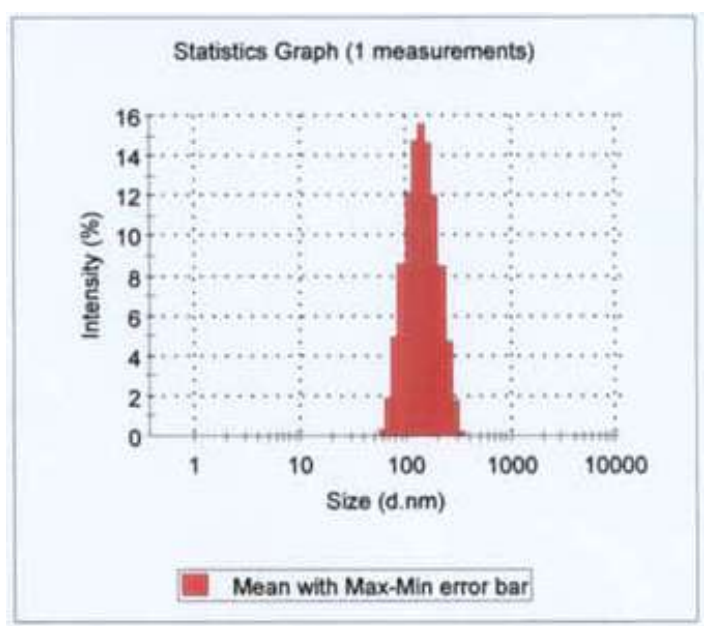

Figura 28: Gráfico de distribuição das partículas com relação ao seu tamanho e intensidade, (I) primeira análise após o preparo da emulsão e (II) segunda análise após 6 meses de preparo da emulsão de $20 \mu \mathrm{g} / \mathrm{mL}$, demonstrando que houve uma variação de 91,28 nm para $105,7 \mathrm{~nm}$, que não foi considerada significativa, pois ainda é metaestável, apresentando um crescimento em torno de $15 \%$ no tamanho da partícula. 
Estas emulsões podem ser classificadas como nanoemulsões, pois apresentam partículas da fase dispersa de tamanho menor que $200 \mathrm{~nm}$, característica esta considerada ideal para uso farmacêutico, sendo possível sua esterilização por filtro $0,22 \mu \mathrm{m}$. 


\section{CAPÍTULO $v$}

\section{CONCLUSÃO}

O produto BpLipídioA é heterogêneo, e o padrão de fragmentação apresentado está também relacionado ao processo de hidrólise ácida, com espécies iônicas de relação $\mathrm{m} / \mathrm{z}$ de acordo com os dados obtidos na literatura (CAROFF et al., 1994, 2000; CAROFF; KARIBIAN, 2003; GEURTSEN, 2007; TIRSOAGA et al., 2007; MARR et al., 2008; EL HAMID et al., 2009, GEURTSEN et al., 2009, MARR et al., 2010).

A heterogeneidade pode ser melhor controlada pela definição e robustez do método de produção. O percentual de compostos acima de $2000 \mathrm{~m} / \mathrm{z}$ precisa ser definido e preferencialmente abaixo de $10 \%$.

Os testes de toxicidade demonstraram que o produto apresentou-se atóxico nas concentrações estudadas, mesmo nas concentrações mais elevadas de $200 \mu \mathrm{g} / \mathrm{mL}$, não ocasionando nenhum tipo de lesão dermonecrótica, febre ou morte dos animais, podendo então ser submetido à ensaios clínicos de formulações vacinais em estudo.

As metodologias analíticas realizadas permitiram caracterizar tanto a matériaprima quanto o produto final obtido, que apresentam variações que estão diretamente relacionadas ao processo produtivo. A dosagem de fósforo permite no produto final (BpLipídioA) constatar sua defosforilação. A TLC também pode caracterizar o produto sob este ângulo.

O ensaio para verificação de atividade adjuvante do BpLipídioA demonstrou que este produto não é imunogênico e a formulação deste com a Vacina recombinante contra Hepatite $B$, apresentou um título de anti-HBsAg similar ao da vacina tradicional, utilizando somente a metade da concentração de antígeno vacinal, ou seja, o emprego do adjuvante BpLipídioA, de baixo custo, por ser um 
sub-produto da Vacina Pertussis, aumentaria a capacidade de produção da Vacina recombinante contra Hepatite $B$.

Estes resultados de capacidade adjuvante nos levaram a testar o adjuvante em diferentes concentrações em uma emulsão óleo em água. Estas emulsões formuladas passaram em todos os testes de controle de processo e toxicidade, apresentando-se estáveis durante um período de seis meses, o que nos leva a uma perspectiva futura de testar estas formulações com diferentes antígenos vacinais.

Em 2010 foi realizado um estudo de atividade adjuvante do MPLA em emulsão e suspensão, para a vacina contra influenza H5N1. Este adjuvante é um outro derivado de LPS de Bordetella pertussis, onde o título de anticorpos das formulações de MPLA em emulsão foi superior ao das formulações com o MPLA em suspensão (MIYAKI et al., 2010). 


\section{REFERÊNCIAS*}

AVANTI POLAR LIPIDS. Lipid A Detoxified (Salmonella minnesota R595). Bioactive Lipids. Alabaster, USA \& Canadá, 2011. Disponível em: $\mathrm{http}: / \mathrm{www}$.avantilipids.com/index. php?option=com_content\&view=article\&id=405\&lte $\mathrm{mid}=318 \&$ catnumber $=699200$. Acesso em: $10 \mathrm{fev} . \overline{2009}$.

BALDRICK, P.; RICHARDSON, D.; ELLIOTT, G.; WHEELER, A. W. Safety Evaluation of Monophosphoryl Lipid A (MPL): An Immunostimulatory Adjuvant. Regulatory Toxicology and Pharmacology, v. 35, p. 398-413, 2002.

BALDRIDGE, J. R.; CRANE, T. Monophosphoryl Lipid A (MPL) Formulations for the Next Generation of Vaccines. Methods, v. 19, p. 103-107, 1999.

BARAFF, L. J.; LEAKE, R. D.; BURSTYN, D. G.; PAYNE, T.; CODY, C. L.; MANCLARK, C. R.; GEME, J. W. Analyses of adverse reactions to diphtheria and tetanus toxioids and pertussis vaccine by vaccine lot, endotoxin content, pertussis vaccine potency and percentage of mouse weight gain. Pediatrics Infect. Dis. J., v. 8, p. 502-507, 1989.

BARTELING, S. J.; VREESWIJK, J. Developments in foot-and-mouth disease vaccines. Vaccine, v. 9, p. 75-88, 1991.

BIANCHI, M. E. DAMPS, PAMPs and alarmins: all we need to know about danger. Journal of Leukocyte Biology, v. 81, n. 1, p, 1-5, 2007.

BRAGA, W. S. M.; BRASIL, L. M.; SOUZA, R. A. B.; MELO, M. S.; ROSAS, M. D. G.; CASTILHO, M. C.; FONSECA, J. C. F. Prevalence of Hepatitis B Virus (HBV) and Hepatitis D Virus (HDV) Infections. Epidemiologia e Serviços de Saúde, v. 13, p. 35-46, 2004.

CAMERON, J. Pertussis vaccine: mouse-weight-gain (toxicity) test. Dev. Biol. Stand., v. 34, p. 213-215, 1976.

CAROFF, M.; BRISSON, J.; MARTIN, A.; KARIBIAN, D. Structure of the Bordetella pertussis 1414 endotoxin. FEBS Lett., v. 477, p. 8-14, 2000.

CAROFF, M.; CAVAILLON, J. M.; FITTING, C.; HAEFFNER-CAVAILLON, N. Inability of pyrogenic, purified Bordetella pertussis lipid $A$ to induce interleukin-1 release by human monocytes. Infect. Immun., v. 54, p. 465-471, 1986. 
CAROFF, M.; DEPRUN, C.; RICHARDS, J. C.; KARIBIAN, D. Structural characterization of the lipid A of Bordetella pertussis 1414 endotoxin. J. Bacteriol., v. 176, p. 5156-5159, 1994.

CAROFF, M.; KARIBIAN, D.; CAVAILLON, J. M.; HAEFFNER-CAVAILLON, N. Structural and functional analyses of bacterial lipopolysaccharides. Microbes Infect., v. 4, p. 915-926, 2002.

CAROFF, M.; KARIBIAN, D. Structure of bacterial lipopolysaccharides. Carbohydrate Research, v. 338, p. 2431-2447, 2003.

CAROFF, M.; TACKEN, A.; SZABÓ, L. Detergent-accelerated hydrolysis of bacterial endotoxins and determination of the anomeric configuration of the glycosyl phosphate present in the "isolated lipid A" fragment of the Bordetella pertussis endotoxin. Carbohydr Res., v. 175, p. 273-282, 1988.

CLEMENTS, C.; GRIFFITHS, E. The global impact of vaccines containing aluminium adjuvants. Vaccine, v. 20, n. 3, p. 24-33, 2002.

COMMITTEE FOR PROPRIETARY MEDICINAL PRODUCTS - CPMP. Note for Guidance on the Pre-clinical Pharmaceutical and Toxicological Testing of Vaccines, (CPMP/SWP/465.95), 1997. Disponível em: < http://www.emea.eu.int>. Acesso em: 22 nov. 2010.

COSTA, A. A.; INENAMI, M.; JUAREZ, E.; LLACEN, P. D.; RAW, I. Preliminary Report of the Use of a Recombinant Yeast derived Hepatitis B Vaccine Manufactured by Instituto Butantan. Rev. Inst. Med. Trop. São Paulo, v. 39, n.1, p. 39-42, 1997.

COX, J. C.; COULTER, A. R. Adjuvants - a classification and review of their modes of action. Vaccine, v. 15, p. 248-256, 1997.

DE GREGORIO, E.; TRITTO, E.; RAPPUOLI, R. Alum adjuvanticity: unraveling a century old mystery. European Journal of Immunology, v. 38, p. 2068-2071, 2008.

DI PAOLO, D.; LENCI, I.; CEROCCHI, C.; MONACO, A.; LOTTI, L; TISONE, G.; ANGELICO, M. One-year vaccination against hepatitis $B$ virus with a MPL-vaccine in liver transplant patients for HBV-related cirrhosis. Transplant International, v. 23, p. 1105-1112, 2010. 
DOUGAN, G.; HORMAECHE, C. How bacteria and their products provide clues to vaccine and adjuvant development. Vaccine, n. 24, p. 13-19, 2006.

EDELMAN, R.; TACKET, C. O. Adjuvants. International Review in Immunology, v. 7, p. 51-66, 1990.

EL HAMIDI, A.; NOVIKOV, A.; KARIBIAN, D.; PERRY, M.; CAROFF, M. Structural characterization of Bordetella parapertussis lipid A. Journal of Lipid Research, v. 50, p. 854-859, 2009.

EL HAMIDI, A.; TIRSOAGA, A.; NOVIKOV, A.; HUSSEIN, A; CAROFF, M. Microextraction of bacterial lipid $A$ : easy and rapid method for mass spectrometric characterization. Journal of Lipid Research, v. 46, p. 1173-1178, 2005.

ERRIDGE, C.; BENNETT-GUERRERO, E.; POXTON, I. R. Structure and function of lipopolysaccharides. Microbes Infec., v. 4, p. 837-851, 2002.

ESSER, M. T.; MARCHESE, R. D.; KIERSTEAD, L. S. TUSSEY, L. G.; WANG, F. CHIRMULE, N.; WASHABAUGH, M. W. Memory T Cells Vaccines. Vaccine, v. 21, p. $419-430,2003$.

EUROPEAN PATENT. P. M. Momin; M. J. Garcon. Vaccines comprising oil/water emulsion with tocopherol and squalene. Patente $n^{\circ}$. EPO868918 B1 Application number: 98201308.8, 28 abr. 2004.

FOOD AND DRUG ADMINISTRATION. Guideline on validation of the Limulus Amebocyte Lysate test as an end-product endotoxin test for human and animal parenteral drugs, biological products, and medical devices. Center for Drug Evaluation and Research, Rockville, USA. December, 1987.

FOX, C. B.; DUTILL, T. S.; CHESKO, J.; REED, S. G.; VEDVICK, T. S. Monitoring the effects of component structure and source on formulation stability and adjuvant activity of oil-in-water emulsions. Colloids and Surfaces B: Biointerfaces, v. 65, p. 98-105, 2008.

FREUND, J. The mode of action of immunologic adjuvants. Adv. Tuberc. Res., v. 7, p. 130-148, 1956. 
GALANOS, C.; LEHMANN, V.; LUDERITZ, O.; RIETSCHEL, E.; WESTPHAL, O.; BRADE, H.; BRADE, L.; FREUDENBERG, M. A.; HANSEN-HAGGE, T.; LUDERITZ, T.; McKENZIE, G.; SCHADE, U.; STRITTMATTER, W.; TANAMOTO, K. I.; ZAHRINGER, U.; IMOTO, M.; YOSHIMURA, H. Endotoxic properties of chemically synthesized lipid A part structures. Comparison of synthetic lipid A precursor and synthetic analogues with biosynthetic lipid A precursor and free lipid A. Eur. J. Biochem., v. 140, p. 221-227, 1984.

GAO, B.; WANG, Y.; TSAN, M. F. The heat sensitivity of cytokine-inducing effect of Lipopolysaccharide. Journal of Leukocyte Biology, v. 80, p. 259-266, 2006.

GARÇON, N.; CHOMEZ, P.; VAN MECHELEN, M. Adjuvant Systems in vaccines: concepts, achievements and perspectives. Expert Rev. Vaccines, v. 6, p. 723-739, 2007.

GEURTSEN, J. Improving pertussis vaccines by lipopolysaccharide engineering. 2007. 303 p. Ph. D Thesis (Biochemistry) - University of Utrecht, Utrecht, 2007.

GEURTSEN, J.; DZIECIATKOWSKA, M.; STEEGHS, L.; HAMSTRA, H. J.; BOLEIJ, J.; BROEN, K.; AKKERMAN, G.; EL HASSAN, H.; LI, J.; RICHARDS, J. C.; TOMMASSEN, J.; VAN DER LEY, P. Identification of a Novel Lipopolysaccharide Core Biosynthesis Gene Cluster in Bordetella pertussis, and Influence of Core Structure and Lipid A Glucosamine Substitution on Endotoxic Activity. Infection and Immunity, v. 77, p. 2602-2611, 2009.

GEURTSEN, J.; STEEGHS, L.; HAMSTRA, H. J.; TEN HOVE, J.; DE HAAN, A.; KUIPERS, B.; TOMMASSEN, J.; VAN DER LEY, P. Expression of the lipopolysaccharide-modifying enzymes PagP and PagL modulates the endotoxic activity of Bordetella pertussis. Infect. Immun., v. 74, p. 5574-5585, 2006.

GLENNY, A. T.; POPE, C. G.; WADDINGTON, H.; WALLACE, U. Immunological notes. XXII. The antigenic value of toxoid precipitated by potassium alum. The Journal of Pathology and Bacteriology, v. 29, p. 38-45, 1926.

GUPTA, R. K.; RELYVELD, E. H.; LINDBLAD, E. B.; BIZZINI, B.; BEN-EFRAIM, S.; GUPTA, C. K. Adjuvants - a balance between toxicity and adjuvanticity. Vaccine, v. 11, p. 293-306, 1993.

GUPTA, R. K.; SIBER, G. R. Adjuvant for human vaccines- current status, problems and future prospects. Vaccine, v. 13, p. 1263-1276, 1995. 
HENDRIKSEN, C. F. M. Laboratory animals in vaccine production and control replacement, reduction and refinement. Boston, USA: Kluwer Academic Publishers, 1988.

HIGASHI, H. G.; LUNA, E.; PRECIOSO, A. R.; VILELA, M.; KUBRUSLY, F. S.; DIAS, W. O.; RAW, I. Acellular and "Low" Pertussis Vaccines: Adverse events and the role of mutations. Rev. Inst. Med. Trop., v. 51, p. 131-134, 2009.

HILLEMAN, M. R. Critical appraisal of emulsified oil adjuvants applied to viral vaccine. Progress in Medical Virology, v. 8, p. 131-182, 1966.

HILLEMAN, M. R. Vaccines in historic evolution and perspective: a narrative of vaccines discoveries. Vaccine, v. 18, p. 1436-1447, 2000.

HOMMA, J. Y.; MATSURA, M.; KANEGASAKI, S.; KAWAKUBO, Y.; KOJIMA, Y.; SHIBUKAWA, N.; KUMAZAWA, Y.; YAMAMOTO, A.; TANAMOTO, K.; YASUDA, T.; IMOTO, M.; YOSHIMURA, H.; KUSUMOTO, S.; SHIBA, T. Structural Requirements of Lipid A Responsible for the Functions: A Study with Chemically Synthesized Lipid A and Its Analogues. Biochemistry, v. 98, p. 395-406, 1985.

HOPKINS, M. Imunização. In: Imunologia. South Carolina, USA: University of South Carolina, 2009. Cap. 14. Disponível em: http://pathmicro.med.sc.edu/portuguese/immuno-port-chapter14.htm. Acesso em: 19 dez. 2010.

INVIVOGEN INSIGHT. Agonistic \& Antagonistic Effects of LPS on TLR4. San Diego, California, USA. Maio, Junho, 2007. Disponível em: http://www.invivogen.com/docs/Insight200705.pdf. Acesso em: 15 set. 2010.

KOVACSOVICS-BANKOWSKI, M.; CLARK, K.; BENACERRAF, B.; ROCK, K. L. Efficient major histocompatibility complex class I presentation of exogenous antigen upon phagocytosis by macrophages. Proc. Natl. Acad. Sci., v. 90, p. 4942-4946, 1993.

LE DUR, A.; CHABY, R.; SZABO, L. Isolation of Two Protein-Free and Chemically Different Lipopolysaccharides from Bordetella pertussis Phenol-Extracted Endotoxin. Journal of Bacteriology, v. 143, p. 78-88, 1980. 
LEE, C. H.; TSAI, C. M. Quantification of Bacterial Lipopolysaccharides by the Purpald Assay: Measuring Formaldehyde Generated from 2-keto-3-deoxyoctonate and Heptose at the Inner Core by Periodate Oxidation. Analytical Biochemistry, v. 267, p. $161-168,1999$.

LEIVE, L.; SHOVLIN, V. Physical, Chemical, and Immunological Properties of Lipopolysaccharide Released from Escherichia coli by ethylenediaminetetraacetate. The Journal of Biological Chemistry, v. 243, n. 24, p. 6384-6491, 1968.

LE MOIGNIC, D.; PINOY, E. Les vaccins en emulsion dans les corps gras ou "lipovaccins". Comp. Rend. Soc. Biol., v. 79, p. 201-203, 1916.

LIMA, M. G. S. Uso de óleos vegetais como adjuvantes da resposta imunológica em procedimentos de imunização. Departamento de Bioquímica e Biologia molecular. Disponível em:

http://64.233.169.104/search?q=cache:jqM2WE1K04J:sbbq.iq.usp.br/arquivos/region al/2002/cdresumo/palestras/028.pdf+sbbq.iq.usp.br/arquivos/regional/2002/cdresum o/palestras/028.pdf\&hl=pt-BR\&ct=clnk\&cd=1\&gl=br. Acesso em: 15 mar. 2010.

MACKICHAN, M. L.; SINGH, M. Recent developments in adjuvants for vaccines against infectious diseases. Biomolecular Engineering, v. 18, p. 69-85, 2001.

MARQUES, J. C. TLC - Cromatografia de camada delgada. Química Analítica. Universidade da Madeira, 2009.2 Disponível em: www3.uma.pt/jcmarques/research.htm. Acesso em: 13 maio 2010.

MARR, N.; HAJJAR, A. M.; SHAH, N. R.; NOVIKOV, A.; YAM, C. S.; CAROFF, M; FERNANDEZ, R. C. Substitution of the Bordetella pertussis Lipid A phosphate groups with glucosamine is required for robust NF-kB activation and release of proinflammatory cytokines in cells expressing Human but not Murine Toll-Like Receptor 4-MD-2-CD14. Infection and Immunity, v. 78, p. 2060-2069, 2010.

MARR, N.; TIRSOAGA, A.; BLANOT, D.; FERNANDEZ, R.; CAROFF, M. Glucosamine found as a substituent of both phosphate groups in Bordetella pertussis lipid A backbones: role of a BvgAS-activated ArnT ortholog. Journal of Bacteriology, p. 4281-4290, 2008.

MARTINS, R. M.; BENSABATH, G.; ARRAES, L. C.; OLIVEIRA, M. L. A.; MIGUEL, J. C.; BARBOSA, G. G.; CAMACHO, L. A. B. Multicenter Study on the Immunogenicity and Safety of Two Recombinant Vaccines Against Hepatitis B. Mem Inst. Oswaldo Cruz, v. 99, n. 8, p. 865-871, 2004. 
MATA-HARO V.; CEKIC C.; MARTIN M.; CHILTON, P. M; CASELLA, C. R.; MITCHELL, T. C. The Vaccine Adjuvant Monophosphoryl Lipid A as a TRIF-Biased Agonist of TLR4. Science, v. 316, 2007.

METZ, B.; HENDRIKSEN, C. F. M.; JISKOOT, W.; KERSTEN, G. F. A. Reduction of animal use in human vaccine quality control: opportunities and problems. Vaccine, v. 20, p. 2411-2430, 2002.

MIYAKI, C.; QUINTILIO, W.; MIYAJI, E. N.; BOTOSSO, V. F.; KUBRUSLY, F. S.; SANTOS, F. L.; IOURTOV, D.; HIGASHI, H. G.; RAW, I. Production of H5N1 (NIBRG-14) inactivated whole virus and split virion influenza vaccines and analysis of immunogenicity in mice using different adjuvant formulations. Vaccine, v. 28, p. 2505-2559, 2010.

MORALES, R. P. Ensayo del lisado de amebócitos del Limulus (LAL). Rev. Cub. Farm. v. 38, n.1, p.1-1, 2004.

MORRISON, D. C.; BETZ, S. J.; JACOBS, D. M. Isolation of a Lipid A bound polypeptide responsible for "LPS-initiated" mitogenesis of $\mathrm{C}_{3} \mathrm{H} / \mathrm{HeJ}$ spleen cells. Journal of Experimental Medicine, v. 144, p. 840-846, 1976.

MOTA, E. F.; LIMA, M. G. S.; MELO, D. F. Adjuvantes imunológicos: avanços e perspectivas. Ciência Animal, v. 16, n. 2, p. 79-88, 2006.

MURRAY, R.; COHEN, P.; HARDEGREE, M. C. Mineral oil adjuvants: biological and chemical studies. Ann. Allerg. v. 30, p. 146-151, 1972.

O'HAGAN, D. T. Vaccine adjuvants: Preparation Methods and Research Protocols. New Jersey, USA: Humana Press, 2000. v. 42. cap. 16.

O'HAGAN, D. T.; MACKICHAN, M. L.; SINGH, M. Recent developments in adjuvants for vaccines against infectious diseases. Biomolecular Engineering, v. 18, p. 69-85, 2001.

O'HAGAN, D. T.; SINGH, M.; GUPTA, R. K. Poly(lactide-co-glycolide) microparticles for the development of single-dose controlled-release vaccines. Adv. Drug Del. Rev. v. 32, p. 225-246, 1998.

OGRA, P. L.; FADEN, H.; WELLIVER, R. C. Vaccination strategies for mucosal immune responses. Clin. Microb., v. 14, p. 430-445, 2001. 
OKEMOTO, K.; KAWASAKI, K.; HANADA, K.; MIURA, M.; NISHIJIMA, M. A potent adjuvant monophosphoryl lipid $A$ triggers various immune responses, but not secretion of IL-1beta or activation of caspase-1. J. Immunol., v. 176, p. 1203-1208, 2006.

PASHINE, A.; VALIANTE, N. M.; ULMER, J. B. Targeting the innate immune response with improved vaccine adjuvants. Nature Medicine, v. 11, n. 4, 2005.

PATIL, P. K.; BAYRY, J.; RAMAKRISHNA, C.; HUGAR, B.; MISRA, L. D.; NATARAJAN, C. Immune response of goats against foot-and-mouth disease quadrivalent vaccine: comparison of double oil emulsion and aluminium hydroxide gel vaccines in eliciting immunity. Vaccine, v. 20, p. 2781-2789, 2002.

QUINTILIO, W.; KUBRUSLY, F. S.; IOURTOV, D.; MIYAKI, C.; SAKAUCHI, M. A.; LUCIO, F.; DIAS, S. C.; TAKATA, C. S.; MIYAJI, E. N.; HIGASHI, H. G.; LEITE, L. C. C.; RAW, I. Bordetella pertussis monophosphoryl lipid A as adjuvant for inactivated split virion influenza vaccine in mice. Vaccine, v. 27, p. 4219-4224, 2009.

RAMON, G. Procedes pour accroitre la production des antitoxines. Annales de Institut Pasteur, v. 40, p. 1-10, 1926.

RAMON, G. Sur l'augmentation anormale de l'antitoxine chez les chevaux producteurs de serum antidipherique. Bull. Soc. Cent. Med. Vet., v. 101, p. 227-234, 1925.

RAW I. Biotecnologia e saúde pública. Revista USP, v. 75, p. 6-17, 2007.

RIETSCHEL, E. T.; BRADE, H.; BRADE, L.; BRANDENBURG, K.; SCHADE, U.; SEYDEL, U.; ZÄHRINGER, U.; GALANOS, C.; LÜDERITZ, O.; WESTPHAL, O. Lipid $A$, the endotoxic center of bacterial lipopolysaccharides: relation of chemical structure to biological activity. Prog Clin Biol Res., v. 231, p. 25-53, 1994.

ROUSER, G.; FLEISHER, S.; YAMAMOTO, A. Two dimensional thin layer chromatographic separation of polar lipids and determination of phospholipids by phosphorous analysis of spots. Lipids, v. 5, p. 494-496, 1970.

SALKOWSKI, C. A.; DETORE, G. R.; VOGEL, S. N. Lipopolysaccharide and monophosphoryl lipid A differentially regulate interleukin-12, gamma interferon, and interleukin-10 mRNA production in murine macrophages. Infect. Immun., v. 65, p. 3239-3247, 1997. 
SESARDIC, D.; DOBBELAER, R. European union regulatory developments for new vaccine adjuvants and delivery systems. Vaccine, v. 22, p. 2452-2456, 2004.

SHEPARD, C. W.; SIMARD, E. P.; FINELLI, L.; FIORE, A. E.; BELL, B. P. Hepatitis $B$ virus infection: epidemiology and vaccination. Epidemiol Rev., v. 28, p. 112-125, 2006.

SINGH, M.; O'HAGAN, D. T. Recent Advances in Vaccine Adjuvants. Pharmaceutical Research, v. 19, n. 6, 2002.

TAKAYAMA, K.; RIBI, E.; CANTRELL, J. L. Isolation of a nontoxic lipid A fraction containing tumor regression activity. Cancer Res., v. 41, p. 2654-2657, 1981.

THE UNITED STATES PHARMACOPEIA CONVENTION. Biological tests and assays: Pyrogen Test. In: , 2006. v. 1. cap. 151, p. 135-136. Disponível em:http://www.anvisa.gov.br/reblas/bio/anali/analitico_008.htm. Acesso em: 15 out. 2010.

THOELEN, S.; DE CLERCQ, N.; TORNIEPORTH, N. A prophylactic hepatitis B vaccine with a novel adjuvant system. Vaccine, v. 21, p. 2400-2403, 2001.

THOELEN, S.; VAN DAMME, P.; MATHEI, C.; LEROUX-ROELS, G.; DESOMBERE, I.; SAFARY, A.; VANDEPAPELIERE, P.; SLAOUI, M.; MEHEUS, A. Safety and immunogenicity of a hepatitis $B$ vaccine formulated with a novel adjuvant system. Vaccine, v. 16, p. 708-714, 1998.

TIRSOAGA, A.; EL HAMIDI, A.; PERRY, M. B.; CAROFF, M.; NOVIKOV, A. A rapid, small-scale procedure for the structural characterization of lipid $A$ applied to Citrobacter and Bordetella strains: discovery of a new structural element. J Lipid Res., v. 48, p. 2419-2427, 2007.

VERHEUL A, F. M.; SNIPPE, H.; POOLMAN, J. T. Meningococcal lipopolysaccharides: virulence factor and potencial vaccine component. Microbiol. Rev., v. 57, p. 34-49, 1993.

WORLD HEALTH ORGANIZATION. Introduction of hepatitis B vaccine into childhood immunization services Management guidelines, including information for health workers and parents. Department of Vaccines and Biologicals. Geneva, Switzerland, 2001. Disponível em:

www.who.int/vaccines-documents/. Acesso em: 03 fev. 2011. 